Marcos Costa Valadares

\title{
Avaliação comparativa do potencial miogênico de células tronco mesenquimais adultas obtidas de diferentes fontes
}

Tese apresentada ao Instituto de Biociências da Universidade de São Paulo, para a obtenção de Título de Doutor em Ciências, na Área de BIOLOGIA/GENÉTICA.

Orientadora: Mayana Zatz

São Paulo 


\section{Ficha Catalográfica}

Valadares, Marcos Costa

Avaliação comparativa do potencial miogênico de células tronco mesenquimais adultas obtidas de diferentes fontes

Número de páginas: 122

Tese (Doutorado Direto) - Instituto de Biociências da Universidade de São Paulo. Departamento de Genética e Biologia Evolutiva.

1. Distrofia Muscular

2. Células-tronco Mesenquimais

3. Pericito

I. Universidade de São Paulo. Instituto de Biociências. Departamento de Genética e Biologia Evolutiva

Comissão Julgadora:

$\operatorname{Prof}(\mathrm{a}) . \operatorname{Dr}(\mathrm{a})$.

$\operatorname{Prof(a).~Dr(a).~}$
$\operatorname{Prof}(\mathrm{a}) . \operatorname{Dr}(\mathrm{a})$.

Prof(a). Dr(a).

Prof(a). Dr(a). Mayana Zatz 


\section{Dedicatória}

Dedico esta tese à Deus por sua infinita graça e misericórdia, à minha família pelo apoio e carinho, à minha esposa pela paciência e dedicação e ao corpo de Cristo, igreja amada, por demonstrar o amor incondicional de Cristo pela minha vida. 


\section{Epígrafe}

"É gosto pervertido satisfazer-se com a mediocridade quando ótimo está ao seu alcance."

(Isaac D’Israeli) 


\section{Agradecimentos}

Essa tese é a compilação de muito trabalho e dedicação que só foi possível devido a ajuda de muitas pessoas, às quais sou muito grato. Por cada contribuição oferecida, deixo aqui o meu mais profundo reconhecimento.

À Deus, pelo amor e misericórdia demonstrada todos os dias perdoando os meus pecados pelo sangue de Jesus e pela esperança da vida eterna.

Aos meus pais, Cláudio e Dalma, pelos ensinamentos preciosos, carinho, suporte, incentivo e fé que me trouxeram até onde estou e me ajudaram a entender o mundo. Eu amo vocês demais!

À minha amada e virtuosa mulher Agnes, que esteve ao meu lado por todos os momentos me ajudando a passar e a conquistar essa vitória. Essa tese é tão sua quanto minha e minha alegria é viver com você até a volta de Jesus. Te amo muito, linda.

Às minhas irmãs, Nivinha e Cacá, por serem tão companheiras e amigas. Não poderia ter tido melhores irmãs e certamente não seria o mesmo sem vocês. Amo vocês.

Aos meus cunhados, Anderson e Rony, por serem servos do Deus vivo e os irmãos que eu não tive, compartilhando alegrias e experiências em todos os momentos.

À Clarinha, minha adorável e linda sobrinha, que nos alegra com cada palavra e atitude da sua recente existência.

Aos meus avós, tios e tias e primos que com tanta alegria nos contagiam nas festas, encontros, visitas e conversas pelo whatsapp! Certamente fui privilegiado por ter uma família tão feliz e abençoada.

Aos meus sogros, Glleno e Tereza, e cunhado, Bruno, por terem tão amorosamente me recebido em sua família. É um prazer ser parte da família de vocês e poder compartilhar mais esse momento de alegria.

Aos pastores Ubirajara, Eduardo Campos e Gerson Tadakuma e suas respectivas famílias que guardo em meu coração. Em todos os momentos, desde que me mudei para São Paulo me ajudaram e ensinaram grandes coisas.

Aos amados irmãos da igreja de Sumaré que sempre oraram por mim e me acolheram como um verdadeiro irmão em Cristo. Realmente conheço o significado 
de pertencer a uma família em Cristo. Seria impossível listar todos que contribuíram com essa conquista, mas sei que Deus não se esquecerá de nenhum de vocês. Sou feliz por ser parte deste corpo que em breve verá Jesus.

Aos amigos que tive a felicidade de encontrar na graduação Gustavo "Chefe", Thiago Alegria, Felipe "CPF", Leonardo "Leocócito", Juliana "Pelúcia". Amigos realmente diferentes, presentes de Deus. Vocês são especiais demais!

Ao Di, Dé e Alexandre e Xurros, que entraram no final dessa etapa, mas já influenciam tanto com projetos em comum!

Gostaria de citar uma amiga nessa parte:

"No decorrer da vida científica aprendemos que a execução de ideias depende fundamentalmente do trabalho em equipe. No meu caso, além do trabalho em equipe, eu tive a sorte de fazer AMIGOS. Por isso, agradeço imensamente e divido essa conquista e alegria com todos vocês"

Mariane Secco, 2011

À Dra. Mayana Zatz, por abrir as portas para este mundo tão intenso e empolgante da ciência e permitir o meu crescimento dentro do laboratório. Professora, sou muito grato pelos conselhos e conversas que permitiram enxergar novas possiblidades e abrir novos horizontes. Muito obrigado pela oportunidade. Deus te abençoe por isso.

À Tati, por ter paciência de tolerar meus erros de iniciante e mania de limpeza. Desculpe os problemas causados e obrigado por me ajudar tanto, Tati. Realmente pude aprender muito com você

À Nati, por ajudar a entender que na ciência nem tudo é tão fácil quanto parece. Nati, obrigado por me ajudar a moldar minha visão das coisas. Levarei isso comigo.

Ao Éder, pelo empenho e organização. Muito obrigado por esses anos de companheirismo no lab.

À Mari, por sempre ter a certeza de que tudo vai dar certo e trabalhar duro para que isso aconteça. Mari, você é uma pessoal muito especial e diferente que me ensina muito. Sou grato pelas risadas e incentivos tão pertinentes! Deus te abençoe.

Ao Carmão, por me ajudar a exercer meu senso crítico e crescer como cientista! Muito Obrigado por tudo meu amigo.

À Heloísa Caetano, por compartilhar tanto da fé em Jesus quanto do prazer na ciência! Deus te abençoe, Helô!

Às minhas amigas que com muita alegria convivia diariamente e que tanto 
me ajudaram em todos esses anos, tantas vezes com trabalhos manuais e físicos exaustivos até altas horas da noite. São elas:

À Amanda, pelas perguntas simples e ao mesmo tempo totalmente pertinentes que nos faziam pensar. Muito obrigado, Amandita

À Gabi, por se dedicar junto ao projeto e permitir que eu aprendesse a ensinar um pouquinho. Desculpe as minhas falhas, Gabi. Te desejo toda a sorte na sua caminhada.

À Giu, que chegou à pouco tempo, mas já mostrou tanto empenho e dedicação. Você é uma guerreira que inspira! Deus te abençoe.

À Juba, que é tão dedicada quanto inteligente (MUITO). Juba, você tem um futuro brilhante e foi muito bom compartilhar esse tempo com você! Muito Obrigado!

À Mayra, que é uma quase-irmã! Mayra, obrigado pelas piadas e brincadeiras (e bolos - fala pra sua Mãe!) e por seu apoio em todos esses anos! Alegrias em dobro pra você!

À Miriam, que com menos de um ano (rapidamente) fez diferença. Miriam, muito obrigado pela perspectiva científica que você trouxe junto com você.

À Nane e a Naila, que sabem fazer ciência e ajudam no nosso crescimento (e não estou falando do power jump! lalala). Meus mais sinceros agradecimentos.

Ao Michel que contribuiu muito com sua intelectualidade. Valeu Michael!

À Inês, Melinda, Bárbara, Thiago e Toninha por apoiarem as mudanças positivas e contribuírem com elas.

Aos colegas do laboratório da 211 e a Dra. Maria Rita por suas contribuições. Em especial à Larissa, pelas horas de dedicação no FACS.

À professora Mariz e seus queridos alunos que tanto nos querem bem e participam conosco das angústias e alegrias de se fazer ciência!

Ao Professor Keith e seus alunos que também são companheiros de duras batalhas e muito nos ajudam.

Ao Peter Pearson, pelas conversas científicas.

À todos amigos, professores e funcionários do Genoma e do IB que certamente compõe esse cenário. Em especial queria agradecer:

À Vanessa, Cons, Luciana e Wagner pela valiosa ajuda com tudo.

À Márcia, pela companhia nos almoços na copa

Ao Fernando pela alegria e zelo. 
À Martinha, por todos os cortes, colorações e imunos que foram feitas com dedicação. Muito obrigado

Às meninas do diagnóstico: Meire, Monize, Vanessa e Kátia por serem tão dispostas a ajudar.

Ao Roberto e Lilian, por sempre tornarem o nosso trabalho mais fácil e contribuírem tanto. Vcs são fera! preciosos.

À Helô, Rose, Viviam, Thaís e Érika por cuidar dos nossos modelos

Ao IPEN, em especial a Neidinha, pela colaboração e ajuda.

Aos porteiros que nos tratam tão bem.

Às moças da limpeza por nos ajudarem nessa parte tão importante. Em especial à Nete pelo carinho (e almoços!).

Aos colaboradores, Prof. Dr. Edmundo Baracat e Paulo Margarido, que tanto nos ajudaram na coleta dos nossos materiais possibilitando essa pesquisa.

Às doadoras que permitiram que nós fazermos essa pesquisa.

À Fapesp pelo apoio financeiro. 


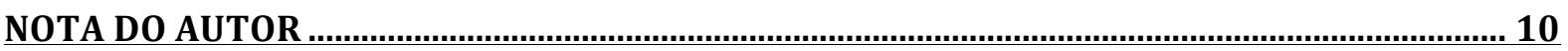

RESUMO

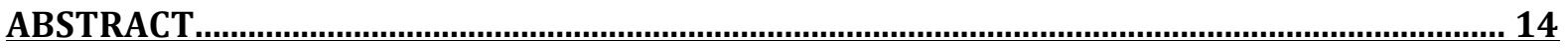

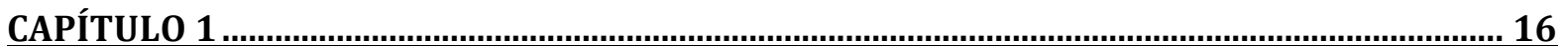

I - INTRODUÇÃO GERAL 16

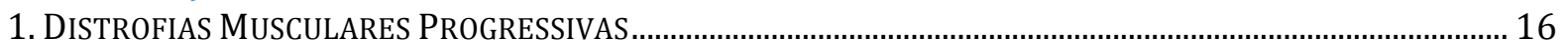

2 - DESENVOLVIMENTO, DEGENERAÇÃO E REGENERAÇÃo MUSCULAR …………………….............................. 20

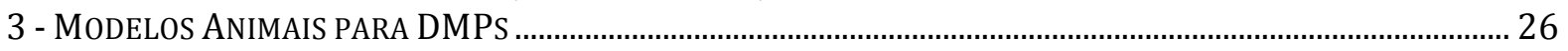

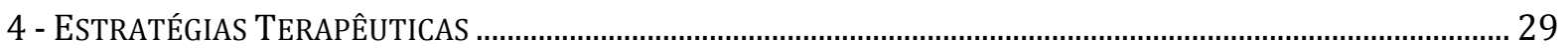

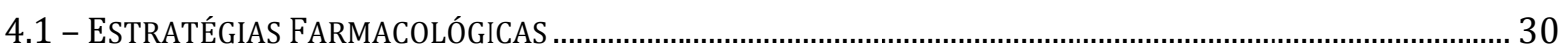

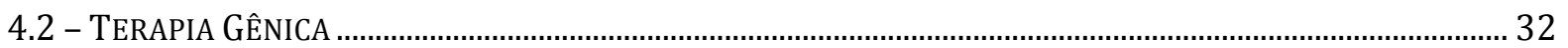

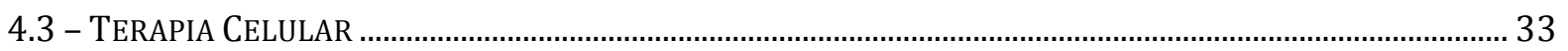

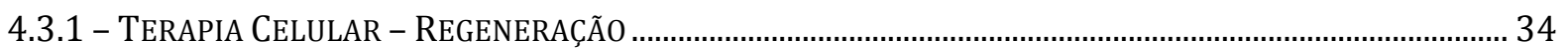

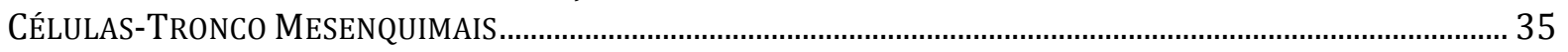

4.3.2 - TERAPIA CELULAR - ModULAÇão (EFEITO PARÁCRINO) ………………………….............................. 42

III - OBJETIVOS

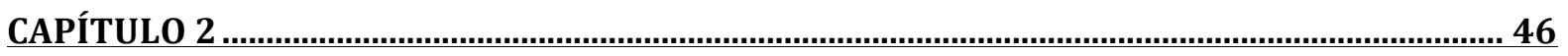

I - ISOLAMENTO DE CÉLULAS-TRONCO MESENQUIMAIS DE TECIDOS DIFERENTES ATRAVÉS DE MÉTODOS CLÁSSICOS

II - MÉTODOS PARA CARACTERIZAÇÃo IN VITRO

III - RESULTADOS $r$

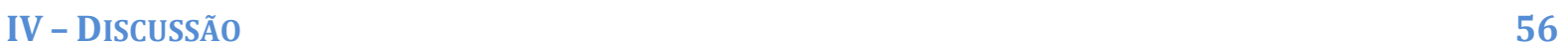

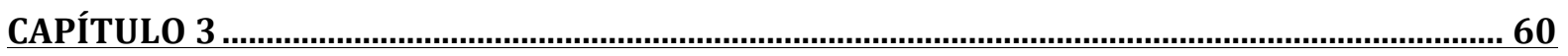

I - ISOLAMENTO DE CÉLULAS ATRAVÉS DE FACS 60

II- MATERIAL E MÉtodos $\quad 62$

III - RESULTADOS $\quad 63$

IV - DISCUSSÃo 164

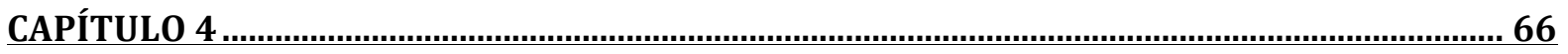

I - ISOLAMENTO DE CÉLULAS DE PERICITO

$\begin{array}{lr}\text { II- MATERIAL E MÉTODOS } & 71\end{array}$

$\begin{array}{lr}\text { III - RESULTADOS } & 77\end{array}$

$\begin{array}{lr}\text { VI - DISCUSSÃo } & 85\end{array}$

CAPÍTULO 5

$\begin{array}{ll}\text { I - DISCUSSÃO GERAL } & 94 .\end{array}$

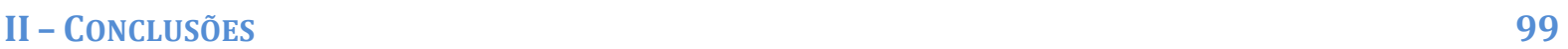

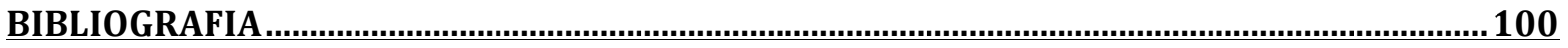

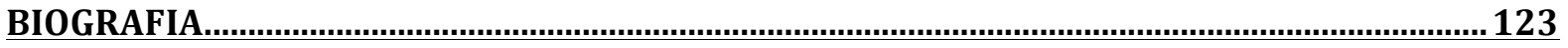




\section{Nota do Autor}

Esse trabalho se propôs a comparar o potencial miogênico de células-tronco mesenquimais - CTMs (MSCs - do inglês Mesenchymal Stem Cells) de diferentes fontes de tecido adulto.

Esta tese está organizada em capítulos, sendo o primeiro deles um introdução geral e atualizada dos temas que compreendem essa tese (Capítulo 1). Nos próximos capítulos, os leitores serão levados a realidade do desenvolvimento do projeto no transcorrer dos anos até a formulação dessa tese. No último capítulo (Capítulo 5) será feita uma discussão crítica geral dos resultados tendo como perspectiva as abordagens e técnicas usadas para a avaliação de cada dado.

A primeira etapa do nosso estudo foi a definição de quais células seriam usadas para comparação e quais protocolos usaríamos para descrever o potencial miogênico das células (Capítulo 2). Dentro desse mesmo capítulo levantaremos as implicações derivadas das nossas definições e uma análise crítica dos resultados parciais.

No próximo passo (Capítulo 3) descrevemos a introdução no projeto de uma técnica (FACS - do inglês Fluorescent Activates Cell Sorter) muito importante na continuidade dessa investigação científica que nos permitiu avaliar populações específicas dentro de uma cultura de células heterogêneas e as populações escolhidas para avaliação. 
Em sequência (Capítulo 4) argumentamos a escolha do tipo células e seus marcadores com seus respectivos resultados de testes in vitro e in vivo.

Por fim (Capítulo 5) faremos a discussão contextualizada e crítica a respeito das implicações válidas dos desafios propostos, bem como das limitações existentes neste projeto.

Como pesquisador é um privilégio poder trabalhar na linha de frente na busca por terapias para pacientes que tanto sofrem com doenças graves como é o caso das Distrofias Musculares Progressivas (DMPs). Porém não podemos deixar de considerar que uma terapia desse calibre e extensão não se tornará realidade em um único projeto de poucos anos. São muitos os detalhes de uma terapia que representam um impacto enorme para o tratamento de indivíduos. Tendo isso em mente, nesse projeto tivemos a oportunidade de endereçar alguns destes aspectos sob uma perspectiva criteriosa do real impacto que isso pode trazer para pacientes. Assim, esperamos ter contribuído com uma pequena parte, como um tijolo, na construção desse grande edifício do conhecimento que ansiamos, um dia, trazer a solução para problemas até hoje insolúveis. 


\section{Resumo}

As Distrofias Musculares Progressivas (DMPs) constituem um grupo de doenças genéticas caracterizadas por uma degeneração progressiva e irreversível da musculatura esquelética. Dentre as diferentes abordagens terapêuticas propostas para esse grupo de doenças, a terapia celular com células-tronco mesenquimais (CTMs) tem sido um foco importante de pesquisas. Muitos tipos de CTMs já foram descritas com o intuito de reconhecer qual o tipo ideal a ser usado em uma possível terapia celular para DMPs. Neste trabalho comparamos o potencial terapêutico de células-tronco de diferentes fontes obtidas de um mesmo doador. Escolhemos as células de pericito (CP) como ferramenta de estudo, uma vez que elas estão presentes em todos os tecidos irrigados por vasculatura. Isolamos pericitos de 4 tecidos da mesma doadora (endométrio, trompa, tecido adiposo e músculo). Em seguida, injetamos 1 milhão dessas células intraperitonialmente em camundongos Utrn ${ }^{\text {tm1Ked }} D m d^{m d x} / J$ (duplo knockout para o gene da distrofina e utrofina) semanalmente, por 8 semanas, e avaliamos a clínica e a sobrevida desses animais. Observamos que nas condições experimentais desse estudo, o potencial miogênico dessas células é insuficiente para ser utilizado como terapia regenerativa. Entretanto, apesar dos testes padronizados não detectarem nenhuma melhora clínica aparente, os animais tratado com pericitos de gordura mostraram uma curva de sobrevivência significativamente maior do que os controles não tratados. Como não houve diferenciação miogênica, esses resultados sugerem que os efeitos benéficos ocorreram através de liberação de fatores tróficos e imunoreguladores (efeito parácrino). É digno de nota que apesar das células serem todas derivadas de pericito e de uma mesma doadora o aumento de sobrevida só foi 
observado com células do tecido adiposo. Esses resultados indicam que o potencial terapêutico de CP difere de acordo com sua origem e que essa diferença não depende do genoma do doador. Esses resultados constituem um passo inicial, porém, valioso na compreensão do potencial de utilização dessas células em terapias. 
Progressive Muscular Disorders (PMDs) are a group of heterogeneous genetic diseases characterized by an irreversible degeneration of the muscle tissue due to mutation or absence of a protein. Among the many different available therapeutic approaches to treat PMDs, cell therapy using mesenchymal stem cells (MSCs) are one of the most studied ones. There are many types of MCSs described to date and the need to identify the best one suited to treat PMDs has yet to be addressed. In this thesis, we compared the therapeutic potential of different types of stem cells derived from the same donor. First, we chose pericytes as a tool of comparison, as this cell is unequivocally present in all vascularized tissues. We isolated pericytes of 4 different tissues from the same donor (endometrium, fallopian tubes, adipose tissue and muscle). We injected 1 million of these cells intraperitonially in $U t r n^{\text {tm1Ked }} D m d^{m d x} / J$ mice (knockout for the dystrophin and utrophin gene) weekly for 8 weeks evaluating the clinical features and survival curve of these mice. We observed that, in the experimental conditions of this study, the myogenic potential of these cells is insufficient to be harnessed as therapy for regenerative purposes. However, despite the fact that the standardized tests did not detect any apparent clinical improvement, mice treated with pericytes derived from adipose tissue had a survival curve greater than control treated mice. As we could not observe any myogenic differentiation or cell engraftment, this results suggests that the beneficial effect observed could be due to the releasing of trophic and immune modulator factors (paracrine effect). It is noteworthy that despite all cells being derived from the same donor, the increase in life expectancy was only observed in pericytes derived from the adipose tissue. These results indicate that the 
therapeutic potential of pericytes differs according to their tissue of origin and the difference is not due to genetic differences. This is still preliminary data but it is valuable in understanding the therapeutic potential of these cells. 


\section{Capítulo 1}

\section{I - Introdução Geral}

\section{Distrofias Musculares Progressivas}

As Distrofias Musculares Progressivas (DMPs) são um grupo clinica e geneticamente muito heterogêneo de doenças caracterizadas pela degeneração progressiva da musculatura. Já foram caracterizadas mais de 40 formas de $\mathrm{DMPs}^{6}$. que diferem quanto a idade do início, velocidade de progressão, músculos preferencialmente afetados e padrão de herança ${ }^{7}$ (Figura 1).

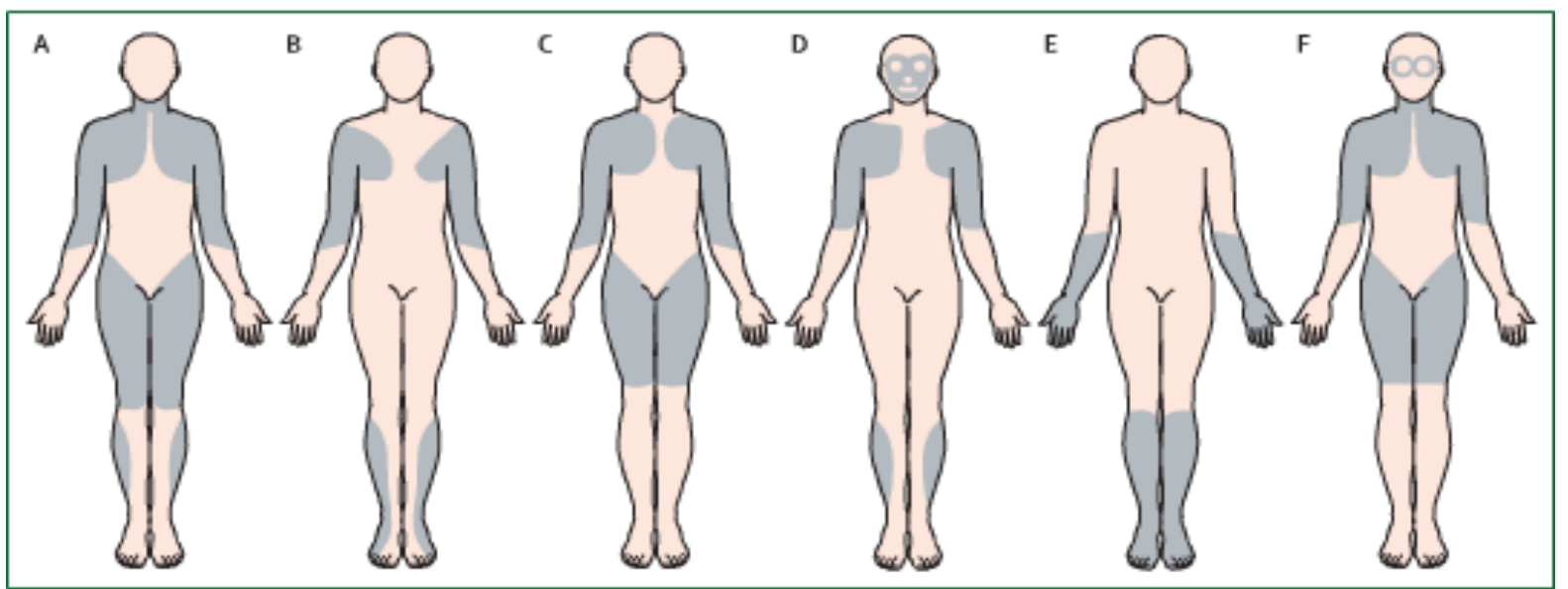

Figura 1: Imagem retirada de Emery, 2002. A, Duchenne e Becker; B, Emery-Dreifuss; C, Cinturas; D, facioscapulohumeral; E, distal, F, oculofaringeal. Áreas sombreadas = áreas afetadas

A grande maioria das DMPs resultam de mutações em genes que codificam proteínas pertencentes à um complexo responsável pela estabilização da membrana celular, conhecido como DGC (Dystrophin-associated Glycoprotein Complex) $)^{8}$. Tanto a localização quanto a interação dessas proteínas tem sido objeto de ampla pesquisa (figura 2). A importância dessa estrutura no tecido muscular, 
baseia-se no fato que todo o sincício de células musculares comunica-se com a porção extracelular, sendo este 0 meio de transdução de sinais físicos ${ }^{9}$ e químicos $^{10}$. As mutações ou ausência das proteínas componentes deste complexo causam instabilidade à membrana citoplasmática, e, por conseguinte, aumentam os danos e as rupturas que as fibras musculares sofrem durante a contração muscular diante de insultos necessários para o desenvolvimento deste tecido. Acredita-se que neste cenário incia-se um ciclo crônico de regeneração e degeneração das fibras, no qual estão envolvidos muitos componentes, inclusive o sistema imune (mecanismos inflamatórios) ${ }^{11}$.

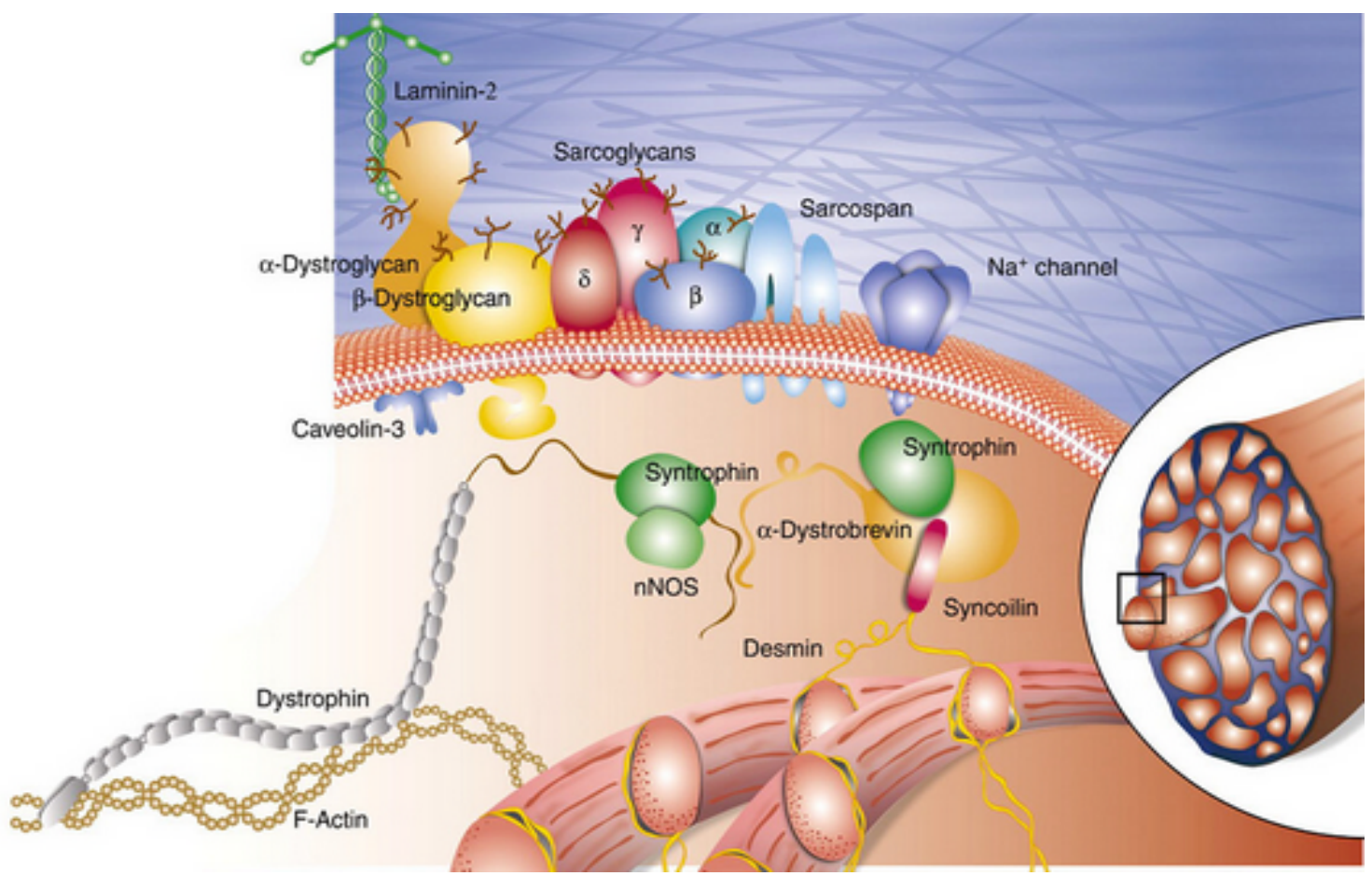

Figura 2: Complexo de proteínas que compões a DGC e outras proteínas associadas. (imagem retirada do site http://www.humgen.nl/)

\subsection{Distrofia Muscular de Duchenne}

A forma mais comum de distrofia muscular é a Distrofia Muscular de 
Duchenne (DMD), que afeta exclusivamente meninos com uma prevalência estimada de 1 caso a cada 3500 nascimentos ${ }^{12}$

Clinicamente pacientes com DMD não apresentam sintomas até os 3-5 anos de idade quando começam a ter dificuldades para se levantar, locomover, correr e subir escadas. Há um aumento sérico da proteína creatina quinase (CK), desde o nascimento indicativo de degeneração muscular. Pacientes geralmente apresentam hipertrofia da panturrilha e o confinamento à cadeira de rodas acontece entre os 1012 anos. Se não forem oferecidos cuidados especiais os pacientes, dificilmente sobrevivem após a terceira década ${ }^{13}$

O gene responsável pela DMD foi mapeado no braço curto do cromossomo $\mathrm{X}$ e também foi denominado DMD (do inglês Duchenne Muscular Dystrophy). É o maior gene humano descrito (2.5 milhões de pares de base, ou seja, quase $0,1 \%$ do genoma inteiro) e tem algumas isoformas ${ }^{14}$. A maior isoforma (figura 3), que é expressa no músculo esquelético, tem um RNAm de 14.000 pares de base e codifica uma proteína de 427 kDa com 3685 resíduos de aminoácidos ${ }^{12}$

A descoberta do gene e de seu produto proteico permitiu estudos mais profundos dos casos de DMD. Por exemplo, se observou que a Distrofia Muscular de Becker (DMB), dez vezes mais rara que a DMD, era uma forma alélica da última.

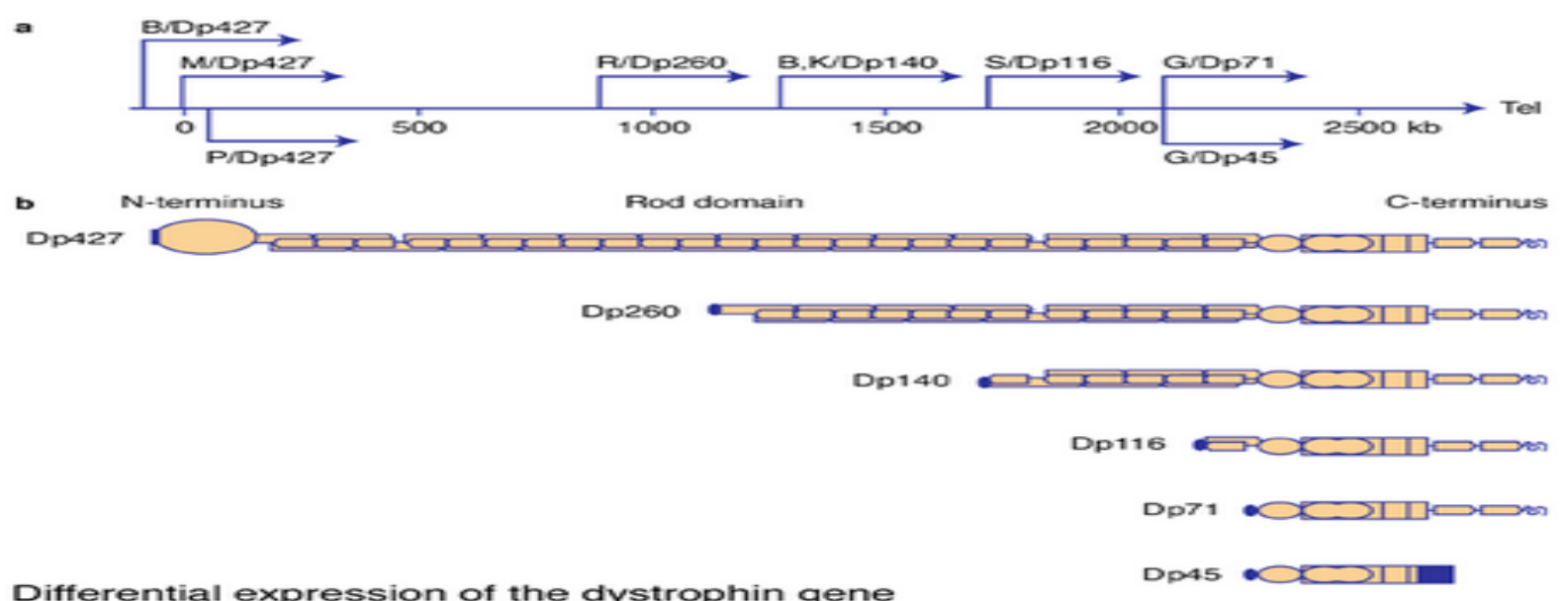


O curso clínico de pacientes com DMB é mais benigno mas muito variável mesmo em pacientes da mesma família. Os sintomas geralmente se iniciam na segunda ou terceira décadas mas em alguns pacientes só na fase adulta avançada.

Dentre os casos que causam DMD e DMB, 60\% são deleções, 5-6\% duplicações ou inversões e mutações de ponto compõe o restante dos casos. Quando deleções causam uma mudança no quadro de leitura do RNAm, a proteína resultante é instável e rapidamente degradada, comprometendo completamente sua função e resultando em quadros clínicos mais graves como de DMD. Já no caso de deleções em fase, uma versão de tamanho reduzido porém parcialmente funcional da proteína é produzida o que explica um quadro mais benigno. Além da mudança ou não do quadro leitura, as regiões da proteína que são deletadas também influenciam no curso da doença. Quando a deleção ou mutação ocorre no sítio de ligação ao complexo DGC (região $\mathrm{N}$ ou C-terminal) o quadro é geralmente mais grave. Já deleções em porções repetitivas, como o domínio bastão, estão associadas a quadros benignos. Foi descrito um paciente com mais de $50 \%$ da proteína deletada, mas com quadro benigno associado ${ }^{15}$.

A técnica de Western Blot (WB) permite avaliar a quantidade de distrofina em extratos proteicos com o uso de anticorpos que identificam a porção amino terminal, intermediária (conhecida como domínio bastão - do inglês rod domain) ou carboxiterminal $^{16}$. Em pacientes com DMD não se observa nenhuma proteína enquanto em pacientes com DMB pode haver uma quantidade reduzida ou uma proteína de tamanho diminuído. Já em cortes histológicos observamos, através de imunofluorescência, que algumas fibras de pacientes DMD podem ter marcação positiva para Distrofina, sem correlação com o fenótipo (chamadas fibras 
revertentes). Em DMB existe marcação positiva para distrofina, porém de forma diferente de um músculo normal ${ }^{15}$. De modo geral, há uma correlação entre quantidade de distrofina e gravidade do quadro clínico.

Desde a sua descoberta, o gene da DMD tem sido amplamente estudado. A relação da sua proteína codificante com os outros componentes desse sistema de transdução de sinal e de estabilização de membrana tem ajudado a entender como cada um dos componentes deste importante complexo atua em mecanismos patológicos ${ }^{17}$.

\section{2 - Desenvolvimento, Degeneração e Regeneração Muscular}

O músculo é um tecido pós-mitótico, ou seja, uma vez formado suas células não mais se dividem. Durante a fase embrionária, as células localizadas na parte dorsal dos somitos (estrutura segmentada derivada do mesoderma paraxial) originam, dentre outras estruturas, o dermomiótomo. Este, por sua vez, dá origem aos mioblastos embrionários que se fundem e formam as miofibras (miogênese). Essa também é a origem das células satélites(CS) ${ }^{18}$.

Estas células foram primeiramente identificadas em 1960 com localização periférica às fibras (por isso o nome satélite) porem abaixo da lâmina basal ${ }^{19}$. Posteriormente descobriu-se que essa população de células era a responsável pela regeneração muscular após o término do desenvolvimento embrionário ${ }^{20}$. A localização sub-laminar destas células promove um microambiente importante para um recrutamento rápido das mesmas numa situação de injúria ${ }^{21}$. Em 1986, demonstrou-se que fatores presentes em fibras musculares danificadas fazem com 
que as células satélites saiam de um estado quiescente natural e iniciem um processo de proliferação ${ }^{22}$. Posteriormente, através de transplantes de fibra única em músculos irradiados, notou-se que a CS possui uma capacidade de autorenovação comparável a uma célula-tronco. Transplantes de fibras com até 7 CSs foram suficientes para a geração de múltiplas fibras in vivo e ainda repovoaram o tecido transplantado gerando até 10 vezes mais células do que a quantidade inicialmente transplantada ${ }^{23}$. Em seguida, foi demonstrado que até mesmo o transplante de uma única célula foi suficiente para promover regeneração de fibras e repovoamento do nicho das $\mathrm{CSs}^{24}$. Desta forma, constatou-se que a CS, apesar de unipotente (capacidade de gerar apenas um tecido) é uma célula tronco pois tem potencial de renovação (gerar mais dela mesma) e diferenciação (gerar outro tipo celular).

A regeneração muscular é um processo complexo que pode ser divido em 3 fases sobrepostas ${ }^{21}:$ 1) resposta inflamatória; 2) ativação, diferenciação e fusão das CSs; e 3) maturação e remodelamento das novas fibras (figura 4).

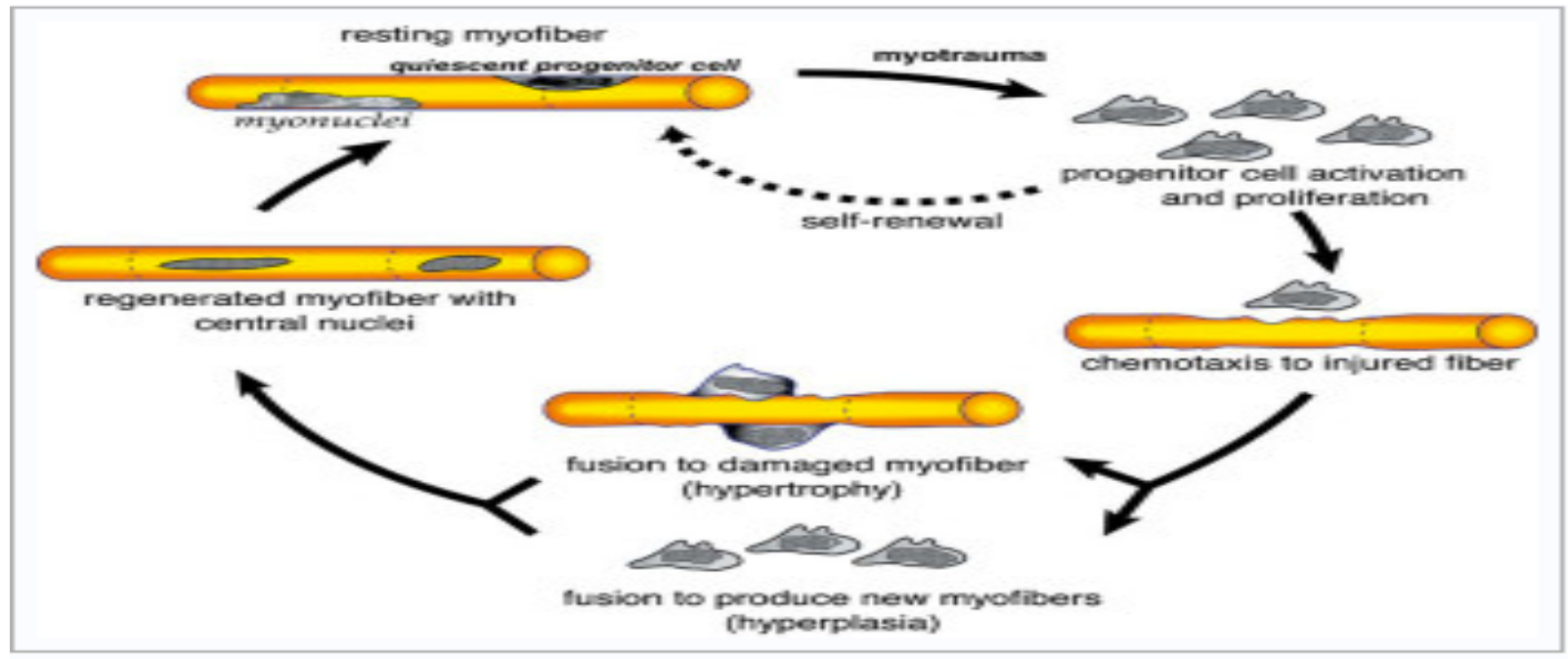

Figura 4: Representação do processo regenerativo do músculo. Imagem retirada do site http://pimm.wordpress.com/2007/02/08/satellite-cells-the-primary-stem-cells-of-adult-skeletalmuscle/ 
A degeneração muscular (derivada de um insulto mecânico ou químico) inicia-se com o aumento da permeabilidade ou até mesmo ruptura da membrana plasmática expondo moléculas que geralmente são restritas ao ambiente citosólico da fibra muscular (o que explica o aumento nos níveis séricos de proteínas como a creatina quinase e também de microRNAs músculo específicos ${ }^{25}$ ). Com isso, o sistema imune é ativado (atuação do sistema complemento ${ }^{21}$ ) e leucócitos são recrutados. Primeiramente, os neutrófilos infiltram o tecido, mas posteriormente macrófagos se tornam o tipo celular mais abundante. Duas populações de macrófagos parecem influenciar diretamente o tecido, sendo que a primeira, mais pró-inflamatória, fagocita restos celulares e a segunda, mais anti-inflamatória, facilita e induz a proliferação e diferenciação das células satélites ${ }^{26}$.

Após o recrutamento de células do sistema imunológico, ocorre um notável aumento da proliferação das CSs para recompor o músculo lesado. Pode-se observar que o simples bloqueio de divisão celular por colchicina ${ }^{27}$ ou irradiação ${ }^{28}$ é suficiente para diminuir drasticamente a regeneração muscular. Outros estudos ainda mostram que a proliferação das células satélites e suas células derivadas (mioblastos) é capaz de sustentar o crescimento e a regeneração muscular ${ }^{29}$. Depois de proliferarem, as células se fundem formando miotúbulos num processo similar, mas não idêntico, ao da embriogênese. As fibras regeneram em locais específicos de injúria e não num processo mais difuso ${ }^{30}$ podendo haver fusão completa, parcial (quando somente um dos lados das fibras se fundem, gerando bifurcação) ou nenhuma fusão ${ }^{31}$. No entanto, sabe-se que células satélites de outras fibras, até mesmo de outros músculos podem ser recrutadas e migrarem para o músculo lesado ${ }^{32}$. 
Histologicamente é possível observar que as fibras em regeneração apresentam variação nos calibres e núcleos na porção central. Ao final do processo de regeneração, os núcleos migram novamente para a periferia da fibra e se tornam indistinguíveis de fibras que não sofreram lesão. No caso das DMPs, o que se observa é um estado crônico deste ciclo de degeneração das fibras causadas pela instabilidade da membrana citosólica (por deficiência ou ausência completa de uma proteína) seguido do processo de regeneração (proliferação de CSs). Com o tempo, acredita-se que este reservatório de CSs do músculo vai se exaurindo, comprometendo o processo de regeneração das fibras ${ }^{33}$

Ao nível molecular, as células satélites podem ser definidas por uma série de marcadores que podem divergir entre espécies. Classicamente, as células satélites expressam o fator de transcrição Pax7 e Myf5. Em camundongos, o marcador CD34 também é utilizado para o isolamento de tais células ${ }^{34}$. Já em humanos, estudos apontam que células presentes no músculo que são CD34+ têm um potencial adipogênico associado. As células CD56+ seriam aquelas com o potencial estritamente miogênico e portanto as prováveis células satélites ${ }^{35}$. Após a ativação

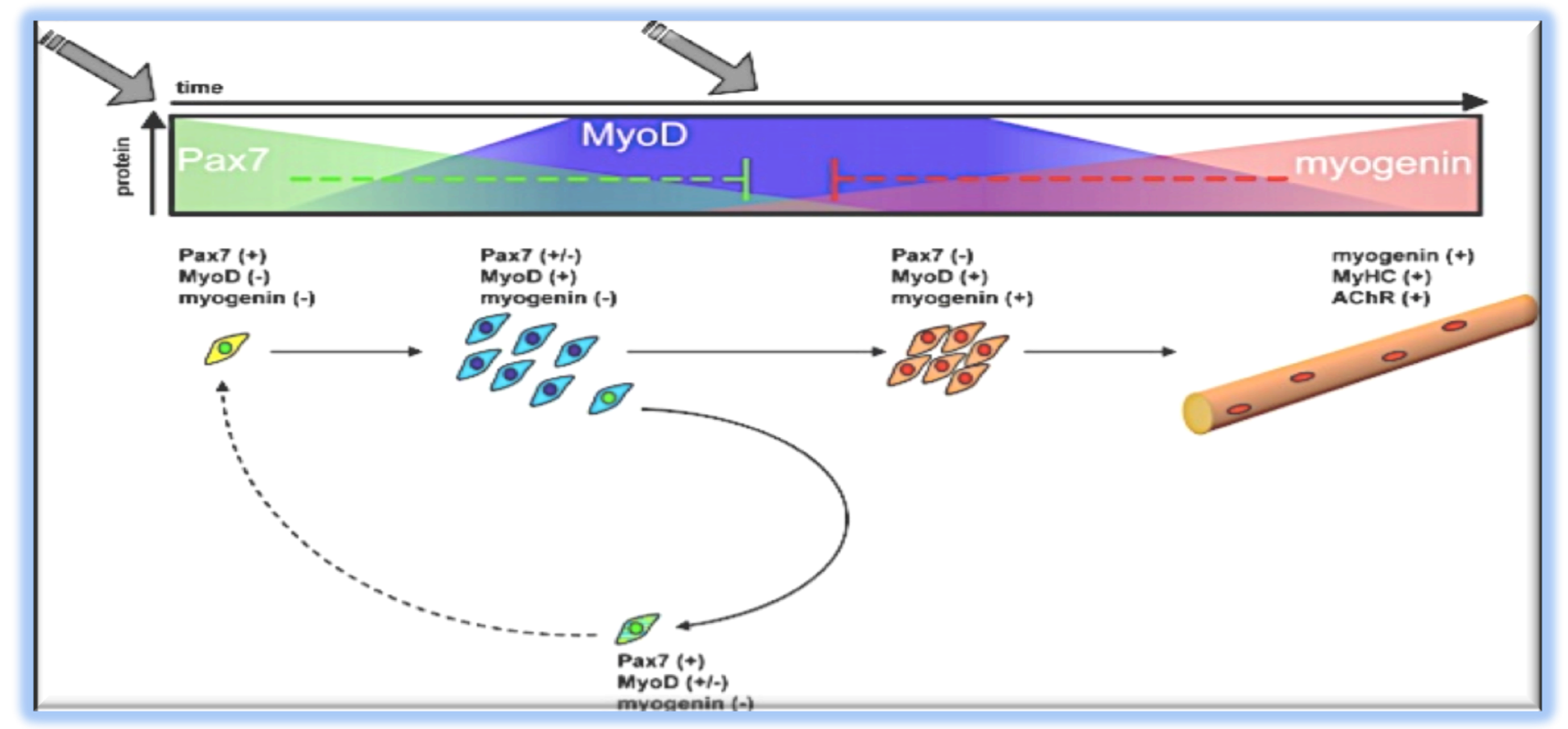

Figura 5: Expressão de marcadores durante o processo de diferenciação de uma CS (imagem modificada do site jcb.rupress.org) 
(saída do G0, estado de quiescência), o programa de diferenciação miogênica se inicia com o aumento de MyoD. Em até 48 horas, os fatores Myf5 e MyoD são coexpressos nessas células. A relação entre a expressão de Myf5 e MyoD em mioblastos distingue os mais propensos a diferenciação (quando MyoD é maior que Myf5) ou a proliferação (quando Myf5 maior do que MyoD). O início da diferenciação final se dá com a expressão dos fatores de transcrição miogenina e Mrf4 (também conhecido como Myf6) que coordenam a expressão de uma série de proteínas estruturais como a cadeia pesada da miosina, o marcador final de diferenciação miogênica ${ }^{36}$.

Nesse contexto de regeneração muscular, as CSs não são as únicas que tem uma participação importante. Cada vez mais tem se estudado outros tipos celulares que participam deste processo, seja como precursores miogênicos (em menor escala do que as CSs) como também células acessórias. Alguns grupos foram capazes de isolar e estudar células que estão presentes no músculo e que podem contribuir para a regeneração (direta ou indiretamente) num processo de injúria. Exemplos dessas células são:

Side Population Cells: Side Population Cells são células que quando incubadas com Hoechst 33342, excluem o corante (processo mediado pela proteína nuclear Abcg2) e formam uma população ligeiramente lateralizada quando visualizadas num gráfico de citometria (por isso o nome Side Population). Essas células foram capazes de gerar fibras musculares em camundongos distróficos ${ }^{37}$. Elas se localizam no interstício das fibras e portanto são precursores diferentes das CSs.

Células Intersticiais PW1+/Pax7-/CD34+/Sca1+ (PICs): Essas células foram descritas como uma subpopulação que está presente no músculo, são miogênicas e 
podem dar origem à células satélites in vivo ${ }^{38}$. Curiosamente o potencial miogênico dessas células depende da expressão de Pax7, pois PICs de camundongos Pax $7^{-1-}$ não formam miotúbulos in vitro.

Muscle Derived Stem Cells (MDSC): MDSC são células que foram isoladas baseadas em suas características de fraca adesão à placa de cultura ${ }^{39}$. Ao contrário das PICs, essas células são miogênicas mesmo quando derivadas de camundongos $\mathrm{Pax}^{-{ }^{-}}$, e portanto se assemelham mais às Side Population Cells.

Fibro-Adipogenic Progenitors (FAPs): Essas células foram localizadas no interstício do músculo (da mesma forma que as PICs) porem essas não possuem nenhum potencial miogênico e somente têm capacidade de gerar tecido fibrótico e gordura. Todavia, essas células contribuem ativamente para a formação do ambiente necessário para a proliferação e diferenciação de mioblastos ${ }^{40}$.

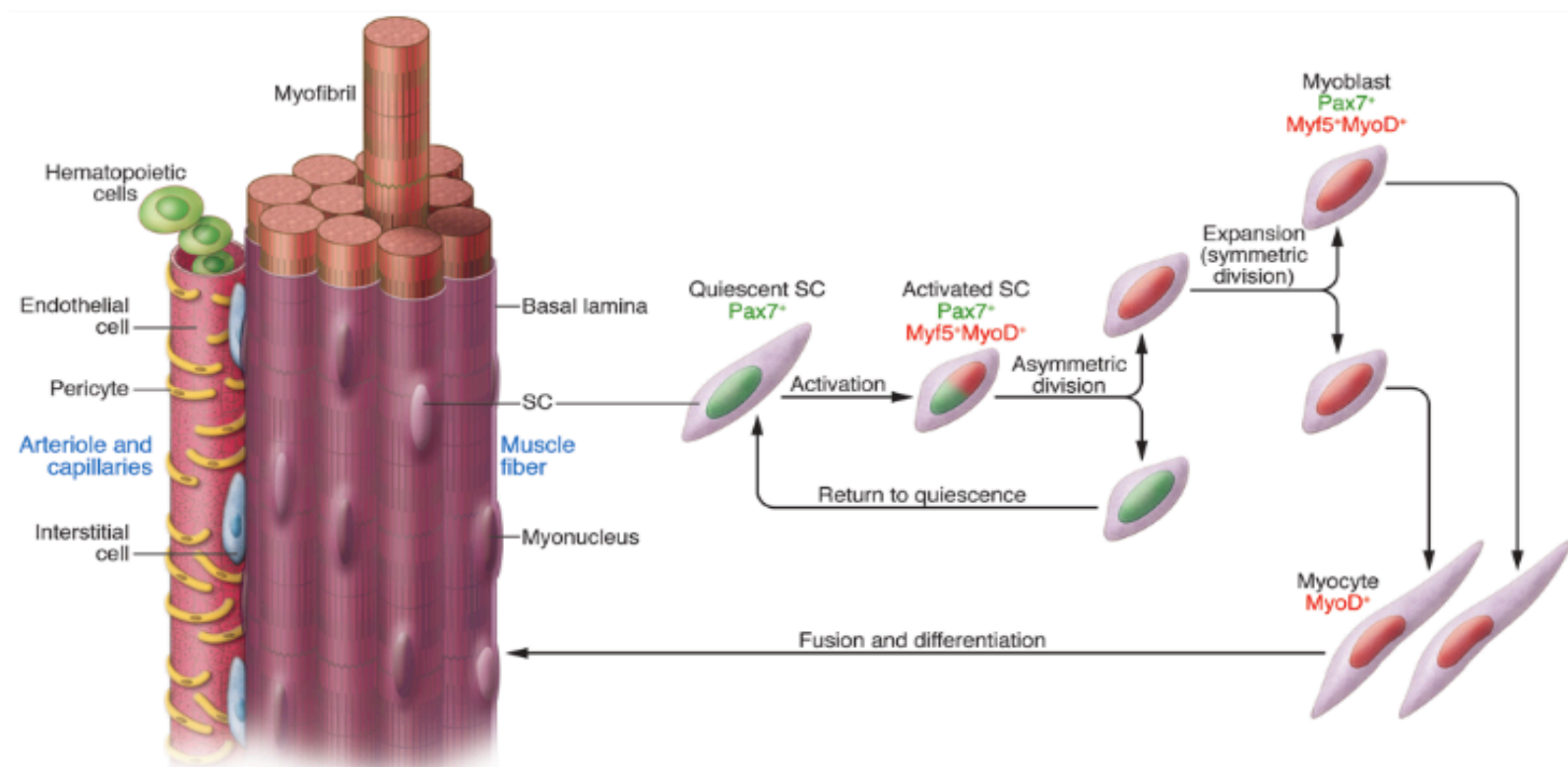

Figura 6: Esquema representativo de uma fibra muscular. Imagem retirada de Tedesco, 2010

Sendo assim, o que encontramos no músculo é um ambiente complexo no 
qual muitas células diferentes contribuem para a formação de um tecido saudável. 0 mecanismo de regeneração é um processo bem orquestrado para que o tecido seja restabelecido ${ }^{41}$. No caso das distrofias musculares progressivas, esse cenário precisa ser levado em consideração, pois sabe-se que existe um aumento de tecido fibrótico e gorduroso substituindo o muscular. Anteriormente à isso, acontece uma drástica diminuição do número de progenitores musculares ${ }^{33}$ e da sua capacidade proliferativa. Portanto, qualquer terapia para essas doenças precisa levar em consideração a atuação de todos estes componentes e não somente dos progenitores miogênicos.

\section{3 - Modelos Animais para DMPs}

Modelos animais são uma estratégia importante na compreensão de doenças que afetam seres humanos. Estes permitem o estudo mais detalhado das doenças gerando conhecimento sobre mecanismos que possibilitam o desenvolvimento de intervenções relevantes (drogas e terapias). Porém, não se deve desconsiderar as limitações destes, uma vez que apresentam diferenças significantes quanto a fisiologia e mecanismos moleculares. Os modelos podem variar desde invertebrados como o verme Caenorhabditis elegans e a mosca Drosophila melanogaster, peixes (zebrafish), mamíferos roedores (ratos, camundongos e coelhos), cães e até primatas (macacos).

Após a identificação do gene e da proteína responsável pela $\mathrm{DMD}^{42}$ foi possível a identificação e derivação de vários modelos para estudo como $\mathrm{C}$. elegans ${ }^{43}$, zebrafish ${ }^{44}$, gato ${ }^{45}$, camundongo ${ }^{46}$ e cachorro ${ }^{47}$. Cada um pode ser usado 
com um objetivo distinto, uma vez que cada modelo possui suas peculiaridades.

O uso de modelos como C. elegans estão mais voltados para manipulação gênica e entendimento do funcionamento de proteínas dentro de contexto de interação com outras proteínas, regiões mais relevantes de ativação e até reversão do fenótipo ${ }^{43}$. Já modelos de zebrafish são muito usados para screening de drogas ${ }^{48}$ pois o estudo pode ser escalonado de forma high-throughput devido ao seu tamanho pequeno, rápido desenvolvimento extra uterino, alta capacidade de reprodução e rápido desenvolvimento de uma geração (3 meses) ${ }^{44}$.

Quando se trata de modelos para distrofia muscular de Duchenne o modelo mais usado é o MDX, camundongo que tem uma mutação de ponto "sem sentido" no exon 23 que causa uma ausência de distrofina. No entanto, devido ao fato de naturalmente, durante o processo de splicing, o exon 23 ter a possibilidade de ser excisado, ainda são observadas as chamadas fibras revertentes em análises histológicas (fibras onde o processo de excisão aconteceu e portanto expressam uma versão funcional de distrofina) ${ }^{49}$. Desta forma, este modelo, apesar de natural, não representa com fidelidade a gravidade clínica encontrada em pacientes com DMD. Sabe-se que no MDX o processo de regeneração se sobrepõe ao da degeneração. Uma hipótese que foi proposta seria a grande diferença do tamanho dos telômeros entre humanos e camundongos, o que daria um limite realmente quase infinito de divisão à células satélites dos roedores. Quando o telômero é diminuído de forma experimental, esses animais acabam por demonstrar um fenótipo mais agressivo que o modelo clássico de $\mathrm{MDX}^{50}$.

A utrofina é uma proteína estruturalmente relacionada à distrofina. Elas compartilham diversas regiões importantes como um domínio N-terminal (ligação 
aos filamentos de actina), região repetitiva de bastão, domínio rico em cisteína e também a porção C-terminal que interage com proteínas transmembrana. Toda essa similaridade sugere uma redundância no nível de função. De fato, a utrofina é encontrada nas membranas sarcoplasmáticas musculares durante 0 desenvolvimento fetal e só após o nascimento é substituída por distrofina ficando unicamente restrita à regiões de placas motoras, conhecidas como junções neuromusculares (NMJ - do inglês Neuro-Muscular Junctions) ${ }^{51}$ e musculotendinosas (MTJ - do inglês Myotendinous Junctions) $)^{52}$. Camundongos knock-out para utrofina também mostram um fenótipo pouco expressivo clinicamente e com pequenas mudanças na arquitetura neuromuscular ${ }^{53}$. Sabe-se também que a expressão de utrofina é aumentada em camundongos $\mathrm{MDX}^{52}$ o que reforça a ideia de redundância na função dessas proteínas. Tendo isso em vista, foi feito um intercruzamento entre camundongos MDX e Utrofina negativos. Os animais duplo knockout (DKO) têm sinais clínicos importantes que os aproximam da doença observada em humanos tais como como perda de peso logo após ao desmame, contraturas, cifose e morte prematura aos 5 meses de idade ${ }^{54}$. Isso torna, estes animais um modelo valioso para a busca de terapias.

O modelo GRMD (do inglês Golden Retriever Muscular Dystrophy) é o melhor modelo por apresentar várias características comumente observadas em pacientes humanos. Os animais possuem uma mutação de ponto no intron 6 do gene da distrofina, que induz a excisão do exon 7 do RNAm final, alterando a fase do quadro de leitura e introduzindo um codon prematuro de parada no exon $8^{55}$. Níveis elevados de atividade da creatina quinase no soro, atrofia muscular forte com contraturas, necrose muscular, degeneração com mineralização, fibrose 
endomisial/perimisial e cardiomiopatia são algumas das semelhanças encontradas neste modelo em relação aos pacientes com DMD. Além disso, estes cães têm na idade adulta um peso comparável ao de uma criança (por volta de 15 quilos). Apesar de tantas semelhanças, algumas diferenças também existem como: alta taxa de mortalidade na fase perinatal e manutenção da capacidade ambulatória em animais adultos que sobrevivem ao primeiro ano de vida ${ }^{56}$. Entretanto, o custo de manutenção de uma quantidade de animais GRMD que poderia nos dar dados cientificamente relevantes é muito alto inviabilizando o estabelecimento de uma estrutura rotineira de experimentação.

Para este estudo foram escolhidos os animais duplo knockouts (DKO) MDX/Utrofina por suas manifestações clínicas e possibilidade de avaliar alteração na expectativa de vida desses animais.

\section{4 - Estratégias Terapêuticas}

Estratégias terapêuticas eficientes para DMPs têm sido objeto de inúmeras e complexas pesquisas. Isso porque as distrofias afetam um tecido que compõe $40 \%$ do indivíduo, com distribuição ubíqua e que é extremamente requisitado para diversas funções que vão de simples a voluntárias (como andar, manusear etc) a vitais (como respiração e batimentos cardíacos). Diversas terapias têm sido propostas para melhorar a condição de pacientes com distrofias musculares, particularmente a DMD, tais como: tentativas farmacológicas, terapia gênica e terapias celulares. No entanto, atualmente, a única forma de terapia aprovada para o tratamento de DMD permanece sendo os glicocorticoides, dos quais os mais 
usados são a prednisona e o deflazacorte.

\section{1 - Estratégias Farmacológicas}

Com relação ao uso de glicocorticoides, sua utilização inicial para distrofias musculares, em particular DMD, foi dada de forma totalmente empírica ${ }^{57}$. Os autores relataram a melhora de alguns sintomas de pacientes com DMD com uso de glicocorticoides como manutenção da capacidade ambulatória, aumento de velocidade, diminuição do número de quedas. Desde o primeiro estudo, muitos outros foram feitos ${ }^{58}$, inclusive um duplo cego randomizado que chegou à mesma conclusão de melhora clínica ${ }^{59}$. No entanto, essa terapia também causa efeitos colaterais indesejados como ganho de peso, osteoporose, diminuição de estatura, aumentos de pelos e sinais clássicos de Doença de Cushing. Acredita-se que o efeito benéfico observado na administração de glicocorticoides seja devido a sua ação imunomodulatória. Cada vez mais tem se observado a importância do papel do sistema imune em $\mathrm{DMPs}^{60}$. Estudos já mostraram que células musculares deficientes em distrofina são mais suscetíveis à necrose mediada por granulócitos do que células sem a mutação ${ }^{61}$. Uma outra hipótese aventada na década de 80 no nosso centro sugeria que a deficiência de hormônio de crescimento $(\mathrm{GH})$ poderia retardar a progressão do quadro clínico $^{62}$. Isso poderia também explicar parcialmente o efeito benéfico dos corticoides já que eles retardam o crescimento. Essa hipótese ganhou força novamente pela descrição recente de um paciente com DMD que consegue ainda andar aos 18 anos de idade. Ele foi tratado com corticoides desde os 2 anos de idade e apresenta um atraso importante de 
crescimento $^{63}$.

Ainda dentro de abordagens farmacológicas, existe uma tentativa terapêutica baseada na existência de codons de parada prematuros (PTC do inglês Premature Termination Codons) em mRNAs de genes reconhecidamente causadores de doenças genéticas como DMD e fibrose cística. No caso de DMD, cerca de $20 \%$ dos casos são mutações de ponto que culminam, após a transcrição do mRNA, com um PTC. Algumas drogas, com características bactericida, conhecidas como aminoglicosídeos, atuam em regiões ribossomais fazendo com que o ribossomo, por muitas vezes, não reconheça o códon de parada e permita que a proteína possa ser integralmente transcrita ${ }^{64}$. Porém, os graves efeitos colaterais do uso crônico de aminoglicosídeos induziram a comunidade científica a empreender em buscas por compostos alternativos com a mesma capacidade, porém sem seus efeitos colaterais. Recentemente, a droga PTC 124 foi tida como um promissor substituto da gentamicina em tratamento de doenças causadas por PTC ${ }^{65,66}$. No entanto, estudos posteriores mostraram que o efeito dessa droga pode ter sido erroneamente validado, indicando que, na verdade, ela não atua da mesma forma que a gentamicina e portanto mais estudos precisam ser realizados ${ }^{67}$.

Outra classe de terapias farmacológicas são os inibidores de deacetilases (HDACs do inglês Histone Deacetylases). Estudos mostravam que compostos químicos não relacionados estruturalmente, porém com descrita função de inibir deacetilases, aumentavam a diferenciação miogênica ${ }^{68}$. Com essa perspectiva, estudos funcionais e morfológicos foram feitos em camundongos MDX e indicaram uma melhora substancial ${ }^{69}$. De fato, em 2011 existiam cerca de 100 tentativas terapêuticas com inibidores de $\mathrm{HDACs}^{70}$. Apesar do grande esforço para se traduzir 
a pesquisa em terapia, algumas perguntas permanecem sem respostas também na abordagem farmacológica. As vias que são verdadeiramente comprometidas ou ativadas com a inibição dessas enzimas precisam ser mais bem compreendidas, bem como os melhores inibidores e suas concentrações terapêuticas.

\section{2 - Terapia Gênica}

Terapia gênica é uma alternativa muito interessante mas que enfrenta grandes desafios $^{71}$. No caso de DMPs, precisa atingir todos os músculos do paciente e é necessário determinar a melhor forma de "entregar" o gene avaliando as vantagens e desvantagens de se corrigir a falha no gene ou substituí-lo por completo. Essa terapia requer também que se aprenda a driblar os problemas imunes não só inerentes a técnica mas também referente a expressão da proteína alvo que pode ser reconhecida como "estranha" pelo paciente ${ }^{72}$. Especula-se (por experimentos em modelos animais) que o nível necessário de aumento para trazer qualquer benefício clínico para um paciente seja de $20 \%{ }^{73}$. Muitas abordagens de terapia gênica têm sido propostas como: entrega de variadas formas de minidistrofinas $^{74}$, oligonucleotídeos anti-sense (AO do inglês anti-sense oligonucleotides) ${ }^{75}$, vetores associados para indução de exon skipping ${ }^{76}$, dentre outras. Esta última estratégia merece detalhamento por apresentar resultados preliminares animadores.

A abordagem se baseia no mesmo princípio de correção de quadro de leitura ou retirada de PTC através do mecanismo de exon skipping. Uma das grandes dificuldades desse processo consiste na variabilidade de absorção dos AOs nos 
tecidos alvo após várias aplicações sistêmicas ${ }^{77}$, inclusive no tecido cardíaco $^{78}$. $\mathrm{Na}$ estratégia proposta por Goyenvalle e colaboradores ${ }^{76}$ os AOs são conjugados com snRNAs (do inglês small nuclear RNAs) para facilitar a sublocalização nuclear necessária para o processamento dos RNAs alvo e também proporcionar uma maior estabilidade. Em um estudo recente ${ }^{79}$ uma única administração de vetores virais, contendo os AOs conjugados, em camundongos duplo Knock-outs (DKO) de MDXutrofina foi suficiente para gerar expressão contínua de distrofina modificada e corrigida por até 1 ano. Os camundongos tratados apresentam melhoras clínicas significantes, com curvas de sobrevivência muito acima do esperado. Esta terapia, portanto, se mostra bastante promissora para melhoria das condições de tratamento de pacientes com DMD.

\section{3 - Terapia Celular}

A terapia celular é uma proposta que tem ganhado força nos últimos anos. Atualmente, para as DMPs existem, basicamente, duas abordagens: a primeira é a perspectiva da medicina regenerativa, cuja a proposta é a recuperação tecidual através do transplante de células saudáveis que substituem e compensam as células deficientes do paciente culminando numa melhora clínica perceptível (como no caso de transplante de células-tronco hematopoiéticas em pacientes com leucemia); já a segunda se baseia na modulação imunológica através de um efeito parácrino das células transplantadas no tecido alvo (músculo) ou até mesmo diretamente no sistema imune do paciente. Ambas abordagens serão discutidas nesta tese. 


\subsection{1 - Terapia Celular - Regeneração}

Com relação a regeneração tecidual, as células poderiam ser obtidas do paciente, corrigidas ex-vivo e depois transplantadas no mesmo paciente (transplante autólogo); ou derivadas de um doador não afetado e transplantado para o paciente $^{71}$. Do ponto de vista prático, as células ideais para uma terapia celular de regeneração para DMPs deveriam preencher os seguintes critérios ${ }^{80}$ :

- estarem presentes em tecidos acessíveis e pós gestacionais;

- serem capazes de expansão in vitro para suprir uma necessidade terapêutica;

- serem capazes de ser modificadas geneticamente com vetores virais;

- atingir o tecido muscular por via sistêmica ultrapassando a barreira endotelial (do contrário, seria muito difícil tratar todos os músculos do corpo).

Inicialmente, a abordagem mais direta foi verificar se o transplante de CSs (ou os seus representantes proliferativos in vitro conhecidos como mioblastos) poderia ser usado como uma possibilidade terapêutica. Apesar de não ter sido um consenso na comunidade científica da época ${ }^{81}$, os testes clínicos começaram e indicaram uma recuperação não satisfatória dos pacientes transplantados. As causas do insucesso dos testes foram descritas como sendo relacionadas às baixas taxas de integração e proliferação dos mioblastos, resposta imune e impossibilidade de entrega (delivery) das células aos maiores músculos do corpo ${ }^{81}$.

Posteriormente, iniciou-se uma busca por um tipo celular que pudesse preencher os critérios necessários para uma terapia. Desde então, diversos tipos 
celulares já foram descritos com potencial de formar músculo in vivo em modelos pré-clínicos como: células da medula óssea ${ }^{82,37,83}$, side population cells ${ }^{84,85}$, muscle derived stem cells ${ }^{39}$, mesoangioblastos ${ }^{86,87,88,89}$ e células do pericito ${ }^{80,90}$. As células-tronco mesenquimais começaram a aparecer de forma muito evidente na literatura científica como possibilidade terapêutica das mais diversas doenças. Sendo assim, nos aprofundaremos nos aspectos mais histórico-científicos desse tema.

\section{Células-Tronco Mesenquimais}

O conceito atual encontrado na literatura com relação às chamadas CélulasTronco Mesenquimais (CTMs) é bastante confuso como descrito a seguir.

O conceito teórico de células-tronco pode ser rastreado desde o final do século 19 e envolvia a ideia de tecidos poderem ser renovados durante toda a vida de um indivíduo mesmo sendo constituído por células que vivem pouco ${ }^{91}$. Muito tempo depois, o entendimento de células-tronco como entidades discretas veio acompanhado de ensaios biológicos precisos, que corroboram os conceitos propostos de auto renovação e diferenciação.

O primeiro trabalho que descreveu uma população de células com potencial "esqueletogênico" surgiu em 1968, quando Travassoli e colaboradores transplantaram porções de medula óssea desossada em diferentes tecidos de ratos para verificar se a medula óssea poderia ser formada em outros tecidos que não dentro dos $\operatorname{ossos}^{92}$. O resultado (formação completa da medula em todos os tecidos) demonstrava que no material transplantado havia todos os componentes 
necessários para formação da medula e de um nicho necessário para hematopoese. Friedenstein e colaboradores ${ }^{93}$ mostraram que a formação dessas estruturas ósseas/medulares em transplantes heterotópicos - isto é, um transplante de um tecido em um lugar onde normalmente ele não é desenvolvido - estava relacionado a um grupo de células que não crescia em suspensão, mas sim aderidas à placa de cultura. Posteriormente, o mesmo grupo conseguiu definir que essa população de células do estroma da medula era responsável pela formação de várias estruturas esqueléticas e estromais (gordura, osso, cartilagem e fibroblastos) in vivo e todas essas estruturas eram derivadas de linhagem de origem clonal que foram definidas como CFU-F (do inglês Colony Forming Unit - Fibroblast) ${ }^{94}$. Surgia assim o conceito de células-tronco esqueléticas ou estromais (do inglês Skeletal Stem Cells ou Stromal Stem Cells). Essas células comprovadamente eram multipotentes e tinham potencial de proliferação, já que podiam formar tecidos in vivo. A compreensão melhor de como as células-tronco hematopoiéticas interagiam com o estroma da medula foi surgindo com a noção de que havia na verdade dois tipos de células-tronco no microambiente da medula óssea: a que dava origem ao sangue e seus componentes (hematopoiética) e aquela que dava origem ao tecido esquelético de suporte, ou estromal, para desenvolvimento da hematopoese (célula-tronco esquelética ou estromal de medula óssea).

No entanto, apesar de todo o fundamento teórico-científico corroborado através de experimentos bem estabelecidos de transplantes heterotópicos, as CTMs não ganharam muita atenção até o final da década de $90 \mathrm{com}$ um trabalho que descreveu o isolamento, caracterização, forma de cultivo e proliferação in vitro de CTMs de medula óssea humana ${ }^{95}$, supostamente o mesmo tipo de células com as 
quais os grupos de Friedenstein e Travassoli trabalharam em modelos animais. Curiosamente, o termo usado nessa publicação para descrever tais células foi o de Mesenchymal Stem Cells (Células-tronco Mesenquimais - CTMs), termo proposto em 1991 por Arnold Caplan ${ }^{96}$ para descrever um tipo de célula precursora presente no desenvolvimento embrionário que dá origem a diversos tipos de tecidos ${ }^{97}$. Esse termo foi amplamente adotado pela literatura científica ${ }^{98}$ (em detrimento dos termos anteriormente propostos como célula-tronco esquelética ou estromal de medula óssea), apesar do próprio trabalho de Pittenger não ter avaliado in vivo se a forma de cultivo descrita para as CTMs de medula óssea humana era suficiente para manter a capacidade de formação de medula, osso e condrócito em transplantes heterotópicos. É digno de nota que em um trabalho publicado pelo grupo de Arnold Caplan em $1992^{99}$ a forma de cultivo das células (expansão ex-vivo) foi tida como uma provável explicação da perda de capacidade condrogênica dessas células (pois não foi observada condrogênese in vivo). Nesse cenário, o termo Célula-Tronco Mesenquimal (CTM) passou a assumir um conceito de um tipo celular pós-natal ainda não evidenciado cientificamente - derivado de uma célula mesenquimal embrionária $^{96}$ (Figura 7), com a função de manter a renovação de tecidos de origem mesenquimal durante a vida do indivíduo. Assim como as Células-Tronco Hematopoiéticas (CTHs), as CTMs hipoteticamente estariam no topo da hierarquia dos tecidos de origem mesenquimal e progrediriam por diversas etapas de diferenciação para gerar/repor tecidos maduros como osso, cartilagem, tendões, músculo etc ${ }^{100}$. Essa atrativa hipótese acabou por trazer a possiblidade de diversos estudos nos quais as células descritas por Friedenstein se tornaram o principal exemplo, mesmo não cumprindo todos os requisitos necessários (como por exemplo 
capacidade de diferenciação em músculo, um tecido derivado da mesoderme).

Diante da euforia das perspectivas, noções muito importantes e válidas aprendidas em experimentos in vitro e in vivo mais tradicionais foram sendo desconsideradas. Por exemplo, a observação de unidades formadoras de colônia, CFUs, passou a ser entendida como propriedade de auto renovação e testes de diferenciação in vitro com combinações de fatores passaram a ser considerados como representação de potencial in vivo. Logo, uma quantidade cada vez maior de estudos concluíam que células de diferentes sítios ${ }^{101}$ e tecidos tinham o mesmo

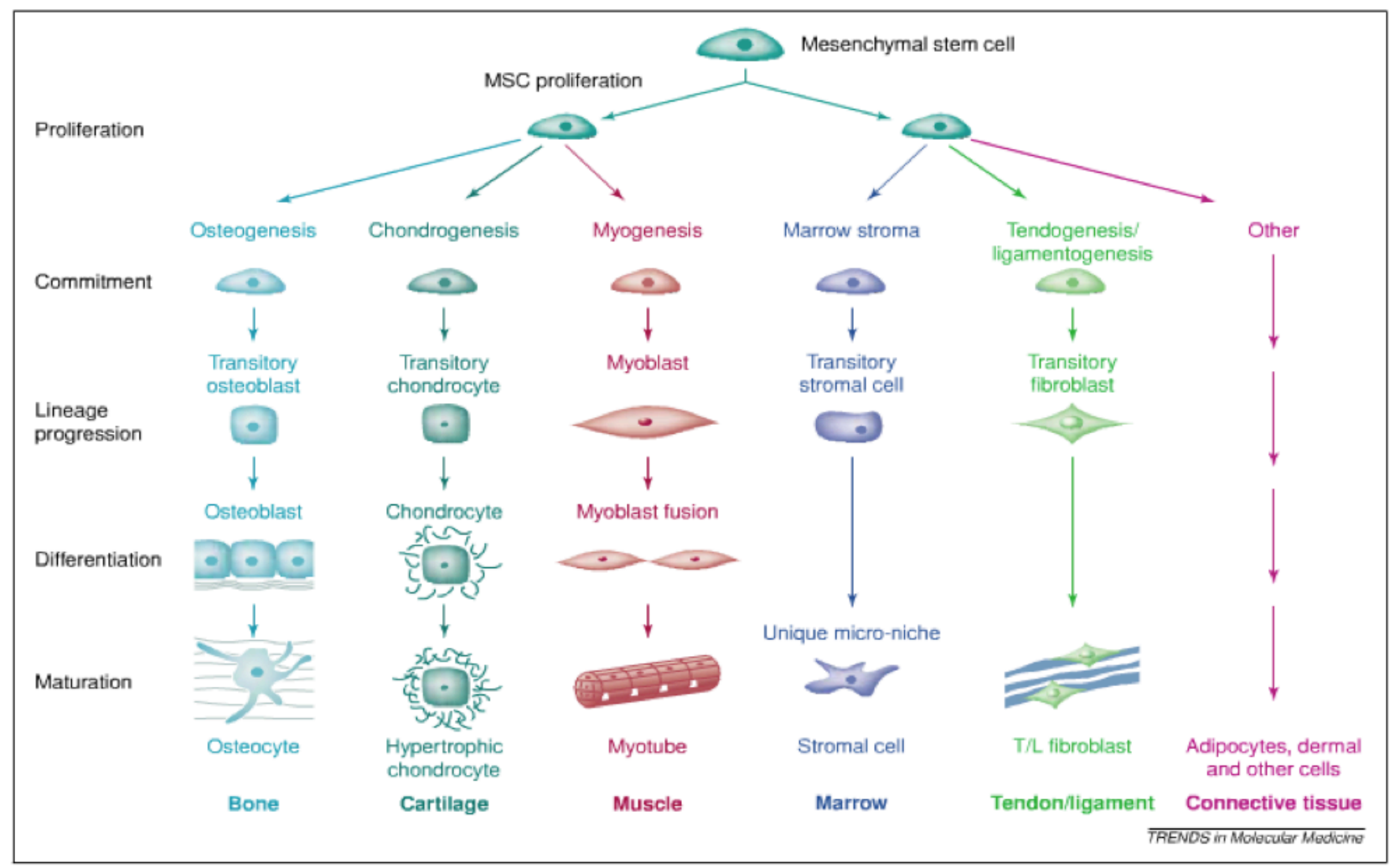

Figura 7: Esquema proposto por Caplan ${ }^{93}$ para o potencial das CTMs. Imagem retirada da publicação.

potencial "tronco" proposto inicialmente por experimentos realizados unicamente com células derivadas de medula óssea. Estudos atuais indicam que esses protocolos in vitro, como o teste de diferenciação tecidual, se correlacionam muito pouco com a realidade biológica observada ${ }^{102}$. As controvérsias dos experimentos atuais existem exatamente porque os diferentes métodos aplicados e a ineficácia 
dos experimentos in vitro (tidos como válidos) obscurecem os fatos que determinam o real potencial das células. Apesar de haver evidências ${ }^{103,104}$ sobre a plasticidade exacerbada de CTMs (somente de medula óssea), os dados ainda são incipientes para afirmações categóricas e precisam ser embasados em condutas experimentais bem estabelecidas que verdadeiramente comprovem tais afirmações. Hoje, nota-se na literatura científica que o conceito de CTMs não obedece aos rígidos testes experimentais, gerando uma multidão de dados, não reproduzíveis e com as mais diversas extrapolações. Por exemplo, a capacidade de diferenciação que ultrapassaria a barreira estabelecida embrionariamente pela diferenciação dos folhetos - tecidos da mesoderme dando origem a tecidos da ectoderme.

Para avaliação de potencial miogênico encontramos problemas ainda maiores. Sabe-se que até mesmo células linfoides podem ser reprogramadas através de fusão com progenitores musculares ${ }^{105} \mathrm{e}$, portanto, a avaliação deste potencial fica comprometida com experimentos de co-cultivo com mioblastos. Indução miogênica a partir de agentes demetilantes como a 5-azacitidina também não verificam com fidelidade o potencial da célula, apesar de ser muito utilizado ${ }^{106}$. Acredita-se que a exposição de 5-azacitidina induza uma transcrição generalizada no genoma e que o programa miogênico seja dominante diante de outras vias de diferenciação ${ }^{107}$. Como mencionado anteriormente, as células satélites permanecem como o único tipo celular com potencial comprovadamente auto renovador e miogênico ${ }^{20,24}$. Não podemos deixar de citar que também foram encontrados indícios fortes de que havia progenitores musculares na medula óssea durante a busca por células que pudessem servir de terapia para $\mathrm{DMPs}^{82,37}$. Porém estudos posteriores indicaram que o potencial terapêutico alcançado era insuficiente para 
gerar alguma melhora clínica quando avaliada em camundongos ${ }^{108}$.

Em 2007, Dellavalle et $a^{80}$ descreveu uma população de células que aderia fracamente a placa de cultivo, mas que tinha grande potencial proliferativo e era capaz de diferenciar-se in vitro e in vivo em células musculares depois de transplante sistêmico através da artéria femoral (cerca de 10\% das células foram encontradas nos músculos imediatamente irrigados pela artéria enquanto nos músculos contralaterais, menos de 1\%). Através de FACS (do inglês Fluorescent Activated Cell Sorting) e usando o marcador ALP (do inglês Alcaline Phosphatase) essas células foram isoladas diretamente do tecido e expressavam vários outros marcadores claros de células de pericito, se distinguindo em diversos aspectos de CSs (especialmente na forma de cultivo). Essas células foram, portanto, caracterizadas como uma população diferente das CSs e chamadas de células do pericito. Posteriormente o mesmo grupo conseguiu provar, através de manipulação de animais transgênicos, que pericitos participam naturalmente do processo de regeneração celular e até da formação de células satélites ${ }^{109}$.

Concomitantemente, Sacchetti e colaboradores descreveram os marcadores que identificavam a população de células humanas responsável pela formação de medula em transplantes heterotópicos ${ }^{110}$. Essas células expressavam altas quantidades do marcador CD146. In situ, esse marcador somente estava associado à células reticulares adventícias que também expressam CD105 e fosfatase alcalina (ALP) mas não apresentavam marcadores endoteliais. Experimentos de expressão mostram que essas células apresentam características de células de pericito. Sabia-se que a quantidade de células progenitoras estromais na medula correlaciona-se com a vascularização deste órgão, que decai com a 
idade, e, mais uma vez, apontando para uma célula relacionada à vascularização (Figura 8).

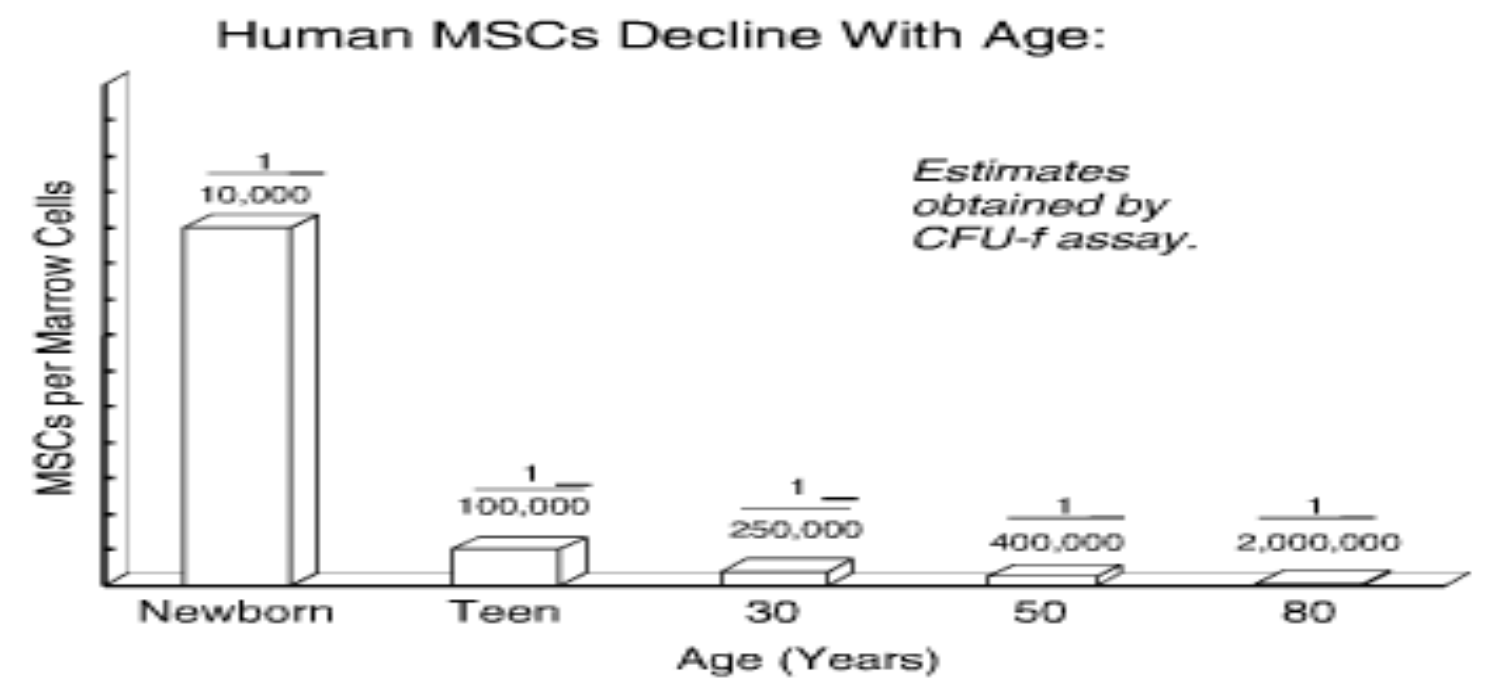

Figura 8 - Relação da quantidade de CTMs encontrada na medula com a idade. Imagem retirada de Caplan, $2009^{1}$

Já em 2008, Crisan e colaboradores ${ }^{90}$ mostraram que essas células CD146+ (pericito) estavam presentes em diversos tecidos do corpo como cérebro, pâncreas, gordura e músculo. Através de marcadores bem definidos, foi possível isolar essas células de todos os tecidos citados e o potencial miogênico foi avaliado diretamente após a separação por FACS (através de injeção em músculo de camundongos lesionados com cardiotoxina - in vivo). Sendo assim, podemos observar que apesar de muitas variedades em protocolos, formas de cultivo e derivação de células, existe uma convergência de resultados que apontam para um caminho mais sólido na compreensão deste assunto tão vasto.

Portanto, a manutenção dos critérios experimentais rígidos que permitem identificar, em meio a tanta variabilidade, a real população de células que podem contribuir com a regeneração tecidual é de grande importância. Atualmente, o pericito seria o único tipo celular bem descrito, presente em todos os tecidos (in vivo) com protocolos avançados de estudo e marcadores que permitem 
experimentos de comparação quanto ao potencial de diferenciação ${ }^{111}$.

\subsection{2 - Terapia Celular - Modulação (efeito parácrino)}

Diante da euforia sobre o proposto potencial regenerativo das CTMs, rapidamente ficou evidente que na maioria dos modelos usados, os efeitos benéficos observados não se correlacionavam com a quantidade de células encontradas ou, até mesmo diferenciadas, nos tecidos alvo. Em ensaios para infarto do miocárdio, derrame e regeneração do menisco, inicialmente propostos como terapia regenerativa, a melhora observada foi sugerida como resultado de efeitos tróficos das células transplantadas (revisado por Caplan ${ }^{112}$ ). Também já se sabia a respeito da miríade de fatores liberados por essas células em condições de cultivo ex vivo (Figura 9).

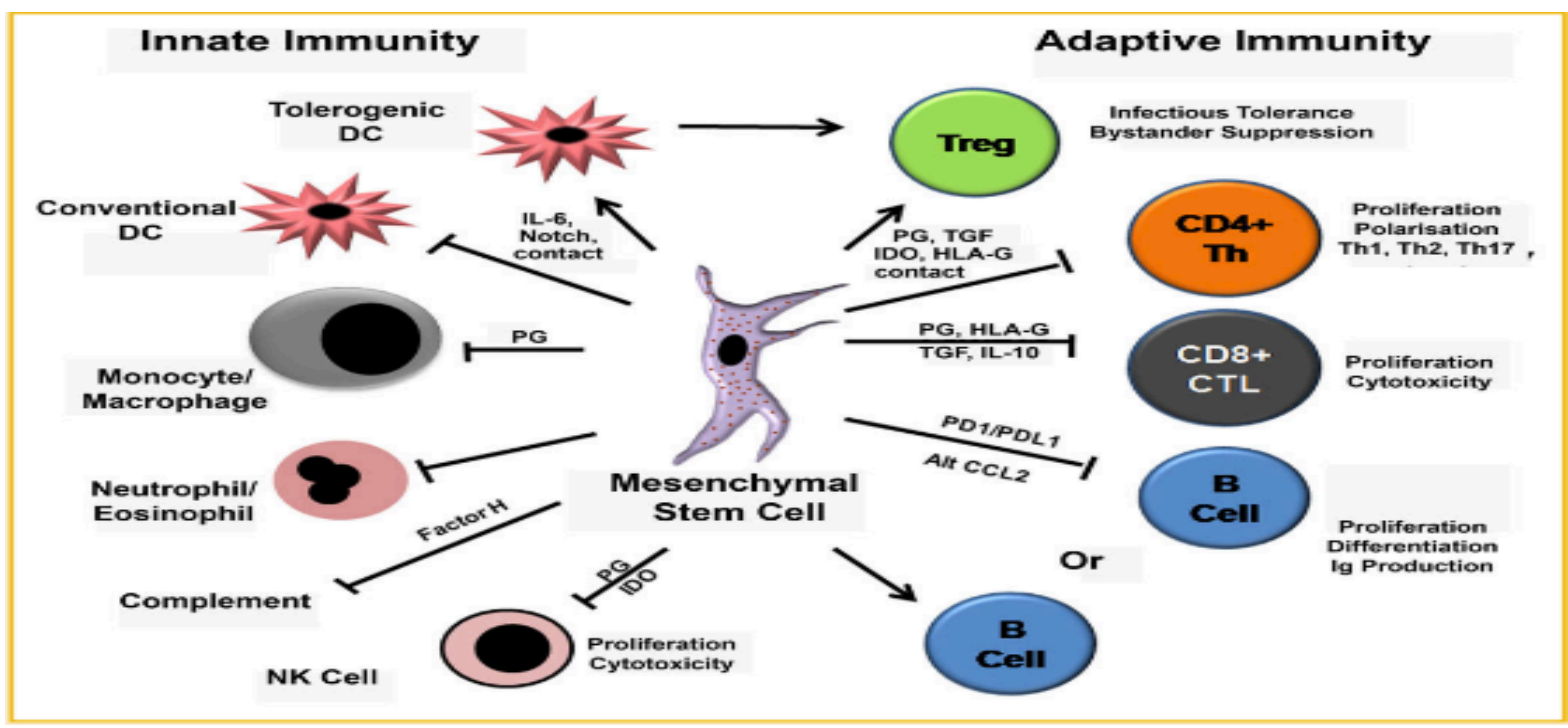

Figura 9: Exemplo de citocinas liberadas pelas CTMs. Imagem retirada de English, $2011^{2}$

Tendo isso em mente, uma série de experimentos foram conduzidos para verificar o potencial modulatório dessas células. Esses experimentos comprovam 
que CTMs derivadas de medula realmente possuem um potencial de inibir a proliferação de linfócitos $\mathrm{T}^{113}$ (quando alogenicamente estimulados ou até mesmo diante de estímulos de moléculas mitógenas como a ConA ${ }^{114}$ ). Neste último estudo, foram avaliados a tolerância de transplantes de pele alogênicos em babuínos, o mesmo teste realizado para se comparar o potencial imunomodulatório de drogas imunossupressoras como fludaribine e ciclosporina A com anit-CD80. Nestes testes observou-se uma tolerância de 11-12 dias, após uma única infusão de CTMs de medula no dia 0. Drogas imunossupressoras causaram tolerância de 14 dias. Esses resultados, apesar de preliminares devido ao seu pequeno número amostral, estão associados a outros trabalhos em humanos ${ }^{115,116}$ e indicam um potencial relevante de efeitos imunomodulatórios. Desde então, diversos estudos foram feitos buscando entender os mecanismos mais importantes envolvidos nesse processo e os limites de cada um deles .

Em revisões recentes ${ }^{117}$, as propriedades imunomodulatórias foram unicamente observadas, com fortes indicações experimentais, em CTMs derivadas de medula óssea (experimentos com modelos babuínos e até humanos). No entanto, isso não garante a mesma propriedade para células derivadas de outros tecidos $^{101}$. Portanto, torna-se necessário evocar novamente os critérios rígidos experimentais que permitem conclusões válidas sobre resultados robustos para cada tipo celular antes de se concluir a respeito de futuras terapias utilizando-se de fontes alternativas que, apesar de mais abundantes, ainda não foram rigidamente verificadas com potencial imunomodulatório.

Recentemente, pericitos descritos como originários de mesoangioblastos, também foram avaliados in vitro quanto à sua função imunomodulatória ${ }^{118}$. Os 
resultados indicam que essas células modulam a proliferação de linfócitos e o efeito é dependente de dose e do tempo ${ }^{119}$. É válido lembrar que, apesar de muitos considerarem que a população heterogênea de CTM contém células de pericitos, estudos mais profundos argumentam que são na verdade duas populações diferentes e portanto com características individuais distintas ${ }^{120}$.

Levando em consideração todas as premissas dispostas nessa introdução, esse projeto visa comparar o potencial miogênico de diferentes tipos de CTMs derivadas em nosso laboratório para saber qual seria o melhor tipo a ser usado numa possível terapia celular para pacientes de DMPs. 


\section{II-Objetivos}

1. Comparar diferentes tipos de células-tronco mesenquimais (CTMs) quanto ao potencial miogênico in vitro;

2. Separar e caracterizar populações de células de pericito de diferentes tecidos;

3. Comparar o potencial miogênico de células de pericito da mesma pessoa;

4. Testar o efeito in vivo de células de pericito em modelo de camundongo DKO MDX/Utrofina. 


\section{Capítulo 2}

\section{I - Isolamento de células-tronco mesenquimais de tecidos diferentes através de métodos clássicos}

O objetivo inicial do presente estudo era comparar o potencial miogênico de 3 dos muito tipos diferentes de CTMs. Por critérios de facilidade de obtenção e abundância optamos por células-tronco derivadas de cordão umbilical (UCMSC - do inglês Umbilical Cord Mesenchymal Stem Cells) ${ }^{121}$ e de sangue de menstruação (ERCs - do inglês Endometrial Regenerative Cells) ${ }^{122}$. Como controle positivo usamos uma célula denominada FMDSC (do inglês - Facial Muscle Derived Stem Cells) ${ }^{123}$. Todas essas são células obtidas de material descartado e derivadas de tecidos pós-natal e portanto são consideradas células-tronco adultas (CTAs).

As células tronco de cordão umbilical são isoladas através de um processo simples, seguro e não doloroso, não causando nenhum dano para a saúde da mãe ou do recém nascido. A grande vantagem de se estudar um tratamento a partir deste tipo celular é o fato de serem encontradas em um tecido normalmente descartado após o nascimento, mas que podem prover fontes valiosas para a pesquisa devido a sua fração hematopoiética (presente no sangue do cordão) e mesenquimal (presente no tecido do cordão).

Em 2007, foi descrito o isolamento de células-tronco mesenquimais do sangue de menstruação. Os autores relatam que o processo angiogênico é critico 
para o crescimento endometrial no ciclo menstrual sendo, portanto, aceitável assumir a existência de uma população de células-tronco nesse ambiente. Os autores descrevem a diferenciação dessas células, chamadas de Endometrial Regenerative Cells (EGC), em tecidos dos três folhetos embrionários (endoderme, mesoderme e ectoderme). Este fato torna as ERCs uma alternativa interessante a ser investigada dada a facilidade de coleta (método não invasivo) e o aparente grande potencial $^{122}$.

Outra fonte de CTA de interesse para o estudo da miogênese são as células tronco dos músculos esqueléticos. Estes podem ser divididas em dois tipos principais: os músculos esqueléticos craniofacial (MECF) e dos músculos esqueléticos (ME). Existem algumas propriedades que podem separar esses tipos musculares como a origem embriológica ${ }^{124}$ e a expressão distinta de fatores miogênicos e seus receptores em relação aos músculos esqueléticos em geral ${ }^{125}$. Por exemplo, o clássico fator de transcrição Pax3 é um marcador para músculo esquelético, mas não para os músculos faciais ${ }^{126}$. 0 mesmo acontece com o gene Lbx1 que é expresso nos músculos dos membros e somíticos e não nos músculos da face ${ }^{127}$. Estudos recentes analisaram o número de células satélites (CS) por milímetro de miofibrila comparativamente entre ME e MECF. Estes pesquisadores observaram que no primeiro havia 26 CSs enquanto no último foram encontradas 70, demonstrando que os músculos da face podem ser mais ricos em células progenitoras musculares.

Portanto, linhagens obtidas desses 3 tipos de CTMs permitem uma comparação acerca de seu potencial miogênico. 


\section{II - Métodos para caracterização in Vitro}

As formas de isolamento e cultivo dessas células são descritas mais detalhadamente a seguir:

UCMSC - Os cordões umbilicais foram obtidos após o consentimento livre e esclarecido das mães conforme o protocolo apresentado ao comitê de ética. 0 isolamento das células e o cultivo foram feitos conforme o protocolo descrito anteriormente $^{128}$. Brevemente, um pedaço do cordão umbilical de crianças nascidas a termo, de aproximadamente $10 \mathrm{~cm}^{2}$, é extensivamente lavado com PBS e restos de sangue coagulados são retirados do interior dos vasos. Depois, uma solução de colagenase tipo 1A (Sigma) de 1\% diluída em PBS é colocada dentro dos veias e incubada em banho maria a $37^{\circ} \mathrm{C}$ por 20 minutos. Logo após, todo o tecido do cordão é lavado com meio de cultivo (DMEM low glicose com $10 \%$ de soro fetal bovino) e comprimido, retirando assim a estrutura gelatinosa conhecida como Wharton's Jelly resultante da digestão (figura 10). Essa estrutura gelatinosa é

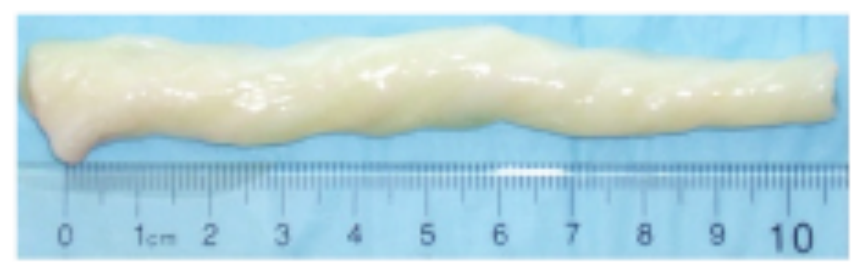

(a)
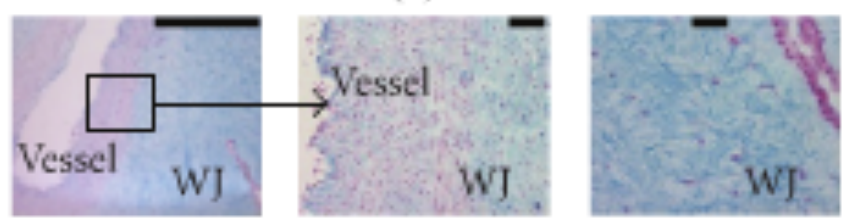

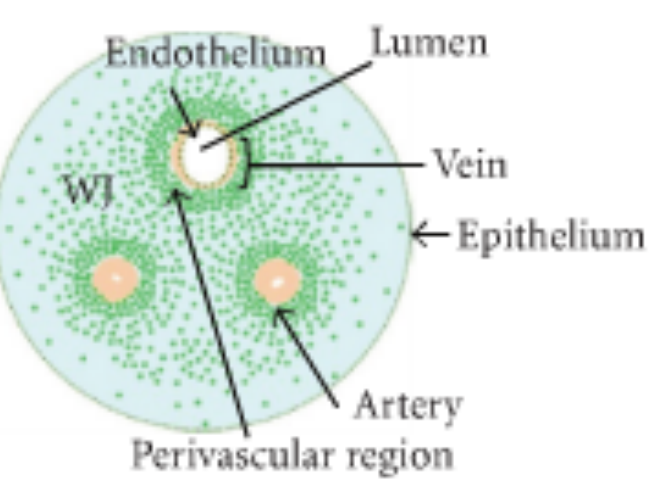

Perivascular region

Figura 10 - Esquema e figuras relacionadas ao cordão umbilical . Retirada de Schugar, $2009^{4}$

centrifugada a $400 \mathrm{~g}$ por 10 minutos e resuspendida em até $10 \mathrm{~mL}$ de meio de cultivo e plaqueada em garrafas de $25 \mathrm{~cm}^{2}$. Após 24 horas, o meio de cultivo é trocado e as 
células não aderentes são descartadas. Nesse período pequenas colônias de células já estão aderidas.

FMDSC: As biópsias do músculo orbicular do lábio foram retiradas de controles normais, após seu consentimento, e foram isoladas de acordo com o protocolo estabelecido pelo nosso grupo: o tecido conjuntivo ao redor da biópsia é cuidadosamente retirado e as amostras do músculo orbicular do lábio são extensamente lavadas com PBS estéril $(0,01 \mathrm{M}, \mathrm{pH}=7,4)$, suplementado com $4 \%$ de antibióticos (100 unidades $/ \mathrm{ml}$ de penicilina e $100 \mu \mathrm{g} / \mathrm{ml}$ de estreptomicina, Invitrogen), para remover detritos contaminantes e células sanguíneas; em seguida é digerido com solução de tripsina (TrypLe, Invitrogen) por 1 hora á $37^{\circ} \mathrm{C}$. Uma vez digerido, o tecido é transferido para uma placa de petri de $35 \mathrm{~mm}$ (Corning, NY) contendo meio de cultura DMEM/ F12 (Dulbecco's modified Egle's Médium/ Hans F12; Invitrogen) suplementado com $15 \%$ de soro fetal bovino (FBS, Hyclone, Washington), $2 \mathrm{mM}$ de I-glutamine, $2 \mathrm{mM}$ de aminoácidos não essenciais (Invitrogen), 100 unidades $/ \mathrm{mL}$ de penicilina e $100 \mu \mathrm{g} / \mathrm{mL}$ de estreptomicina (Invitrogen). A cultura crescente dessas células é mantida sob tais condições por duas semanas e depois as células são lavadas duas vezes com PBS, dissociadas com uma solução de tripsina e replaqueadas para expansão.

ERC - As células provenientes de sangue de menstruação foram obtidas de coletas de mulheres saudáveis após consentimento. O sangue menstrual é coletado com tubo estéril e colocado em PBS com 1\% de antibiótico e antimicótico. As células mononucleadas são separadas por gradiente de Ficoll-Paque durante $30 \mathrm{~min}$ de centrifugação sem freio. As células são então plaqueadas em meio DMEM F12 com $15 \%$ de soro fetal bovino. 
Todas as populações descritas até aqui são heterogêneas por natureza e isoladas por suas propriedades de aderência à placa.

A caracterização das linhagens foi realizada pela análise de marcadores de superfície celular por citometria de fluxo e pelo potencial de diferenciação (miogênica, adipogênica e osteogênica).

Os marcadores mais utilizados em citometria de fluxo e que são mais aceitos como presentes nas linhagens de CTMs são: CD13, CD29, CD44, CD105(SH2), CD106, CD73(SH3), HLA-ABC, CD14, CD34, CD38, CD45, CD31 e HLA-DR.

O potencial de diferenciação das diferentes linhagens de UCMSC, ERC e FMDSC foi investigado através da indução à diferenciação por meios de cultivo determinados e protocolos previamente descritos ${ }^{121}$.

Com relação a diferenciação miogênica, além de avaliar a morfologia geral das células e o tempo necessário para a completa mudança para miotúbulos, foi analisada também a expressão de proteínas musculares por PCR tempo real, Western Blotting e imunofluorescência. Foram coletados RNAs das células cultivadas em diferentes tempos após o inicio da indução à diferenciação miogênica. Foram analisados marcadores já comprovadamente ligados a diferenciação em músculo tais como Myf5, Mrf4, Miogenina, MyoD, cadeia pesada da miosina e distrofina. Comparou-se até 3 tipos de meios de diferenciação miogênica.

\section{III - Resultados}

Durante a primeira etapa do trabalho focamos no isolamento e caracterização dos três tipos celulares com os quais nos propusemos a trabalhar: UCMSC (Umbilical Cord Mesenchymal Stem Cells), ERG (Endometrial Regenerative 
Cells) e FMDSC (Facial Muscle Derived Stem Cells). Foram derivadas diversas linhagens (mais de 30 para UCMSC e ERG; mais de 15 para FMDSC) de cada uma das células-tronco mesenquimais (CTMs). Após a obtenção das células, estas foram cultivadas até a passagem 5 (quantidade estimada para que, partindo de 2 garrafas iniciais de $25 \mathrm{~cm}^{2}$, obtivéssemos um número suficiente de células para realizar todos os experimentos com cada linhagem). Obteve-se 3 linhagens estocadas de cada fonte que apresentaram um resultado similar quanto aos seus marcadores de citometria, e que portanto poderiam ser usadas nos experimentos posteriores (tabela 1).

Tabela 1: Frequência dos marcadores nas linhagens derivadas de CTMs

\begin{tabular}{|c|c|c|c|c|}
\hline \multirow[t]{2}{*}{ Marcadores } & \multicolumn{4}{|c|}{ Linhagens de UCMSCs } \\
\hline & UCMSC 1N & UCMSC 3N & UCMSC 5N & Media \\
\hline CD 13 & $99,50 \%$ & $99,40 \%$ & $97,40 \%$ & $98,77 \%$ \\
\hline CD 29 & $99,00 \%$ & $98,90 \%$ & $99,80 \%$ & $99,23 \%$ \\
\hline CD 31 & $0,34 \%$ & $1,16 \%$ & $1,60 \%$ & $1,03 \%$ \\
\hline CD 34 & $0,74 \%$ & $2,90 \%$ & $2,50 \%$ & $2,05 \%$ \\
\hline CD 44 & $99,00 \%$ & $99,40 \%$ & $99,60 \%$ & $99,33 \%$ \\
\hline CD 45 & $0,58 \%$ & $0,70 \%$ & $1,78 \%$ & $1,02 \%$ \\
\hline CD 73 & $85,70 \%$ & $94,60 \%$ & $65,90 \%$ & $82,07 \%$ \\
\hline SH3 & $98,80 \%$ & $99,10 \%$ & $99,40 \%$ & $99,10 \%$ \\
\hline SH4 & $13,30 \%$ & $14,80 \%$ & $69,10 \%$ & $32,40 \%$ \\
\hline CD 90 & $99,20 \%$ & $99,50 \%$ & $99,60 \%$ & $99,43 \%$ \\
\hline SH2 & $27 \%$ & $62,20 \%$ & $76,30 \%$ & $55,17 \%$ \\
\hline HLA ABC & $96,10 \%$ & $99,60 \%$ & $99,60 \%$ & $98,43 \%$ \\
\hline HLA DR & $0,40 \%$ & $0,94 \%$ & $1,28 \%$ & $0,87 \%$ \\
\hline \multirow[t]{2}{*}{ Marcadores } & \multicolumn{3}{|c|}{ Linhagens de FMDSC } & \\
\hline & FMDSC 5N & FMDSC $6 \mathrm{~N}$ & FMDSC $10 \mathrm{~N}$ & Media \\
\hline CD 13 & $99,30 \%$ & $99,00 \%$ & $98,00 \%$ & $98,77 \%$ \\
\hline CD 29 & $99,80 \%$ & $98,00 \%$ & $96,00 \%$ & $97,93 \%$ \\
\hline CD 31 & $2,66 \%$ & $3,00 \%$ & $4,00 \%$ & $3,22 \%$ \\
\hline CD 34 & $6,40 \%$ & $3,00 \%$ & $2,00 \%$ & $3,80 \%$ \\
\hline CD 44 & $99,70 \%$ & $84,00 \%$ & $93,00 \%$ & $92,23 \%$ \\
\hline CD 45 & $9,80 \%$ & $11,00 \%$ & $87,00 \%$ & $35,93 \%$ \\
\hline CD 73 & $95,14 \%$ & $97,00 \%$ & $94,00 \%$ & $95,38 \%$ \\
\hline SH3 & $99,04 \%$ & $97,00 \%$ & $97,00 \%$ & $97,68 \%$ \\
\hline SH4 & $38,90 \%$ & $98,00 \%$ & $93,00 \%$ & $76,63 \%$ \\
\hline
\end{tabular}




\begin{tabular}{|c|c|c|c|c|}
\hline CD 90 & $98,90 \%$ & $90,00 \%$ & $99,00 \%$ & $95,97 \%$ \\
\hline SH2 & $54,60 \%$ & $96,00 \%$ & $92,00 \%$ & $80,87 \%$ \\
\hline HLA ABC & $97,10 \%$ & $23,00 \%$ & $87,00 \%$ & $69,03 \%$ \\
\hline HLA DR & $1,90 \%$ & $4,00 \%$ & $5,00 \%$ & $3,63 \%$ \\
\hline \multirow[t]{2}{*}{ Marcadores } & \multicolumn{4}{|c|}{ Linhagens de ERC } \\
\hline & ERC 8N & ERC 9N & ERC 10N & Média \\
\hline CD 13 & $99,00 \%$ & $99,00 \%$ & $87,00 \%$ & $95,00 \%$ \\
\hline CD 29 & $99,00 \%$ & $10,00 \%$ & $89,00 \%$ & $6,00 \%$ \\
\hline CD 31 & $2,00 \%$ & $3,00 \%$ & $2,00 \%$ & $2,33 \%$ \\
\hline CD 34 & $12,00 \%$ & $6,00 \%$ & $3,00 \%$ & $7,00 \%$ \\
\hline CD 44 & $99,00 \%$ & $100,00 \%$ & $84,00 \%$ & $94,33 \%$ \\
\hline CD 45 & $96,00 \%$ & $94,00 \%$ & $49,00 \%$ & $79,67 \%$ \\
\hline CD 73 & $99,00 \%$ & $99,00 \%$ & $84,00 \%$ & $94,00 \%$ \\
\hline SH3 & $99,00 \%$ & $99,00 \%$ & $85,00 \%$ & $94,33 \%$ \\
\hline SH4 & $99,00 \%$ & $99,00 \%$ & $79,00 \%$ & $92,33 \%$ \\
\hline CD 90 & $99,00 \%$ & $99,00 \%$ & $89,00 \%$ & $95,67 \%$ \\
\hline SH2 & $99,00 \%$ & $99,00 \%$ & $84,00 \%$ & $94,00 \%$ \\
\hline HLA ABC & $99,00 \%$ & $99,00 \%$ & $83,00 \%$ & $93,67 \%$ \\
\hline HLA DR & $2,00 \%$ & $3,00 \%$ & $1,00 \%$ & $2,00 \%$ \\
\hline
\end{tabular}

Nessa etapa foram testadas variações de alguns protocolos na tentativa de aperfeiçoar o processo de obtenção das células. Particularmente, o protocolo de obtenção das FMDSC foi alterado. Ao invés de deixar o tecido previamente lavado e picotado com estiletes por 1 hora na Tripsina, o tecido passou a ser deixado por 30 min somente, para depois ser plaqueado em garrafas de $25 \mathrm{~cm}^{2}$. Foi tentado um protocolo alternativo que usava colagenase $0,1 \%$ ao invés de tripsina, sem muito sucesso. O método de cultivo agora leva somente $1 \%$ de aminoácidos não essenciais, $1 \%$ de antibióticos/antifúngicos e $15 \%$ de soro fetal bovino trocado a cada 3-4 dias.

Foi também estabelecida a curva padrão para todos os genes que foram utilizados no estudo a partir de um cDNA derivada de RNA extraído de músculo esquelético (MYF5, MYOD, MRF4, MYOG, DYST, MYHC, GAPDH e RPLP0 - Anexo 1). 
a)

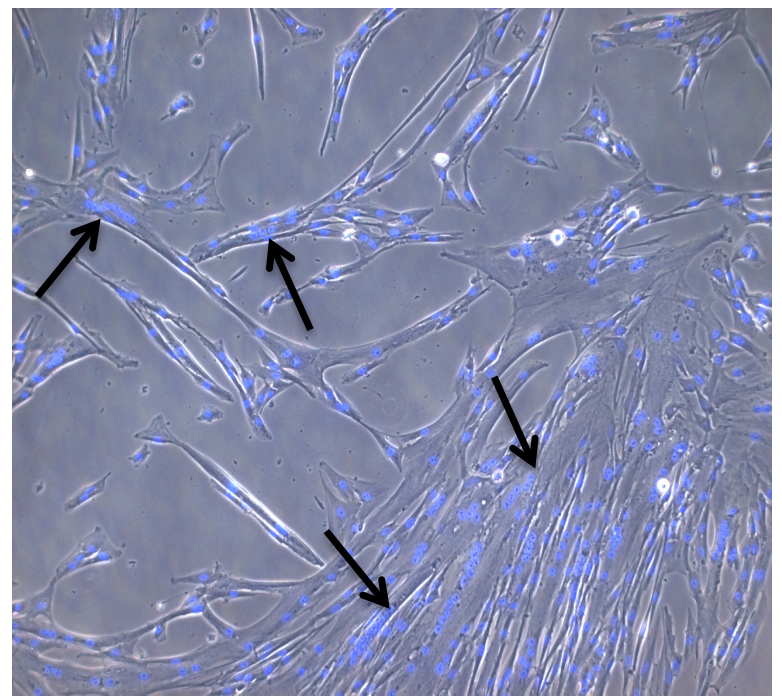

b)

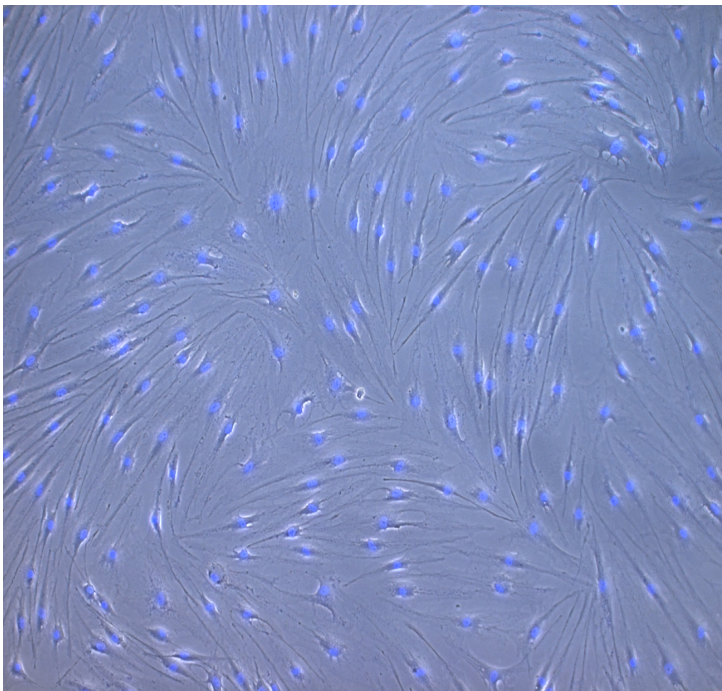

Figura 11: Imagem representativa das fusões (setas) encontradas nas linhagens de FMDSC nas passagens iniciais \#0-2 (a) e da mesma linhagem sendo diferenciada na passagem \#5 (b). 0 azul representa o núcleo corado com Hoescht 3334.100X

É digno de nota que, durante o processo de isolamento de células de FMDSC, observamos uma situação de grande relevância em nosso estudos. Nas passagens iniciais (\#0,1 ou 2) as células proliferavam muito inicialmente e fundiam formando estruturas multinucleadas conhecidas como miotúbulos de forma espontânea (figura 11). Entretanto, interessantemente essas mesmas linhagens após algumas passagens (\#4 ou 5) já não eram mais capazes de se fundir e gerar miotúbulos. Por outro lado, a capacidade de diferenciação adipogênica dessas células era evidente e aparenta não ter sido prejudicada com a expansão (figura 12).

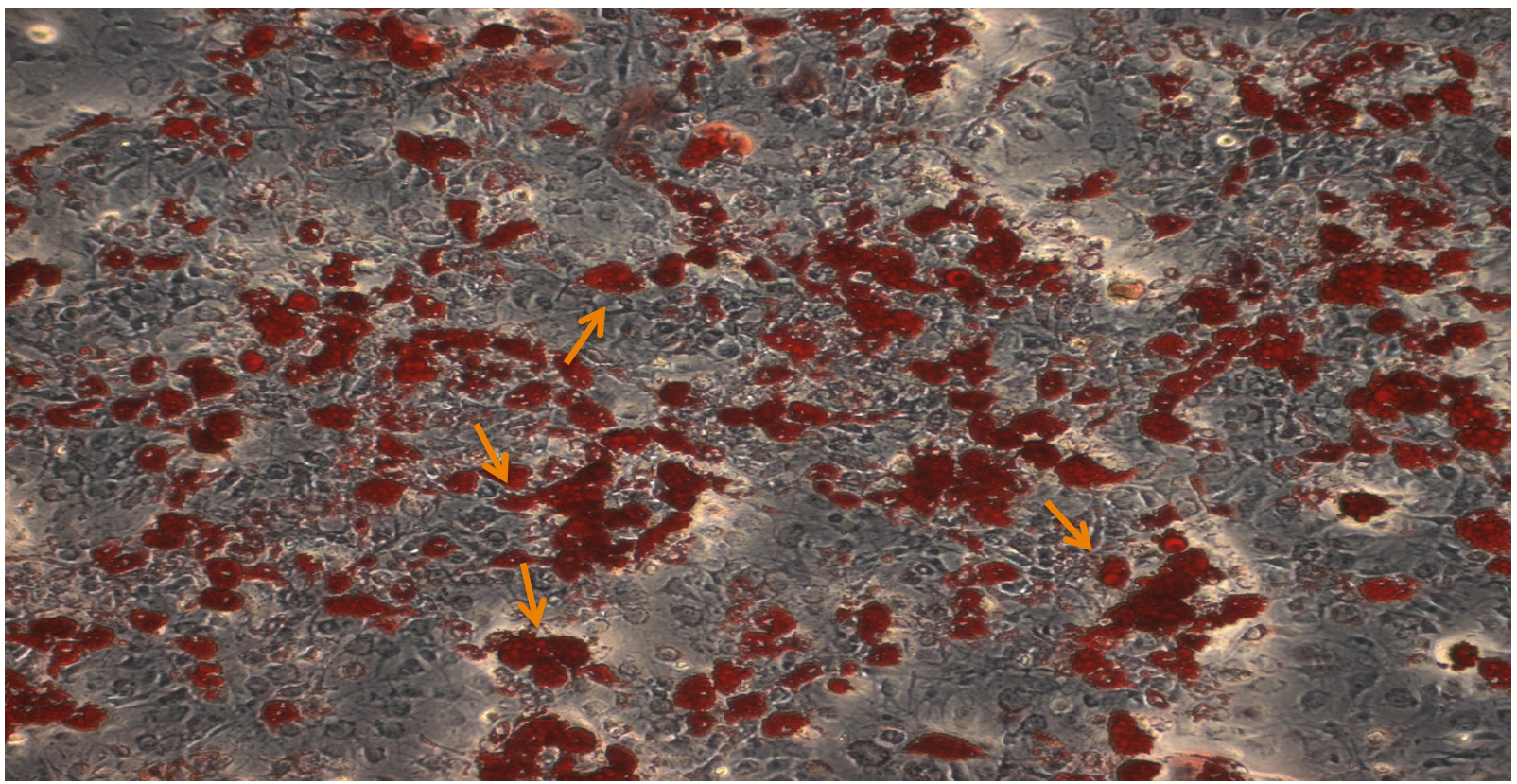

Figura 12: Imagem representativa da diferenciação adipogênica de linhagem de FMDSC nas passagens $\frac{\# 4}{5}$ 5. Setas indicam células cheias de vesículas de gordura. (100X) 
Durante o processo de diferenciação miogênica em nenhum momento foi observada fusão e formação de miotúbulos (conforme observado em controle positivo) nas linhagens e passagens previamente definidas (UCMSC, FMDSC e ERC) independente do protocolo estudado (diminuição de soro $^{80}$, adição de insulina e transferrina ${ }^{129}$ ou adição de 5 azacitidina $\left.{ }^{130}\right)$. Foram feitas também extrações de RNA em tempos diferentes durante o processo de diferenciação e os níveis de expressão dos genes previamente citados foram comparados com níveis de expressão basal da linhagem (tempo 0 de diferenciação - T0) e também com o nível de expressão de linhagens comprovadamente miogênicas. É importante citar que quando normalizamos os valores relativos de expressão dos marcadores de diferenciação miogênica pelo T0 da sua respectiva linhagem conseguimos observar um aumento pouco expressivo dos marcadores iniciais de diferenciação miogênica (figura 13).
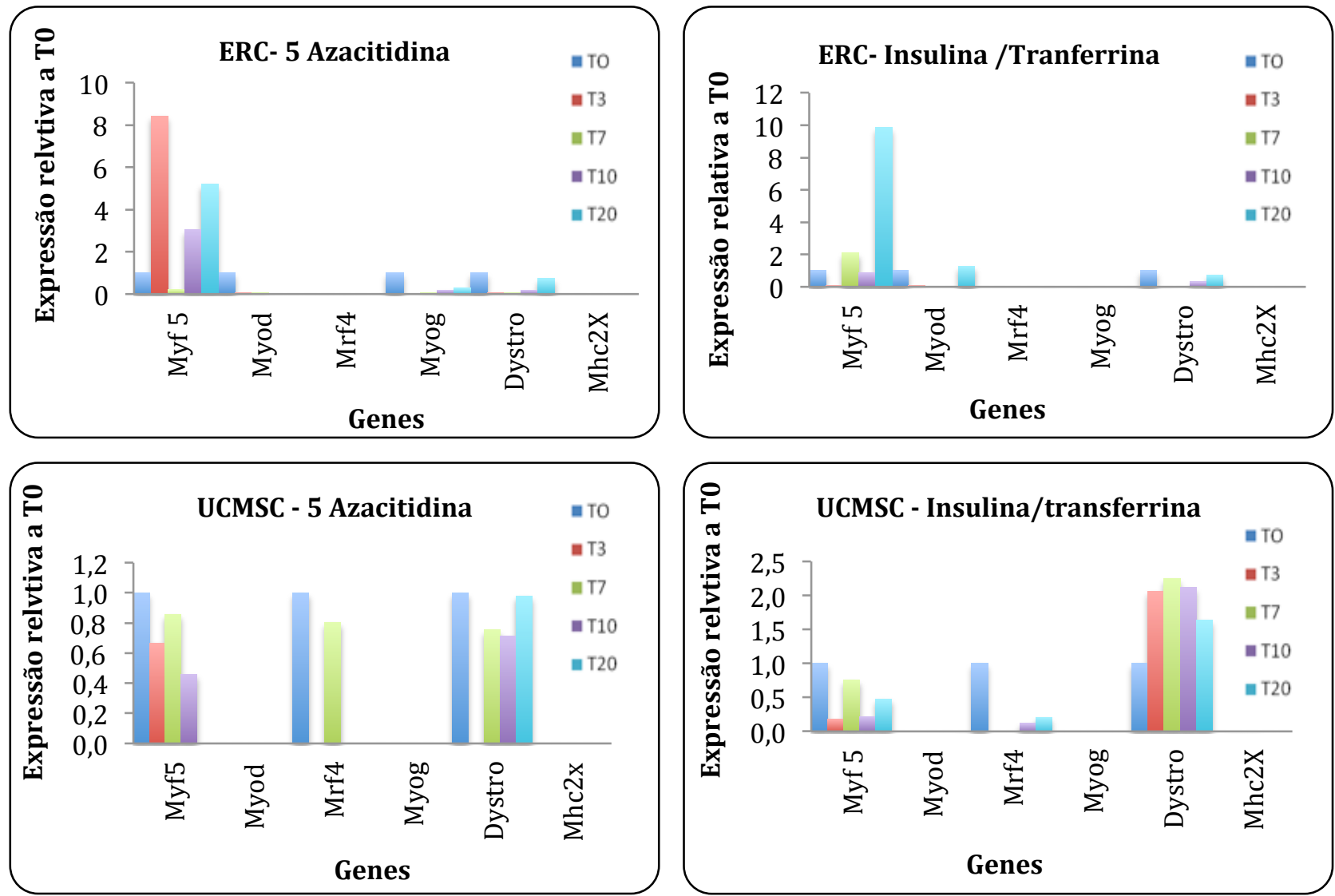

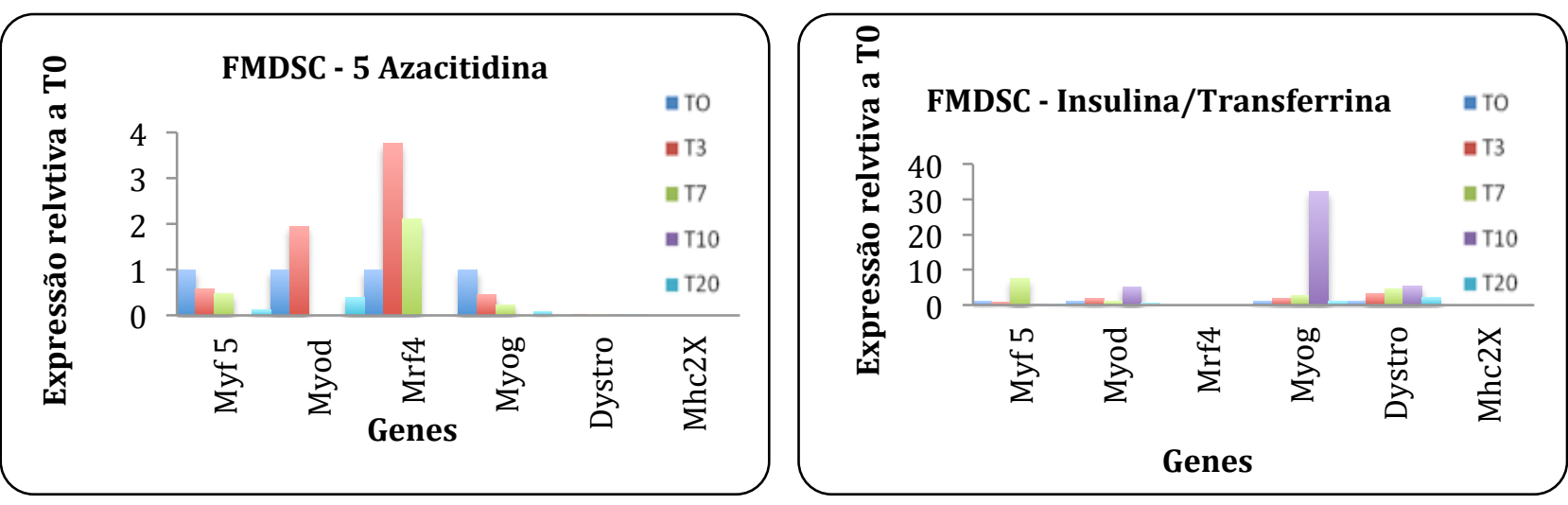

Figura 13: gráficos representativos de 2 diferentes protocolos de diferenciação por tempo. Cada grupo de barras sob cada gene (Myf5, Myod, Mrf4, Myog, Dystro e Mhc2x) representa um tempo diferente (T0, T3, T7, T10 E T20) sendo que, em cada gene, os valores foram normalizados pela expressão do T0 quando houve expressão do referido gene.

Ao compararmos esses valores com um controle positivo (mioblastos) e negativo (fibroblastos) observamos uma maior semelhança dos resultados com os controles negativos do que aos controles positivos, como verificado nos gráficos a seguir. As células foram diferenciadas usando o protocolo de redução de soro por 15 dias e posteriormente analisadas tanto com relação ao tempo 0 de diferenciação e comparadas ao controle positivo que são mioblastos diferenciados (Figura 14).

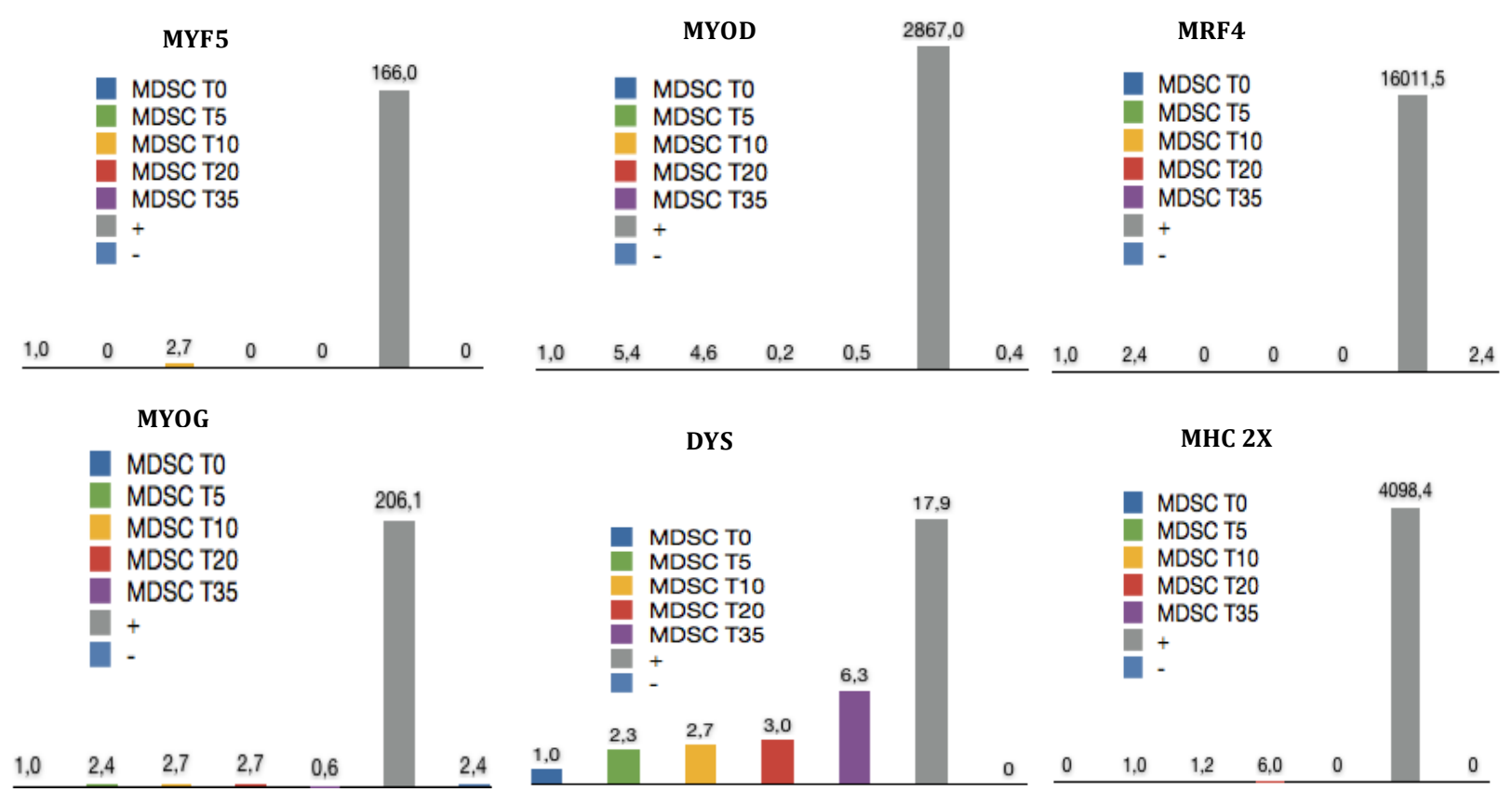

Figura 14: Linhagem FMDSC 10N representativa do padrão de expressão das diferenciações das CTMs quando comparadas com um controle positivo (barra cinza)

Através da técnica de western blot (Figura 15) podemos observar o mesmo padrão encontrado no PCR em tempo real. As membranas foram incubadas com 
anticorpos contra distrofina (DYS-1, Vector Lab, 1:100) e miosina de cadeia pesada (Milipore, clone A4.1056, 1:1000) e observou-se um aumento na quantidade de distrofina durante o processo de diferenciação, porém nenhum sinal de expressão de miosina de cadeia pesada.

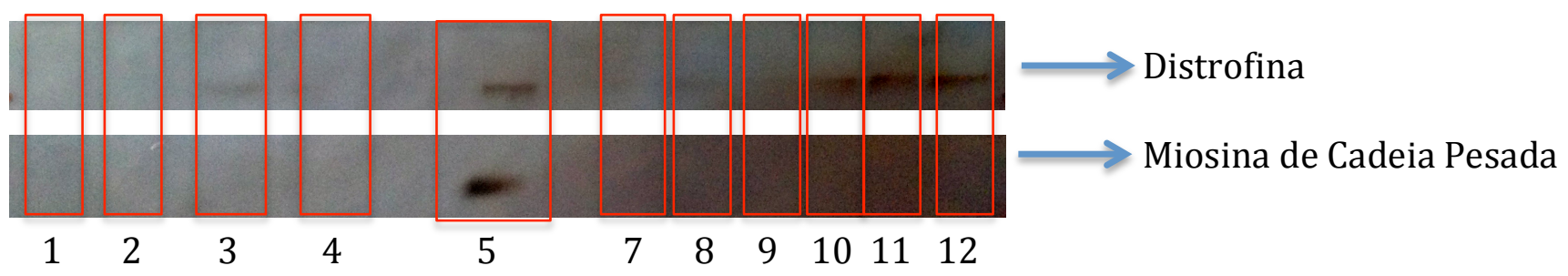

Figura 15: Western Blot representativo de 3 linhagens de CTMs de fontes diferentes e o controle positivo (posição 5). Poço 1 - Peso; Poços 2-4 (FMDSC 4N - T0, T8, T15 respectivamente); poços 7-9 (ERC - T0, T8, T15 respectivamente); poços 10-12 (FMDSC 6N - T0, T8, T15 respectivamente)

\section{IV - Discussão}

Durante o processo de isolamento e expansão de CTMs é necessário que se faça a caracterização das células. Proposto oficialmente em $2006^{131}$, esse processo inclui, dentre outras técnicas, a imunofenotipagem através de citometria com marcadores estabelecidos e a diferenciação in vitro dessas células em 3 tipos diferentes de tecidos: osso, gordura e cartilagem. Em relação a citometria, os marcadores propostos como positivos (acima de 95\% de marcação) são CD73 (a mesma proteína identificada pelos anticorpos SH3 e SH4 ${ }^{132}$ ) CD90 e CD105 (mesma proteína do $\mathrm{SH}_{2}{ }^{133}$ ). Os negativos são os mesmos já associados a outros tipos celulares como CD34 e CD45 (células-tronco hematopoiéticas), CD11 (leucócitos), CD19 (linfócitos B). Em nossos experimentos, podemos observar que a maioria dos marcadores cumprem fielmente a proposta, porém não todos (tabela 1). No entanto, alguns aspectos inerentes ao cultivo celular pareciam ser largamente 
ignorados. É o caso de marcadores regularmente usados na literatura para descreverem CTMs que não são estáveis em cultura. Sendo assim, algumas das características que eram observadas poderia ser simplesmente artefato de cultivo. Por exemplo, o marcador CD34 já foi demonstrado não ser estável em cultura ${ }^{129}$ em células derivadas de tecido muscular. Marcadores clássicos de adesão (CD90, CD29 e CD13) também são notavelmente enriquecidos em cultura de células aderentes e não necessariamente estão relacionados a algum efeito biológico de interesse. Logo, essa abordagem torna difícil caracterizar populações que sejam de fato homogêneas, pois no período de caracterização (que acontece depois do crescimento ex vivo por cerca de 4 passagens) essas células, mesmo que heterogêneas inicialmente, podem possuir um fenótipo homogeneizado simplesmente pela forma de cultivo. Isso seria mais uma fonte de variação imensurável para todo o processo. Pisani e colaboradores ${ }^{129}$ mostraram que apesar das duas populações de células musculares terem sido separadas pela sua expressão de CD34 (uma população era positiva para esse marcador enquanto a outra era negativa) após algumas poucas passagens, ambas eram CD34 negativas. Mesmo assim, uma população inicialmente CD34+ era distinguível da outra CD34quanto a capacidade de formação de tecido adiposo in vivo. Sendo assim, é possível observar que o estudo de um efeito biológico de células quando associado ao isolamento diretamente do tecido, sem prévio plaqueamento em cultura, gera resultados mais robustos e reprodutíveis. No próximo capítulo será discutida essa abordagem de forma mais direcionada.

Outra parte da caracterização das CTMs, reconhecida pela comunidade científica internacional, consiste na diferenciação in vitro para 3 tipos de células: 
osteócito, adipócito e condrócito. No entanto, como mencionado na introdução dessa tese, isso remete aos experimentos realizados in vivo e com células animais por Friedenstein e Travassoli nas décadas de 60 e 70 e que depois foram continuados por Caplan na década de 90 com células humanas em modelos animais imunocomprometidos (camundongo nude) ${ }^{99}$. Esse último estudo já mostrava restrições do potencial de diferenciação, pois foi relatado perda do potencial condrogênico após expansão in vitro. As exigências experimentais foram sendo diminuídas até finalmente se resumirem à uma avaliação de potencial meramente in vitro da capacidade de diferenciação nos 3 tipos de células anteriormente citadas ${ }^{95}$. Muitas revisões sobre o assunto já foram publicadas desde então mostrando que o real potencial das chamadas CTMs está sendo supervalorizado por se basear em ensaios in vitro que não poderiam se equiparar com situações biológica e fisiologicamente reais, as quais as células encontrariam em um ambiente in vivo ${ }^{91,100,134}$.

Outro fator, que não pode ser desconsiderado, é a falta de controles positivos e negativos devidamente caracterizados para cada uma das diferenciações propostas. A falta de quantificação impede a avaliação do potencial real de diferenciação encontrado em cada população celular. Raramente se observam tais iniciativas nos artigos atualmente publicados, o que prejudica a reprodução experimental. Também é muito discutido que exista um tipo celular que esteja abrigado nos tecidos adultos e que possa recuperar todo tipo de tecido, desconsiderando inclusive a origem dos seus precursores durante 0 desenvolvimento embrionário (como músculo, osso ou ainda tecido nervoso). Desde a divisão dos somitos, na embriogênese, culminando na sua diferenciação em 
esclerótomo e dermomiótomo, já não se observa nenhum precursor capaz de gerar tanto músculo quanto osso. A distinção de precursores entre mesoderme (camada germinativa que origina os tecidos como músculos, gordura e osso) e ectoderme (camada que dá origem a células do tecido nervoso e da epiderme) é um dos processos mais iniciais do desenvolvimento. Ao analisarmos as muitas proposições existentes na literatura em relação ao potencial miogênico sugeridos das CTMs (o maior interesse dessa tese), percebemos que são, em sua maioria, baseados em resultados não quantificados, embasados em dados frágeis (como diferenciações in vitro usando fatores demetilantes) com grandes variações metodológicas, sem a devida comparação à controles positivos associados. Todos esses fatores limitam a reprodução experimental e não permitem conclusões fidedignas. Além disso, existem ainda poucas explicações acerca do potencial in vivo relacionadas a melhoria clínica dos animais tratados. Nos experimentos dessa tese não foi possível observar a formação de miotúbulos associados à diferenciação miogênica das células do nosso interesse (UCMSC, ERG e FMDSC após a \#3)(Figura 11b), nem o aumento da expressão significativa dos marcadores associados a diferenciação miogênica por PCR tempo real, western blot e imunofluorecência. A partir desses resultados iniciais a abordagem inicial foi alterada, como visto a seguir. 


\section{Capítulo 3}

\section{I - Isolamento de células através de FACS}

Como foi concluído no capítulo anterior, observou-se que para comparar uma população de células de diferentes tecidos, seria necessário diminuir ao máximo as fontes de variação presente nas amostras. Baseados nessa observação e em publicações de diversos artigos em revistas de alto impacto 40,135,38, iniciou-se outra abordagem para a separação de células desses tecidos que baseia-se na seleção de marcadores que as células possuem in vivo, como descrito a seguir. Através de uma série de digestões enzimáticas é possível desintegrar um tecido até obter células únicas ${ }^{136}$. Após o processo de digestão, as células são incubadas com anticorpos contra os marcadores de interesse e isoladas por FACS (Fluorescent Activated Cell Sorting). A célula candidata ideal seria aquela que: a) possuísse uma propriedade migratória, isto é, depois de ser infundida por via venosa, fosse capaz de cruzar a barreira endotelial e atingir o tecido lesionado (músculos de todo o corpo); b) conseguisse fundir com miofibras dos pacientes que sofrem de distrofia muscular contribuindo ativamente para 0 processo de regeneração do tecido lesado; c) contribuísse para o reestabelecimento da quantidade de células satélites no músculo.

Dentro desse quadro, vários artigos científicos já mostraram o potencial de algumas subpopulações celulares no tecido muscular. Em um estudo específico já citado $^{129}$, foi observado que células CD34+ isoladas diretamente de músculo 
humano têm potencial adipogênico, enquanto células CD34- não. Nesse mesmo estudo também se observou que a separação de duas populações com base no marcador CD56 separou as células que apresentavam potencial miogênico (CD56+) das que não apresentavam tal potencial $(C D 56-)^{129}$. Este marcador, além de relacionado a células musculares, também foi ligado a uma pequena população de células mesenquimais de origem medular que não possuem potencial adipogênico ${ }^{137}$. Sendo assim, para doenças como as distrofias musculares, nas quais há fibrose e depósito de gordura, a seleção de células que comprovadamente não culminam na formação de depósito de gordura (CD34-) e, ainda assim, possuem um potencial miogênico (CD56+) se torna bastante interessante como alternativa para transplante.

Não podemos ignorar também um dos grandes problemas do transplante sistêmico de células que é o direcionamento para o tecido de interesse que neste caso são os músculos. Dados experimentais têm mostrado que a migração de células progenitoras ou do sistema imune para tecidos ocorre devido ao gradiente de quimiocinas, uma classe de citocinas que promovem um efeito quimiotático em células. Por isso, em um tecido onde se faz necessário a presença de células presentes na corrente sanguínea, uma alta expressão de tais quimiocinas é verificada. Um dos eixos mais estudados com relação à migração de células-tronco é o da quimiocina SDF-1 (Serum Derived Factor) e seu receptor CXCR4 (C-X-C receptor 4). Esta quimiocina, originalmente descrita como fator estimulador de células pré- $B$, está envolvida também na migração de células desde a fase embrionária ${ }^{138}$ até a adulta. Já foi descrito que músculo de animais e humanos 
distróficos super expressam SDF-1 ${ }^{139}$, o que torna interessante a busca por células que tenham o receptor CXCR4.

A partir desses estudos decidimos isolar, com equipamento FACS, de cada tipo de tecido (cordão umbilical, músculo da face e menstruação), células que fossem CD34-, CD56+, CXCR4+ e CD45- (a ausência do marcador CD45 tem sido unânime em estudos que visam à diferenciação muscular a partir de célula-tronco mesenquimais devido a sua íntima relação com células hematopoiéticas).

\section{II- Material e Métodos}

Os tecidos foram coletados conforme os termos já antes estabelecidos e processados para liberação de células únicas. Brevemente, os tecidos são extensamente lavados com PBS com 4\% de antibiótico/antimicótico (Gibco) para retirada de todo sangue e impurezas, depois cortados em pequenos fragmentos com o auxílio de estiletes. Cada grama de tecido foi incubado com $3 \mathrm{~mL}$ de colagenase tipo IA (Sigma Aldrich) a $1 \mathrm{mg} / \mathrm{mL}$ diluída em HBSS (solução estoque) e meio de cultura com $10 \%$ de soro fetal bovino (solução de digestão). O processo de digestão dura 40 min e é feito em um agitador à $37^{\circ} \mathrm{C}$ e 250 RPM. Posteriormente, centrifugar as amostras a $688 \times G$ por 10 minutos para precipitar as células. Resuspender exaustivamente o pellet em PBS com $5 \mathrm{mM}$ de EDTA até toda a solução estar homogênea. Passar pelo filtro de 70 uM ou, se necessário, antes passar no de 100 uM. Centrifugar a 500xG por 5 minutos e resuspender o precipitado em solução de lise de hemácia (Bloodlysis) por 5-10 minutos. Após, adicionar 2X o volume de PBS e passar pelo filtro de $40 \mathrm{uM}$. Centrifugar mais uma vez a 500xG por 5 minutos e resuspender em PBS para fazer a contagem das 
células. Após a determinação do número de células, resuspender as células numa concentração máxima de $10^{7}$ células/ml de PBS com $5 \mathrm{mM}$ de EDTA e $2 \%$ de soro fetal bovino (SFB). Usar a quantidade titulada de cada anticorpo conjugado (CD34, CD45, CD56 e CD146) e incubar por 30 minutos. Lavar novamente as células e colocar no tubo de citometria passando pelo filtro de $35 \mathrm{uM}$. Imediatamente antes de passar as amostras no citômetro, incubar com DAPI (5 ug/mL) para exclusão de células mortas.

As células com a marcação de interesse são separadas da população total e adicionadas na placa de interesse em uma concentração de $2 \times 10^{4}$ células por $\mathrm{cm}^{2}$. As células são mantidas na placa até atingirem a confluência $(80 \%)$ e serem tripsinizadas.

As células foram cultivadas com meio DMEM-F12 com Glutamax (Gibco) com $20 \%$ de SFB (Gibco), 1\% de aminoácidos não essenciais (NEAA - Gibco) e 1\% de antibióticos/antimicóticos (Gibco).

\section{III - Resultados}

Após várias tentativas de separação com esses marcadores, pudemos perceber que a frequência da população do nosso interesse (CD34- CD45- CD56+e CXCR4+) era muito baixa. Por diversas vezes tentamos expandir essa população e percebemos que não era possível obter a linhagem de interesse, apesar de conseguirmos outras populações como as células CD34-CD45-CD56- CXCR4(Figura 16). 

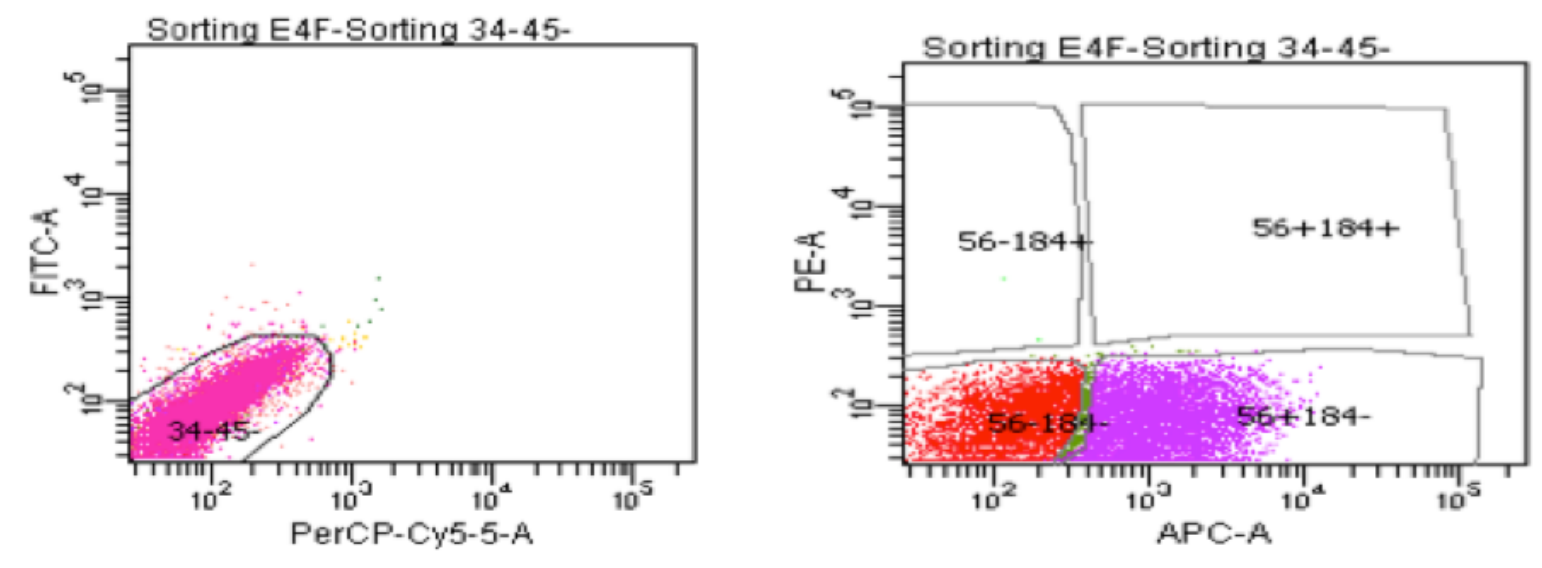

Tube: Sorting 34-45-

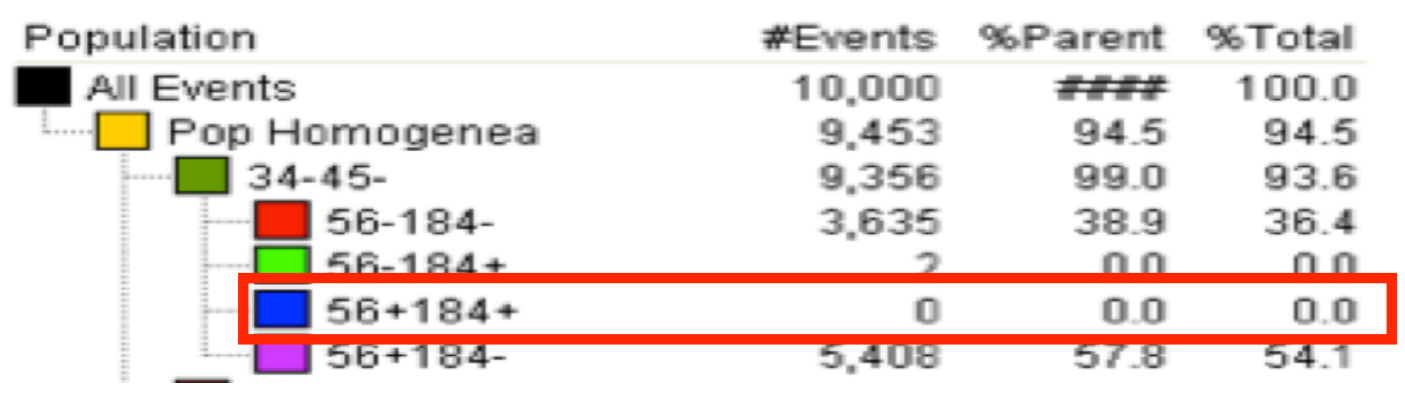

Figura 16: Estratégia de gates para separação de células de Endométrio. Notar que no segundo gráfico não aparece nenhuma população referente a CD56+e CD184(CXCR4)+.

\section{IV - Discussão}

Nesta fase do nosso projeto a estratégia de separação de células se tornou algo fundamental mas não conseguimos isolar a população que decidimos escolher através dos marcadores CXCR4+, CD56+, CD34- e CD45-. Na literatura encontramos muitos artigos descrevendo o isolamento de células CXCR4+ da medula ou do sangue ${ }^{140}$ e muitos estudos relacionando essa via (SDF-1/CXCR4) ao potencial de recrutamento de células em tecidos lesados. Com relação a busca de células miogênicas, pudemos observar que, em um estudo singular, as análises minuciosas em busca de progenitores robustos miogênicos em célula da medula óssea, em células-tronco hematopoiéticas e no músculo propriamente dito levaram a conclusão de que, além do músculo, não há (nos tecidos em questão) nenhum precursor muscular relevante. Foi possível ainda encontrar no músculo de camundongos um tipo celular definido por uma série de marcadores, dentre eles o 
CXCR $4^{141}$. Este estudo culminou ainda numa publicação posterior mostrando as propriedades de regeneração e característica de verdadeiras células tronco musculares da população anteriormente identificada ${ }^{142}$.

Em humanos, no entanto, ainda não se tem marcadores tão bem definidos e a simples transposição daqueles encontrados em camundongos nem sempre é possível. Por exemplo, em camundongos o marcador CD34 no músculo define uma população de células satélites com alto potencial miogênico ${ }^{38}$. Já em humanos o marcador CD34 está associado à células intersticiais com potencial adipogênico ${ }^{129}$. Em face à nossa proposta inicial de comparação de potencial miogênico de diferentes tecidos, acabamos por encontrar limitações desse mesmo nível. Da mesma forma, não seria plausível imaginarmos que um marcador qualquer em um tecido defina o mesmo tipo celular em um outro tecido. Por exemplo, o marcador CD56 que no músculo humano caracteriza uma célula altamente miogênica ${ }^{35}$ em outros tecidos representa populações completamente diferentes como células Nk (do inglês Natural killers) no sangue ${ }^{143}$ ou CTM sem potencial adipogênico na medula $^{137}$. Portanto, para respondermos à nossa questão comparativa, seria importante encontrarmos um tipo celular que fosse comum à todos os tecidos e que possuísse comprovado potencial miogênico. Portanto, nos voltamos para o tipo celular que mais se encaixava nas qualidades necessárias para o nosso estudo, a célula de pericito, a qual será tema do próximo capítulo dessa tese. 


\section{Capítulo 4}

\section{I - Isolamento de células de pericito}

O conceito de um progenitor canônico é associado à células que têm uma plasticidade considerada ortodoxa, ou seja, que obedece ou se mantém dentro do contexto do órgão/sistema da qual foi retirada. Por exemplo: as células-tronco de medula óssea têm um potencial validado com experimentos in vivo para se diferenciar em gordura, osso, condrócito, células reticulares e estromais. Todas essas diferenciações são consideradas ortodoxas porque estão dentro do contexto do sistema da medula óssea ${ }^{144}$. Uma diferenciação das células de medula em músculo esquelético, como foi verificada ${ }^{37,82}$ foge da ortodoxia do sistema e sugere mecanismos desconhecidos que são dignos de estudo. A noção de que a medula óssea contém células com potencial miogênico, ainda que em pouca quantidade ${ }^{108}$, induziu a procura de progenitores não canônicos que tivessem alguma relação com a medula óssea. Iniciou-se uma busca por um progenitor que, durante o desenvolvimento embrionário, fosse anterior ao desenvolvimento das células-tronco hematopoiéticas $(\mathrm{CTH})$ e aos tecidos sólidos da mesoderme.

A observação de que as células-tronco hematopoiéticas (que no adulto se localizam na medula óssea) são derivadas de uma população específica de progenitores endoteliais localizados na região ventral da aorta dorsal (região conhecida como AGM - do inglês Aorta Gonad Mesonephros - figura 17) sugeria 
uma hipótese interessante que outras células progenitoras/tronco poderiam estar

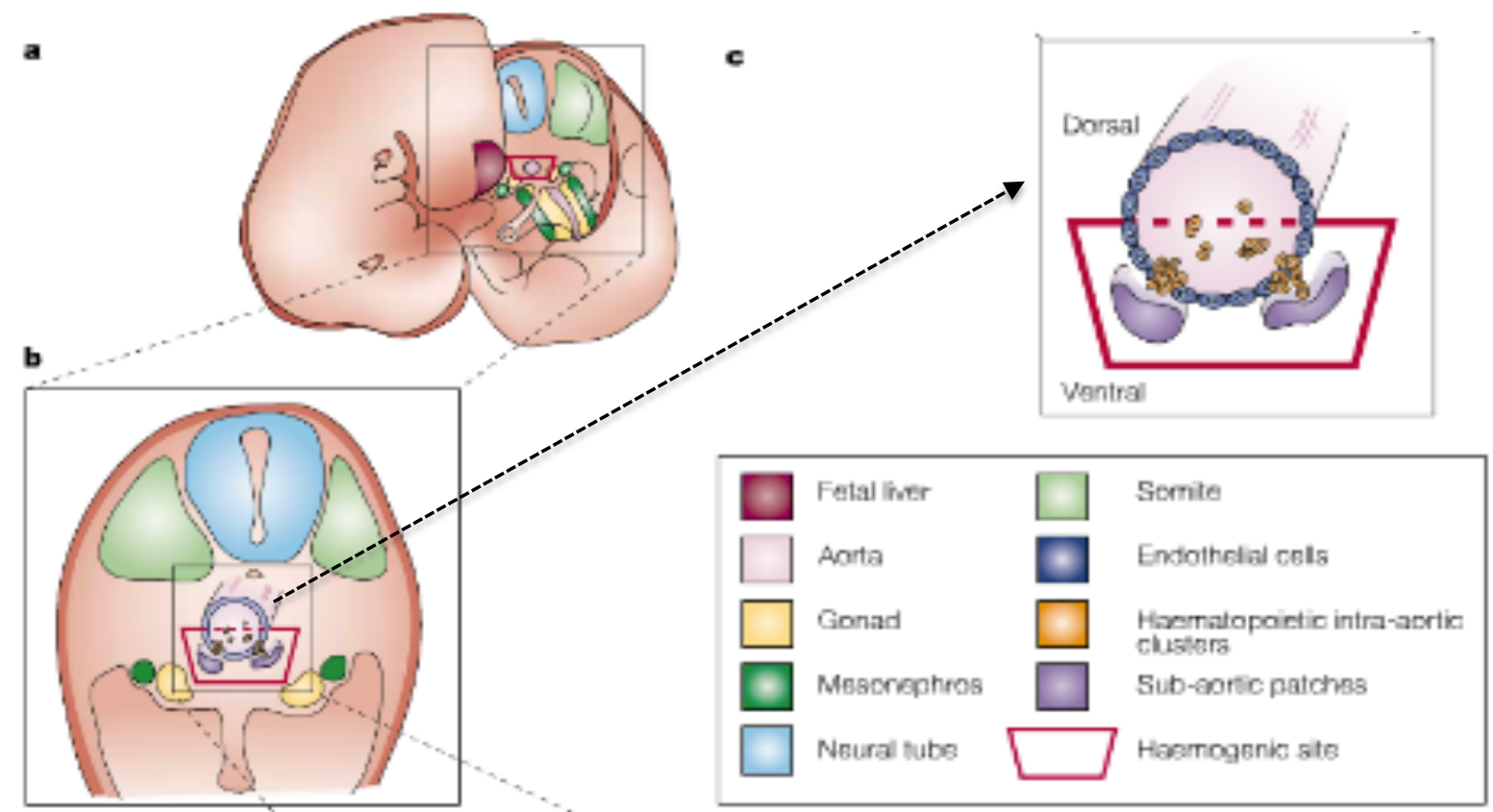

Figura 17: Detalhe da região de interesse na busca de um precursor comum às CTHs e tecidos sólidos mesodérmicos. Em relação à figura, acredita-se que divisões assimétricas das células na parte evidenciada pelo trapézio gerariam CTHs de uma lado (porção luminal) e do outro células que contribuem para a fase sólida de tecidos mesodérmicos ${ }^{3}$. Figura retirada de Godin, $2002^{5}$

presentes em regiões próximas no embrião ${ }^{3}$. Essa hipótese foi testada e validada

através de experimentos feitos com populações (clonais e não clonais) dessa região ${ }^{86}$. Estudos ainda mostraram que essas células (denominadas Mesoangioblastos - em contraposição aos hemangioblastos, que dão origem às células-tronco hematopoiéticas), quando transplantadas de codornas ou camundongos para embriões de galinha contribuem não só para formação de músculos esqueléticos e cardíaco, mas também de osso, condrócitos e células de vasos sanguíneos ${ }^{87}$. Sendo assim, foi identificada um tipo de célula, ainda que somente no contexto embrionário, que poderia contribuir para a formação de tecidos no indivíduo adulto como demonstrado na figura 18.

Esses experimentos, portanto, permitiram conclusões esclarecedoras sobre o potencial de diferenciação não canônico das células de medula óssea. Tais 
conclusões eram: progenitores vasculares e progenitores de tecidos mesodérmicos extra-vasculares (como músculo, osso, cartilagem e gordura) podiam ser encontrados na mesma região (aorta dorsal) durante o desenvolvimento embrionário e, por inferência, possivelmente durante a vida adulta nas regiões vasculares. Dessa forma, muitos grupos passaram a procurar esse tipo celular nos tecidos

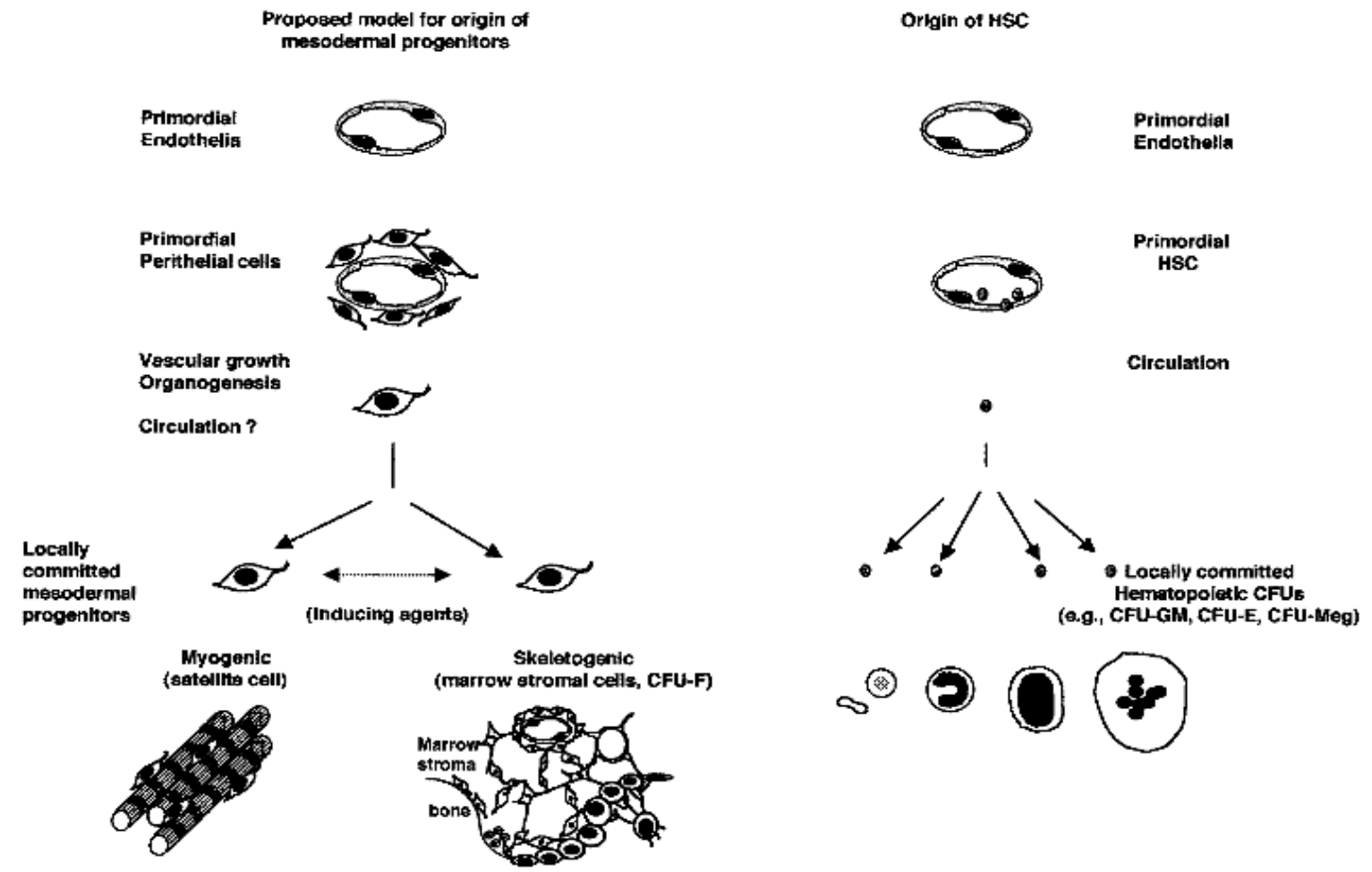

Figura 18: Proposta de diferenciação as células derivadas da aorta dorsal. Imagem retirada de Bianco, 1999

mesodérmicos. Desde 2003, já se procuravam por células relacionadas ao sistema vascular que poderiam ter esse potencial, pois muitas evidências apontavam para uma relação íntima entre quantidade de células-tronco e vascularização dos tecidos.

Vários estudos, com diferentes abordagens, identificaram as chamadas células perivasculares, ou pericitos, como sendo verdadeiramente as células com potencial de diferenciação no tecido adulto. Células separadas por sua marcação com o anticorpo STRO-1 (que tem grande capacidade de diferenciação in vivo) apresentam posição perivascular in situ em cortes de medulas e de polpa 
dentária $^{145}$ e expressão compatível com a de precursores endoteliais (alfa-actina, CD146 e ausência de von Wildebrand Factor). Nesse mesmo ano, um estudo realizado em camundongos modelo para distrofia muscular de cinturas (deficientes em uma proteína estrutural chamada alfa-sarcoglicana), mostraram que a terapia com mesoangioblastos (derivados tanto de embriões como de músculos de camundongos jovens e nesse segundo caso as células são chamadas pericitos) obteve ótimos resultados. Essas células foram capazes, quando injetados pela artéria femoral dos animais, de: a) atingir os músculos migrando através da barreira endotelial; b) fundir com as fibras existentes; c) expressar as proteínas deficientes e d) promover melhora clínica nos animais ${ }^{88}$. É interessante notar que nesse estudo células satélites foram usadas como comparação para mostrar a deficiência na migração do vaso para o tecido, já que isso é reconhecidamente uma deficiência deste tipo celular.

Em sequência, foi também descrita a presença e forma de cultivo de pericitos de músculos humanos ${ }^{80}$. Essas células, assim como as células satélites, são miogênicas in vivo e in vitro. No entanto, possuem diversas características diferentes de células satélites como: forma de cultivo, dinâmica de crescimento e diferenciação, morfologia, padrão de expressão gênica e atividade de telomerase ${ }^{80}$. Dessa forma, os pericitos se caracterizam como uma fonte alternativa de precursor miogênico em músculo de origem humana (provavelmente o representante humano das células anteriormente descritas por Sampaolesi et al 2003 e 2006 em camundongos e cães respectivamente). Nos estudos de descrição dessa população, observou-se uma alta expressão de marcadores compatíveis de células de pericito, como CD146 e fosfatase alcalina (no músculo, a única célula positiva 
para ALP - do inglês Alcaline Phosphatase - é o pericito). Depois de separadas por FACS pela marcação de ALP, estas células foram expandidas ex vivo e também demonstraram capacidade de migrar através dos capilares, atingir o músculo de animais imunodeficientes e distróficos (mdx-SCID) dando sinais de melhoras clínicas. Posteriormente, o mesmo grupo demonstrou, através da utilização de genes repórteres em animais transgênicos, que essas células do pericito participam de processos naturais de desenvolvimento e regeneração miogênica e que, portanto, são consideradas progenitores musculares naturais ${ }^{109}$.

As evidências sobre o potencial dessas células continuaram crescendo. Sachetti et al ${ }^{10}$ também demonstrou que, no caso de células-tronco derivadas da medula óssea, o potencial de formação de medula heterotópica residia em células com alta marcação para CD 146 (pericito). Através de experimentos muito bem controlados e robustos, foi possível mostrar que essas células (e não outra sub população estudada) são capazes de não somente formar uma medula em um ambiente estranho às condições ideias (transplante heterotópico) como também de serem transplantadas de forma seriada para outros animais, dando evidências fortes de que o potencial tronco era intrínseco à elas e não ambiente dependente ${ }^{110}$.

Nesse momento, muitos estudos indicavam a existência de células em diversos tecidos, obtidas e selecionadas através da sua aderência às placas de cultivo (CTMs) e com propriedades de diferenciação in vitro ${ }^{101}$. Alguns autores propunham uma origem comum à todas essas células, porém, as evidências ainda não existiam. Em 2008, Crisan et $a^{\beta 0}$ conseguiram mostrar que os pericitos podiam ser encontrados em diversos tecidos adultos e fetais não relacionados como pâncreas, cérebro, gordura, placenta e músculos. Em todos estes tecidos, as 
células de pericitos foram identificadas por sua marcação de CD146 associada ao posicionamento próximo de vasos. Após essa identificação, os pesquisadores mostraram ser possível isolar e cultivar essas células ex vivo de todos os tecidos estudados. Surpreendentemente, todas essas células apresentavam potencial miogênico e osteogênico in vivo e potencial adipogênico e condrogênico avaliado in vitro $^{90}$,

Analisando toda a literatura, percebemos então a grande possibilidade de estudo utilizando as células do do pericito, uma vez que estas células já foram caracterizadas, possuem um arcabouço teórico-científico embasado, podem ser encontrado em diferentes tecidos e tem potencial miogênico comprovado. Por isso, essas células tornam-se uma ferramenta propícia para uma comparação entre tecidos. Decidimos também estudar tecidos retirados da mesma pessoa, diminuindo assim a variabilidade genética que poderia comprometer a análise dos dados.

\section{II- Material e Métodos}

Os tecidos foram coletados mediante cirurgias de histerectomia total abdominal após termo de consentimento . Nessas cirurgias era possível a coleta de 4 tipos de tecidos: músculo, gordura, trompa e endométrio. Tínhamos a seguinte média de peso de cada material por coleta:

Gordura: $10 \mathrm{~g}$

Endométrio: $\sim 3 g$

Trompa: $2 \mathrm{~g}$

Músculo: ${ }^{1 g}$ 
Os tecidos foram coletados em meio de cultura e processados em até $24 \mathrm{~h}$ para liberação de células únicas. Segue o resumo da técnica:

Os tecidos são extensamente lavados com PBS com 4\% de antibiótico/antimicótico (Gibco) para retirada de todo sangue e impurezas, depois cortados em pequenos fragmentos com o auxílio de estiletes. Cada grama de tecido é incubado com $3 \mathrm{~mL}$ de colagenase tipo IA (Sigma Aldrich) a $1 \mathrm{mg} / \mathrm{mL}$ diluída em meio de cultura com $10 \%$ de soro fetal bovino (solução de digestão). O processo de digestão dura 40 min e é feito em um agitador à $37^{\circ} \mathrm{C}$ e 250 RPM. Posteriormente, centrifugar as amostras a 688xG por 10 minutos para precipitar as células. Resuspender exaustivamente o pellet em PBS com 5mM de EDTA até toda a solução estar homogênea. Passar pelo filtro de 70 uM ou, se necessário, antes passar no de 100 uM. Centrifugar a 500xG por 5 minutos e resuspender o precipitado em solução de lise de hemácia (Bloodlysis) por 5-10 minutos. Após, adicionar 2X o volume de PBS e passar pelo filtro de 40 uM. Centrifugar mais uma vez a 500xG por 5 minutos e resuspender em PBS para fazer a contagem das células. Após a determinação do número de células, resuspender as células numa concentração máxima de $10^{7}$ células $/ \mathrm{mL}$ de PBS com $5 \mathrm{mM}$ de EDTA e $2 \%$ de soro fetal bovino (SFB). Usar a quantidade titulada de cada anticorpo conjugado (CD34, CD45, CD56 e CD146) e incubar por 30 minutos. Lavar novamente as células e colocar no tubo de citometria passando pelo filtro de $35 \mathrm{uM}$. Imediatamente antes de passar as amostras no citômetro, incubar com DAPI (5 ug/mL) para exclusão de células mortas.

A células com a marcação de interesse são separadas da população total e adicionadas na placa de cultura numa concentração de $2 \times 10^{4}$ células por $\mathrm{cm}^{2}$. As 
células são mantidas na placa até atingirem a confluência (80\%) e serem tripsinizadas (Tripsina-EDTA 0,25\% - Gibco). Para cultivo das células de pericito utilizamos o meio EBM-2 (Lonza) até a primeira passagem e também da $4^{\circ}$ passagem em diante (associado aos fatores de crescimento, conforme a orientação do fabricante) e o meio era trocado a cada 2 dias. Para que todos os experimentos fossem realizados com as mesmas linhagens, as células foram usadas em todos os experimentos entre as passagens 7-10. No total, somente conseguimos obter as 4 linhagens de uma única paciente (19F). No entanto, pudemos também obter linhagens de pericitos de 4 outras pacientes de 3 tecidos diferentes (gordura, trompa e endométrio). O tecido muscular se mostrou limitado, principalmente pela quantidade de material disponível por paciente (na média $1 \mathrm{~g}$ de músculo). Os experimentos de PCR tempo real e western blot foram feitos com todos as linhagens disponíveis e apresentaram os mesmos resultados. Já os experimentos de imunofluorescência e injeções in vivo somente foram realizados com as células da doadora 19F.

As diferenciações miogênicas foram induzidas a partir da mudança do meio de crescimento para DMEM-F12 Glutamax (Gibco) com $2 \%$ de soro de cavalo (Gibco) por um período máximo de 15 dias. Para este experimento foram cultivadas mioblastos humanos (primários e comerciais) como controle positivo de diferenciação e fibroblastos de pele (de cultura primária) como controle negativo. Foram feitas análises de expressão por PCR tempo real, western blot e imunofluorescência. Para extração de RNA foram usados os Kits miRNAasy (Quiagen). Para a transcrição reversa foi usada a enzima Super Script III (Life Technologies). $5 \mathrm{ng}$ de cDNA foram usados nas reações de PCR em tempo real 
com o Sybr Fast (Roche) na máquina Light Cycler 480 II (Roche). Para Western Blot e imunofluorescência usou-se anticorpo contra Distrofina (DYS-1 - Vector, Abcam 15277) e miosina de cadeia pesada 2x (MF-20, A4.1056 - Developmental Studies Hybridoma Bank). Para a revelação das membranas usou-se o reagente ECL Prime (GE)

Para experimento in vivo injetou-se cerca de 20 animais (DKO mdx/utrofina) por grupo (veículo, fibroblasto, mioblasto, pericito derivado de endométrio, pericito derivado de trompa, pericito derivado de gordura e pericito derivado de músculo) com injeções intraperitoneais semanais de $10^{6}$ células vivas por 2 meses. A colônia desse animais é mantida em homozigose para a mutação no gene da distrofina (animais MDX são férteis) e em heterozigose para a mutação no gene da utrofina (homozigotos DKO são inférteis). Portanto, a cada ninhada (progenitores heterozigotos), os animais são genotipados com menos de 1 mês de vida e, pela expectativa mendeliana, apenas $1 / 4$ dos animais apresentam a mutação em homozigose e têm sinais clínicos da doença. Posteriormente esses animais foram randomicamente alocados nos 7 diferentes grupos experimentais. Foi também acompanhado um grupo de 36 animais controles selvagens ou heterozigotos para a mutação do gene da utrofina (irmãos das mesmas ninhadas usadas para os animais afetados) durante todo o experimento. Foram ainda realizados teste físicos antes e depois das injeções para avaliar o quadro clínico dos animais. Os testes escolhidos para avaliação foram:

a) Deambulação: os animais têm suas patas traseiras pintadas com tinta e são colocados num corredor estreito com uma folha branca que é marcada com as passadas dos animais. Cada animal tem 
sua passada registrada por 3 vezes consecutivas. Após, o valor da média das suas passadas é normalizado pelo tamanho do animal.

b) Grip: cada animal tem as suas patas dianteiras arrastadas sobre uma grade conectada a um dinamômetro digital que marca o maior valor de força feito contra o arraste por 6 vezes consecutivas. A média dos 3 maiores valores representam o resultado de cada animal. Os valores também são normalizados pelo tamanho do animal.

c) Rota Rod: Os animais são colocados em estruturas cilíndricas que giram no seu próprio eixo com incremento de velocidade. O tempo de permanência no aparato reflete a habilidade do animal de superar uma condição adversa que exige equilíbrio e mobilização de sua musculatura esquelética. Consideram-se a média dos valores de 3 tentativas consecutivas.

Todos os testes de comparação entre antes e depois ou entre animais CONTROLE e VEÍCULO foram feitos com testes-t pareados e não pareados, respectivamente. Uma vez determinado a validade do uso dos dados coletados num determinado teste físico, todas as amostras foram comparadas entre si com teste ANOVA de múltiplos testes.

Como animais MDX/utrofina possuem um fenótipo grave e consequente morte prematura, avaliar se a expectativa de vida desses animais era alterada pelo transplante das células é fundamental. Para isso, aguardamos que os animais morressem de forma natural durante o período experimental. Os valores de sobrevivência foram plotados e calculados no software Graph Prism 6. Os valores 
de cada linhagem foram colocados em forma de tabela e uma comparação entre curvas de sobrevivência foi feita utilizando o teste de log-rank. Para análise de duas curvas entre si foi utilizado o teste de Gehan-Breslow-Wilcoxon e feita a correção de Bonferroni. Foram analisadas as curvas de sobrevivência tanto durante o tratamento (que admite como sucesso o animal permanecer vivo até o final de 2 meses de tratamento) quanto após a morte do animal (independente de quanto tempo após o tratamento ela acontecia).

Após a morte dos animais, eram coletados o fígado, baço, músculo, pulmão e rins dos animais para verificar a presença de DNA humano nesses órgãos. Esses tecidos foram preservados em $1 \mathrm{~mL}$ de solução de RNAlater (Ambiom) e deixados 1 dia à $4^{\circ} \mathrm{C}$ e depois transferidos para $-80^{\circ} \mathrm{C}$ até serem processados. Para extração de DNA das amostras de tecidos foi utilizado a solução DNAzol (Life Technologies) e o protocolo orientado pelo fabricante. Um máximo de $50 \mathrm{mg}$ de cada tecido foi homogeneizados com beads de cerâmica no Precellys por 5 segundos a 5000 RPM por 2 vezes. Para o músculo especificamente, foram usados 6 rotações de 6000 RPM por 20 segundos.

O protocolo de PCR humano foi baseado em duas publicações independentes. Foram usados 3 pares de primers dentro da mesma reação (multiplex). Um par de primers identifica tanto DNA humano quanto de camundongo $^{146}$ e amplifica um fragmento de $215 \mathrm{pb}$; um outro par de primers amplifica somente DNA de camundongo e o fragmento tem $189 \mathrm{pb}^{146}$ e por fim, um último par de primers amplifica um fragmento de 140 pb de DNA humano ${ }^{147}$. Sendo assim, dentro da mesma reação, podemos ter um controle positivo da reação além de identificar quais os tipos de DNA que temos na amostra. 


\section{III - Resultados}

Após a dissociação dos tecidos em células únicas e a marcação com os anticorpos de interesse, passamos as células pelo FACS e optamos pela seguinte estratégia de separação:

1- $\quad$ Primeiramente, exclusão de Doublets (eventos que indicam 2 células ao invés de uma)

2- $\quad$ Seleção das células que não incorporaram DAPI em seus núcleos (células viáveis)

3- $\quad$ Escolha das células que são CD34 (Percp. Cy5.5) e CD45 (Fitc) negativas

4- $\quad$ Seleção das células CD56 (APC) negativas e por fim 146 (PE) positivas.
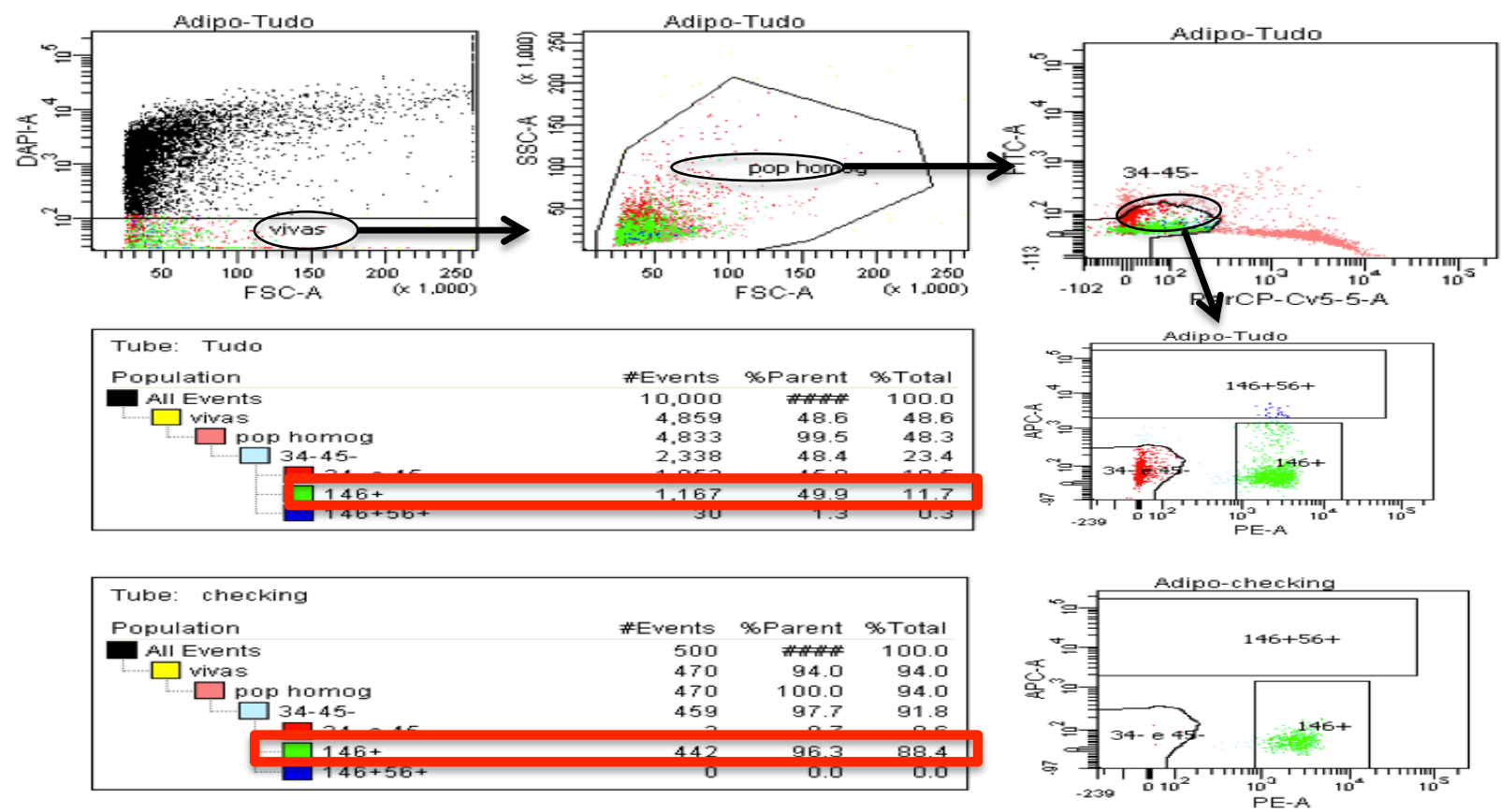

Figura 19: População de interesse: somente células vivas (gráfico 1), homogêneas (gráfico 2), 34-45(gráfico 3) e 56-146+ (gráfico 4). Na segunda tabela com o gráfico ao lado, notar o enriquecimento 
Somente no tecido muscular foi feita a separação de células CD56+ também, pois são mioblastos. Dessa forma tínhamos um bom controle de separação celular. Após o período de separação, a eficiência da mesma era verificada usando uma alíquota das células comprovando o seu sucesso. Na figura 19 abaixo podemos verificar os gráficos representativos da linhagem de gordura da amostra 19F (o gráfico de todas as linhagens é mostrado no anexo 2).

Após a separação, as células apresentavam uma morfologia fibroblastóide e crescimento lento. No entanto, após a segunda semana, as células já cresciam rapidamente, atingindo uma taxa de crescimento compatível com aquela já descrita em Crisanl $^{90}$. Ao atingir a passagem de interesse (\#7) para a realização dos experimentos, calculamos o tempo médio de population doubling (PD) que é uma medida importante na taxa de crescimento celular. O resultado se encontra na tabela 2.

Tabela 2: Tempo necessário para a duplicação das populações de pericito listadas abaixo

\begin{tabular}{cc}
\hline Linhagem & Tempo PD (em horas) \\
\hline Fibroblasto & 33,6 \\
\hline Mioblasto & 63,6 \\
\hline Pericito de Endométrio & 35 \\
\hline Pericito de Trompa & 56,2 \\
\hline Pericito de Gordura & 64,2 \\
\hline Pericito de Músculo & 67,2 \\
\hline
\end{tabular}


Como se pode notar na figura 20 , nenhuma das linhagens induzidas à diferenciação atingiram, de forma satisfatória, os níveis de expressão gênica observados nos mioblastos comerciais em nenhum dos genes analisados. Somente a expressão de distrofina pode ser observada ligeiramente aumentada em algumas linhagens. Para controle do nosso experimento, também incluímos linhagens de mioblastos não comerciais estabelecidas em nosso laboratório por FACS, separadas por sua expressão de marcadores de células satélites (células CD56+). Nesse caso, podemos ver que essas linhagens respondem de forma muito semelhante a linhagem comercial.
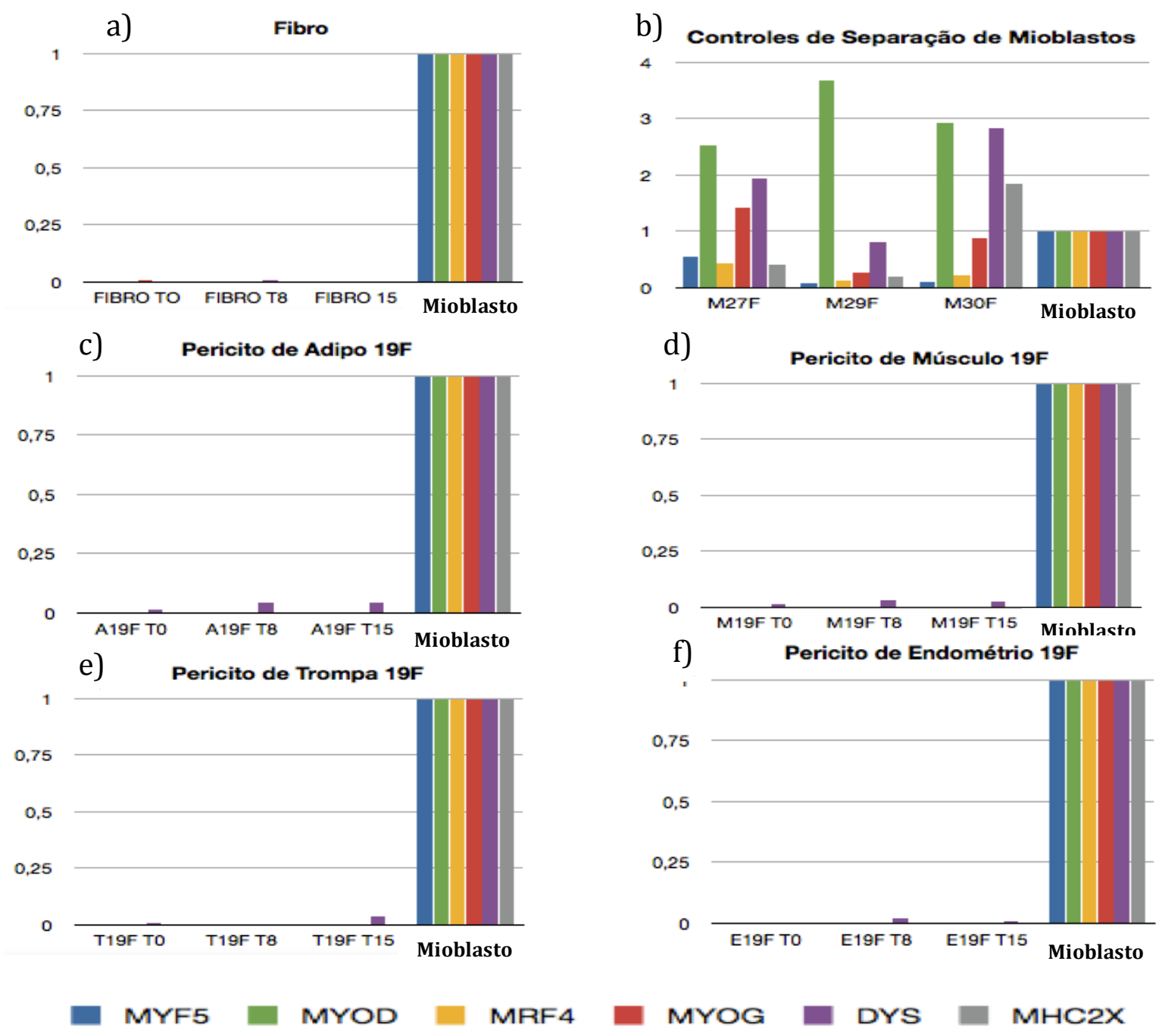

"Figura 20: Padrão de expressão das linhagens submetidas a diferenciação miogênica in vitro. A Fibroblasto, B- controle positivo de mioblastos separados por FACS; C - Pericito de Gordura; DPericito de Músculo; E- Pericito de Trompa; F- Pericito de Endométrio. "Mioblastos" representa uma linhagem comercial que nos serviu de controle positivo 
Experimentos de western blot também confirmam os resultados observados no PCR em tempo real (figura 21). Após a revelação das membranas pudemos perceber que as linhagens de fibroblasto e pericito não apresentavam expressão de miosina de cadeia pesada, enquanto as linhagens de mioblastos comercias e não comerciais, sim. Da mesma forma pudemos notar uma expressão de distrofina em algumas linhagens de pericito, corroborando o dado do PCR em tempo real.
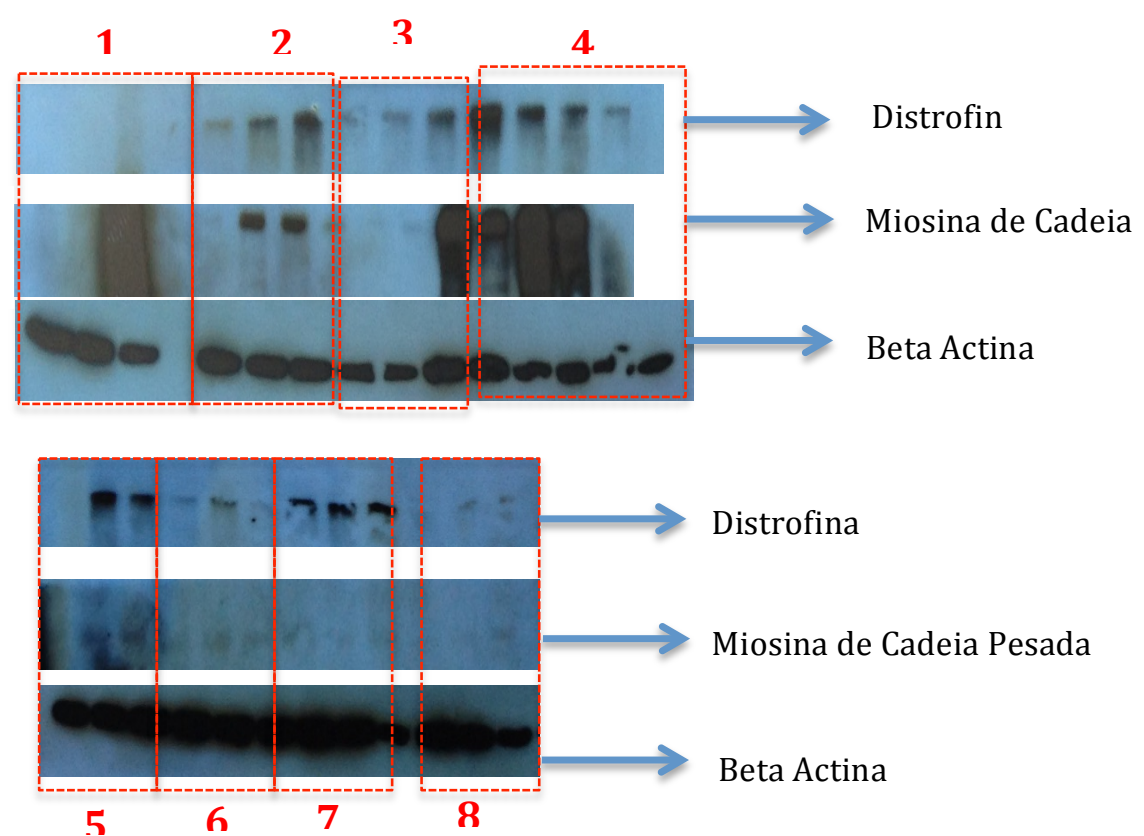

Figura 21: Western Blot das diferenciações de diversas linhagens. 1- Fibroblasto (T0, T8, T15); 2Mioblasto M (T0, T8 e T15); 3- Mioblasto M22F (T0, T8, T15); 4- Diferenciação final de 4 linhagens independentes de mioblasto; 5- Pericito de Trompa 19F (T0, T8, T15); 6- Pericito de Endométrio 19F (T0, T8, T15); 7- Pericito de Gordura 19F (T0, T8, T15); 8- Pericito de Músculo 19F (T0, T8, T15). Detalhe do arrasto em um dos poços referente ao Fibroblasto no gel de miosina de cadeia pesada é devido ao peso molecular - no gel da beta actina e distrofina este se encontra na posicão 4. mas no gel da Miosina de cadeia pesa se encontra na posicão 3.

Por fim, as imunofluorescências confirmaram o que os experimentos anteriores indicaram. Os controles positivos (mioblastos) formavam as estruturas sinciciais típicas de uma diferenciação miogênica e mostravam marcação positiva para distrofina/desmina e miosina de cadeia pesada. Já nas diferenciações das populações de pericito e de fibroblasto não foi observado fusão e nem marcação para as proteínas de interesse conforme se observa na representação da figura 22. 

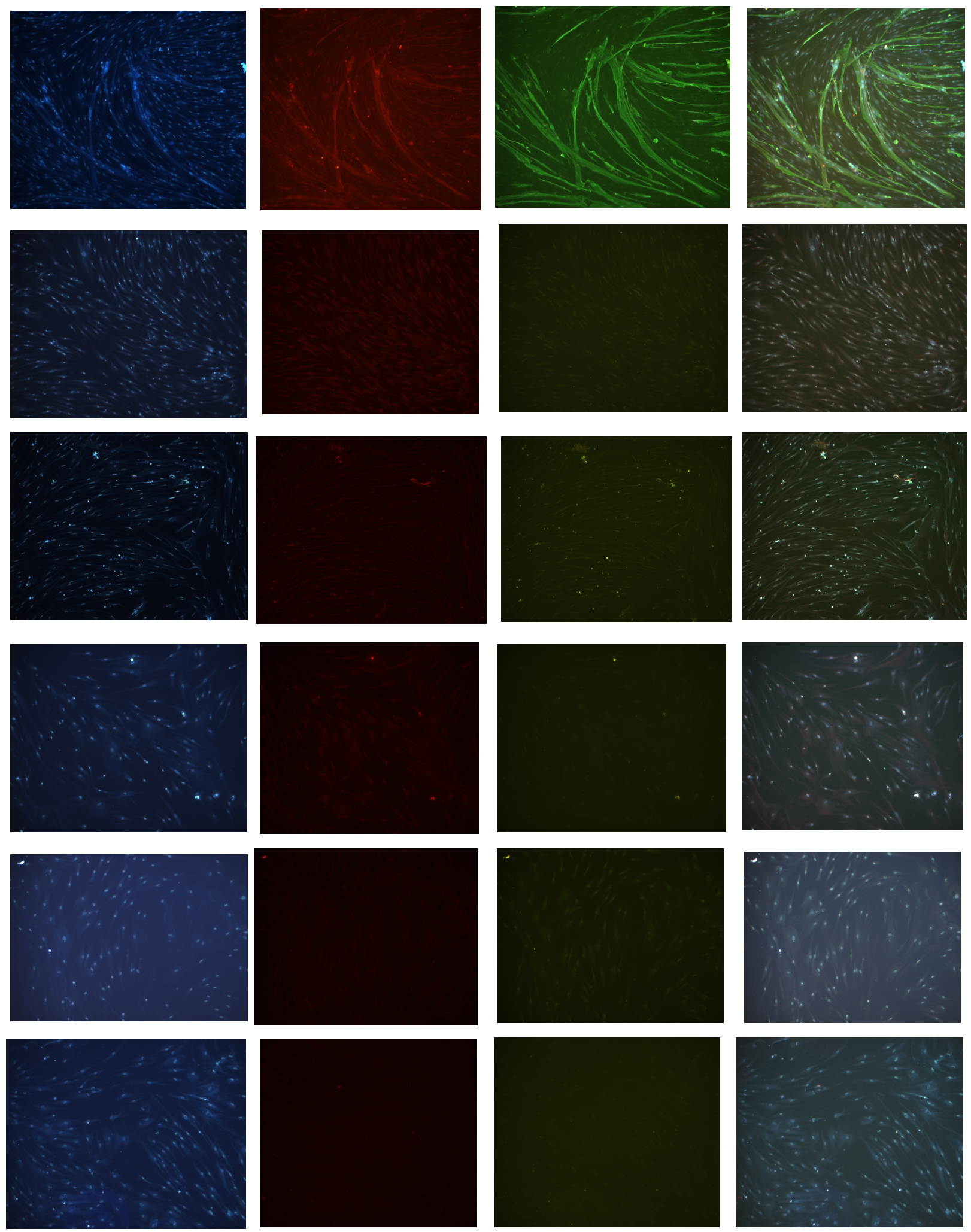

Figura 22: Imagens representativas das diferenciações miogênicas. Linha 1: mioblasto comercial, Linha 2: Fibroblasto, Linha 3: Pericito de Endométrio, Linha 4: Pericito de Trompa, Linha 5: Pericito de tecido adiposo, Linha 6: Pericito de músculo. As colunas representam: Coluna 1: DAPI (marcador nuclear), Coluna 2: Dys1 (Alexa 596), Coluna 3: Miosina de Cadeia Pesada (Alexa 488), Coluna 4: junção das imagens. Aumento de $100 \mathrm{X}$ 
Para os ensaios in vivo fizemos os testes físicos documentados nos materiais e métodos antes e depois do início das injeções. Os dados dos testes físicos estão representados abaixo na figura 23.

\section{Deambulação}

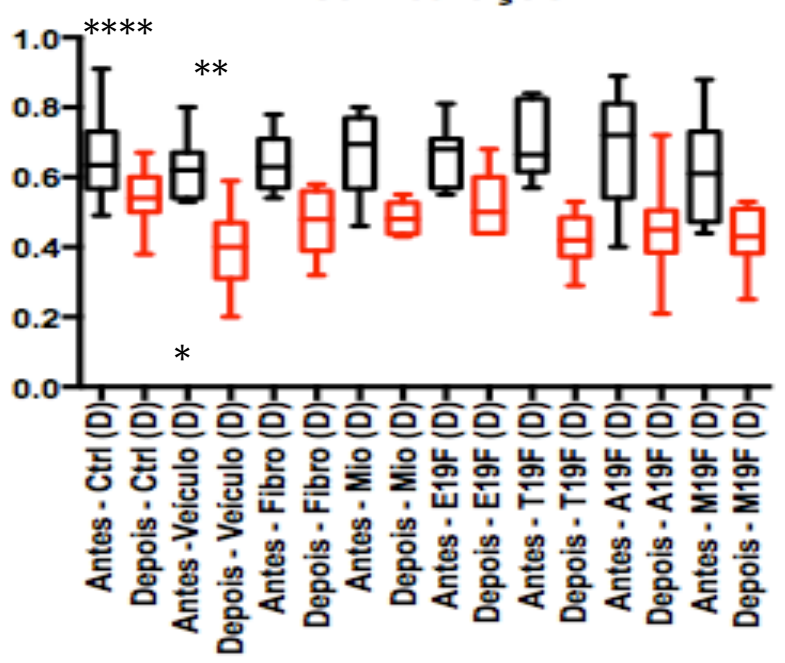

Grip

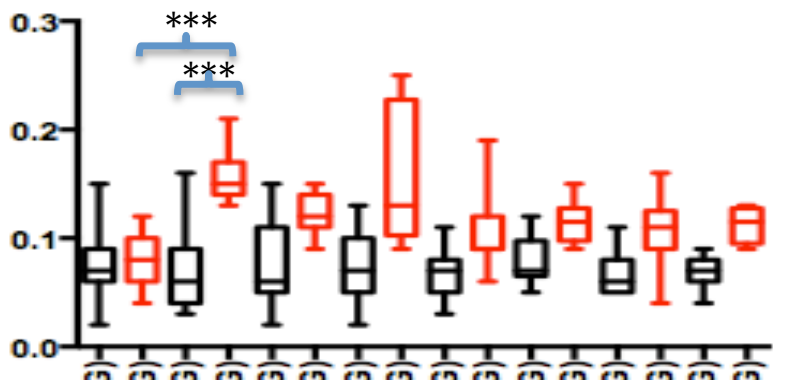

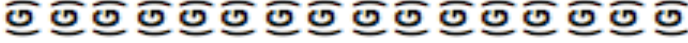

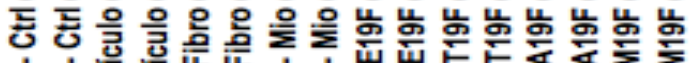

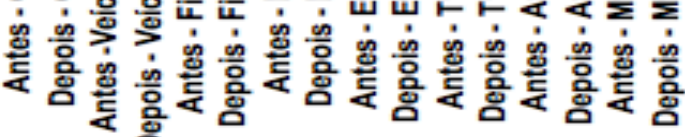

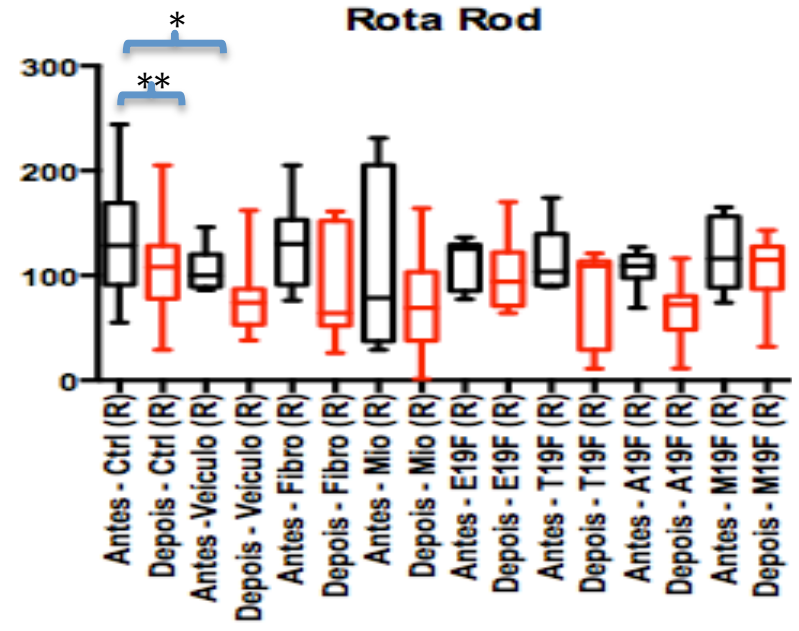

Deambulação

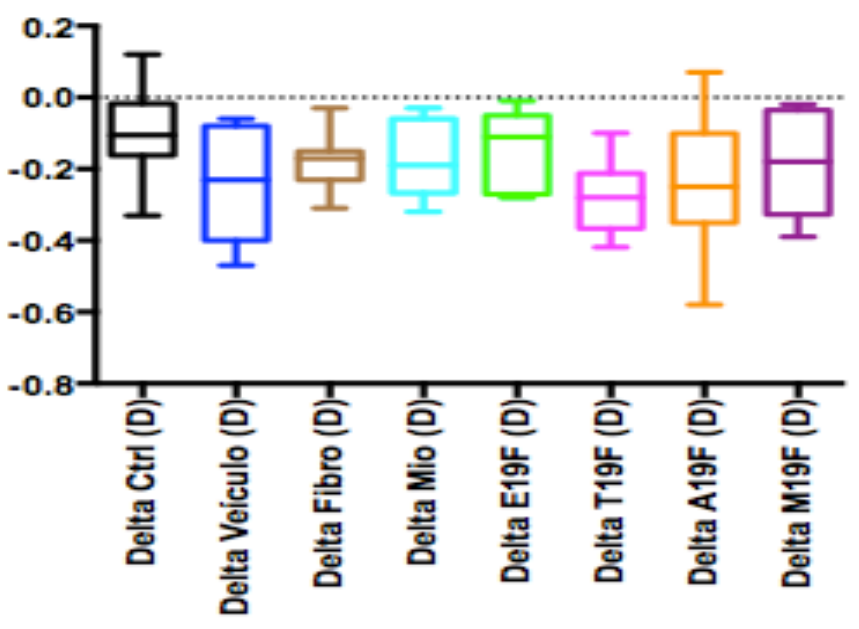

Grip

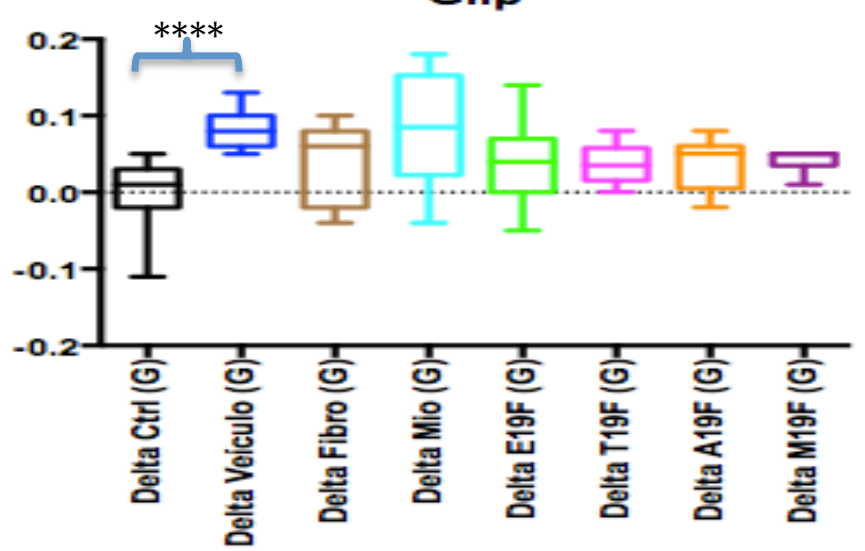

Rota Rod

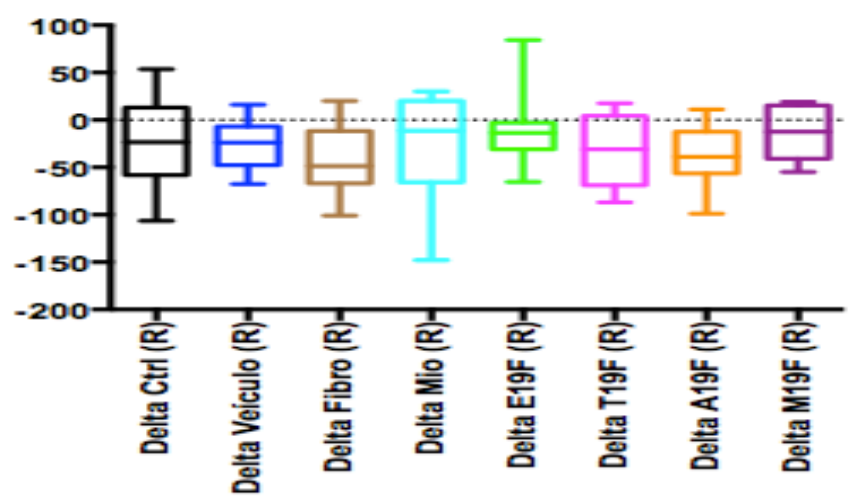


Figura 23: Dados descritivos dos resultados dos testes físicos realizados nos camundongos antes e depois do regime de 2 meses de injeções semanais. Os gráficos da esquerda representam a média dos animais de cada grupo antes (preto) e depois (vermelho). Já os gráficos da direita representam a variação entre antes e depois de cada grupo. Portanto valores de Delta abaixo de 0 indicam piora e o inverso indica melhora. Os valores dos asteriscos são conforme a seguinte anotação:

$<0.0001$

Extremamente Significante

0.0001 to 0.001

Extremamente Significante

0.001 to 0.01

Muito significante

0.01 to 0.05

Significante

Primeiramente vale a pena esclarecer que os animais que chamamos de CTRL (controle) nesses dados são os animais clinicamente saudáveis (selvagens ou heterozigotos quanto a mutação no gene da utrofina) e derivados das mesmas ninhadas que obtivemos os animais afetados (irmãos). Esses animais não receberam injeções com nenhuma substância ou células e o objetivo deles nesse experimento era servir de parâmetro para as nossas análises. Clinicamente, esses animais são claramente distinguíveis dos animais afetados tendo diferenças marcantes na forma de locomoção, curvatura da coluna, e tempo de vida ${ }^{54}$. Os testes físicos visam quantificar se houve diferenças após injeções com célulastronco. Com os resultados dos testes podemos afirmar que:

Deambulação: tanto os animais CTRL $\left({ }^{* * *}\right)$, quanto os animais VEÍCULO $\left({ }^{* *}\right)$ pioraram depois de 2 meses. O resultado do teste depois do tratamento mostrou diferença entre o CTRL e o VEÍCULO, porém não apontou nenhuma diferença entre os grupos de tratamento.

Grip: Os animais CONTROLE não mostraram nenhuma variação ANTES e DEPOIS dos 2 meses. Já os animais VEÍCULO demonstram uma grande diferença entre ANTES e DEPOIS $\left(^{\star * \star}\right.$ ) e também em relação aos CTRLs (evidenciada no DELTA $\left.\operatorname{com}^{\star * \star *}\right)$. 
Rota Rod: Somente os animais CTRL demonstram diferenças entre ANTES e DEPOIS dos 2 meses $\left({ }^{* *}\right)$. Essa diferença também existe entre os dados de ANTES dos animais CTRL e dos dados de ANTES dos animais VEÍCULO (*).

Como mencionado anteriormente, a expectativa de vida dos animais afetados é muito inferior à dos seus irmãos não afetados ${ }^{54}$. Em face a essa diferença, optamos por avaliar a expectativa de vida dos animais tratados. Até a elaboração dessa tese, todos os animais usados no grupo CTRL ainda estavam vivos (exceto 1 caso, tido matematicamente como outlier). O resumo descritivo desses dados segue em alguns gráficos na figura 24 abaixo.

Ao compararmos todas as curvas de tratamento (gráfico à esquerda) entre si notamos uma diferença de sobrevivência entre os animais tratados com pericito de gordura (A19F) e os animais tratados com células que não são pericitos (mioblastos e fibroblastos) $(p=0,005)$, levando em consideração a correção de Bonferroni.
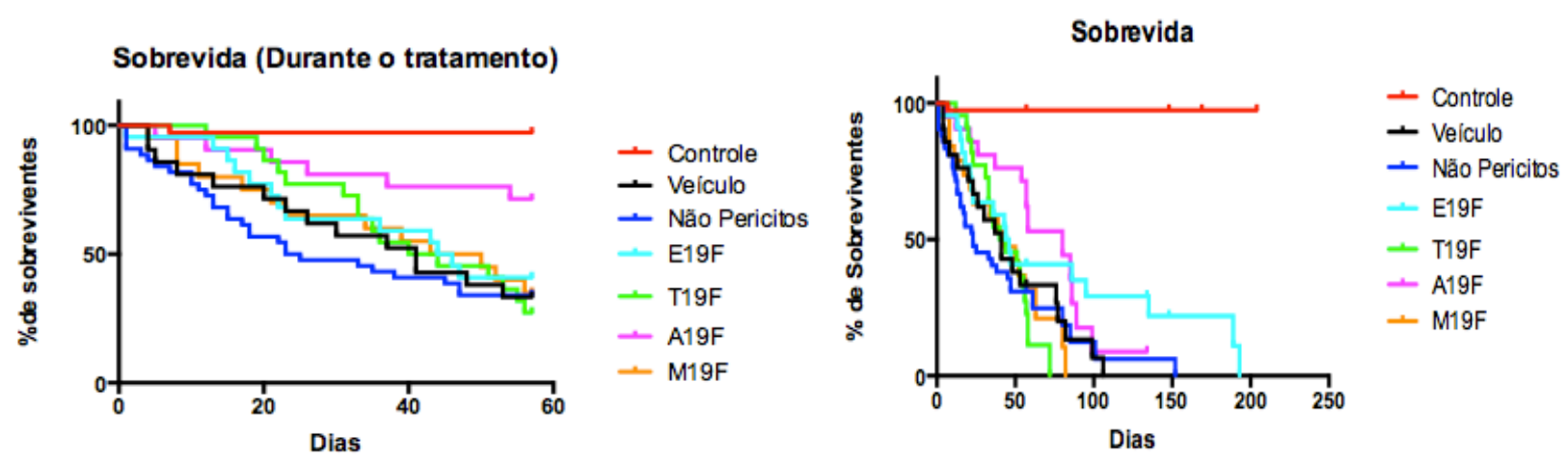

Figura 24: Curva de sobrevivência dos camundongos DKO injetados com populações de pericito de tecidos diferentes da mesma doadora.

Quando analisamos as curvas de sobrevida (gráfico à direita) temos os mesmos resultados que corroboram que as células de pericito de gordura prolongam a vida dos animais em relação a células que não são pericitos. 
Entretanto, na análise dos tecidos desses animais (fígado, baço, rim, músculo e pulmão) nenhum DNA humano foi encontrado (figura 25).

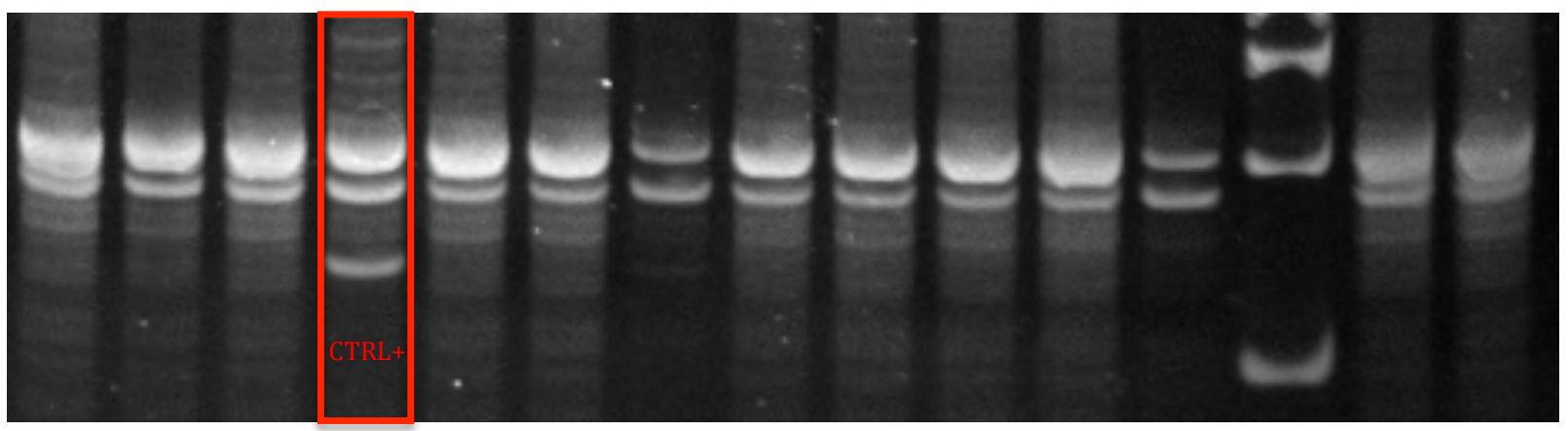

Figura 25: Gel de poliacrilamida de 10\% após o PCR multiplex para identificação de DNA humano nas amostras. Primeira banda: 215pb - Controle + (presente no DNA humano e de camundongo); Segunda banda: 189 pb (somente presente em DNA de camundongo); Terceira banda: 140 pb (somente presente em DNA humano).

\section{VI - Discussão}

A estratégia de separar as células de pericitos dos tecidos antes do cultivo ex vivo é bem embasada na literatura ${ }^{90,80}$ e nos dá um arcabouço fundamental para compararmos se as células derivadas de diferentes fontes possuem o mesmo potencial miogênico. Isso porque, antes de compararmos populações de tecidos diferentes, é importante estarmos certos de que estamos lidando com o mesmo tipo celular. De outra forma, não haveria como obter significado biológico. Nesse estudo utilizamos os mesmo marcadores descritos no experimento de Crisan e colaboradores. No entanto não tivemos uma alta eficiência de separação das populações de pericito de todos os tecidos. De fato, coletamos material de mais de 25 mulheres que passaram por histerectomia total abdominal e somente em um caso (amostra 19) conseguimos isolar as células de todos os tecidos de interesse. Isso pode ser explicado por diversos fatores. Primeiramente, todo o procedimento foi uma implementação inovadora no laboratório, o que sempre traz dificuldades em todos os passos do processo como padronização das etapas de digestão e filtração, 
titulação dos anticorpos, utilização do equipamento (FACS), padronização das condições de isolamento das células e cultivo. Da mesma forma, a quantidade disponível dos materiais era muito pequena, devido a natureza do procedimento cirúrgico. Apesar de sempre termos quantidades suficientes de trompa e endométrio (por ser uma histerectomia total abdominal, o procedimento padrão sempre excisava ambas as estruturas), as quantidades de gordura e de músculo eram muito limitadas atingindo uma média de $10 \mathrm{~g}$ de gordura e de $1 \mathrm{~g}$ de músculo. Como comparação, a equipe de Crisan e colaboradores trabalharam com material fetal (abortado) e lipoaspiração (adulto), o que aumenta substancialmente a quantidade de material para trabalho. Apesar das dificuldades, ainda conseguimos isolar, além das células do indivíduo 19, outras 3 linhagens pareadas de pericitos de gordura, trompa e endométrio (músculo não foi possível em nenhuma das 3).O ritmo de crescimento celular das linhagens foi comparável ao descrito na literatura. No artigo de Crisan as células de pericito tinham uma taxa de crescimento muito próxima da observada em nossas linhagens (figura 25). No entanto, vale a pena ressaltar que observamos um fenômeno diferente em nossas linhagens. O valor encontrado de PDT (do inglês

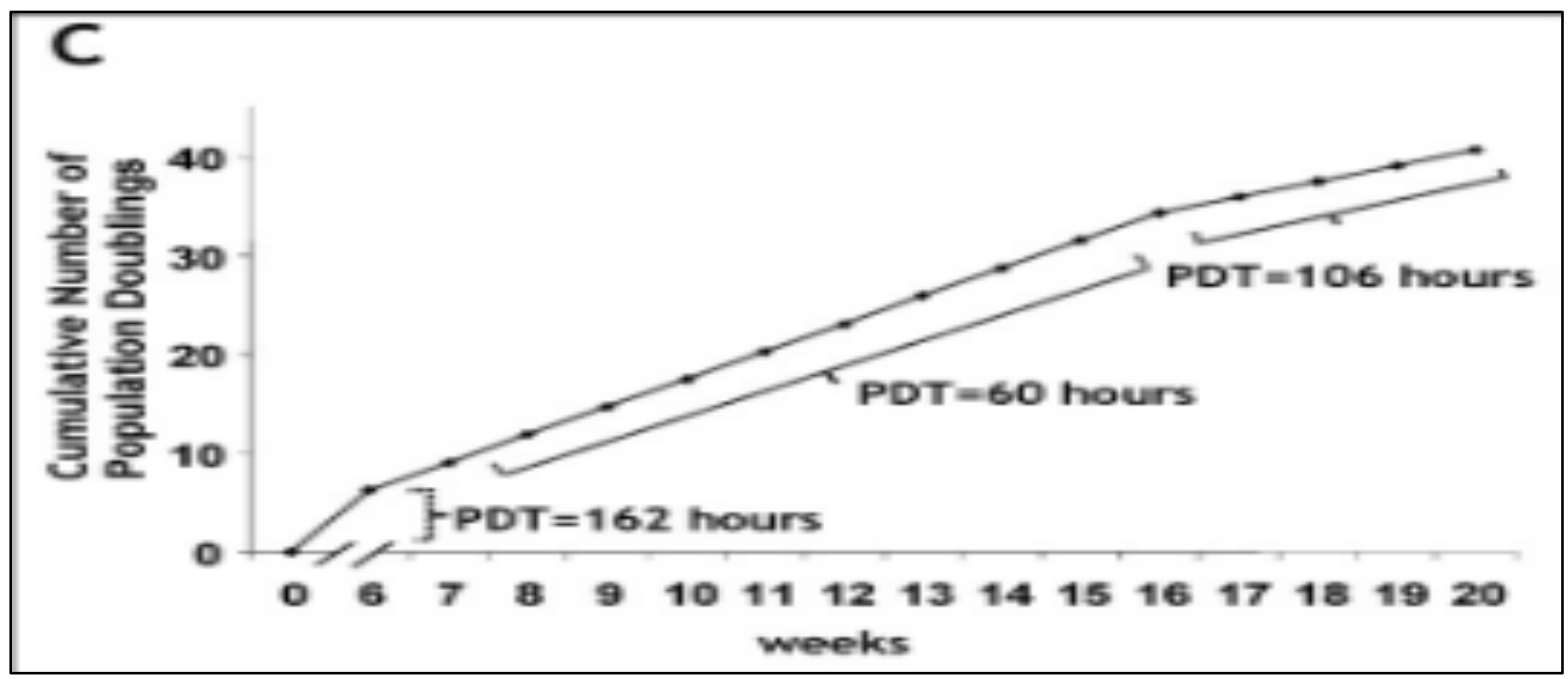

Figura 25: retirado de Crisan, 2008. Figura representativa do crescimento das células de pericito. 
Population Doubling Time) nas nossa linhagens foi medido após a passagem 7, o que seria perto da sétima semana no gráfico da figura 25 . No entanto, anteriormente à esse período observamos um momento de intenso crescimento, o que indicaria uma diminuição do valor do PDT nas semanas anteriores (não considerando o período imediatamente posterior ao plaqueamento) e não de aumento como vemos no gráfico disponibilizado na publicação. A linhagem de pericito de endométrio parece ter uma capacidade proliferativa bem alta (PDT $=33$ horas). Isso pode ser um reflexo da grande vascularização desse órgão. Durante o processo de separação (Figura 26) uma alta porcentagem de células CD146+ foi observada (média de $10 \%$ - no caso da linhagem 19 foi de 6\%), associada ao grande número de células obtidas desse tecido pode ter gerado uma maior quantidade de células viáveis capazes de suportar o crescimento dessa população, diminuindo seu PDT.

\begin{tabular}{|c|c|c|c|}
\hline \multicolumn{4}{|l|}{ Tube: Sorting } \\
\hline Population & \#Events & \%Parent & \%otal \\
\hline All Events & $1,000,000$ & $\# \#$ & 100.0 \\
\hline$\square$ vivas & 671,108 & 67.1 & 67.1 \\
\hline$\square$ pop homog & 655,691 & 97.7 & 65.6 \\
\hline $34-45-$ & 506,570 & 77.3 & 50.7 \\
\hline $34-$ e 45- & 209,153 & 41.3 & 20.9 \\
\hline $146+$ & 63,770 & 12.6 & 6.4 \\
\hline $146+56+$ & 20,757 & 4.1 & 2.1 \\
\hline
\end{tabular}

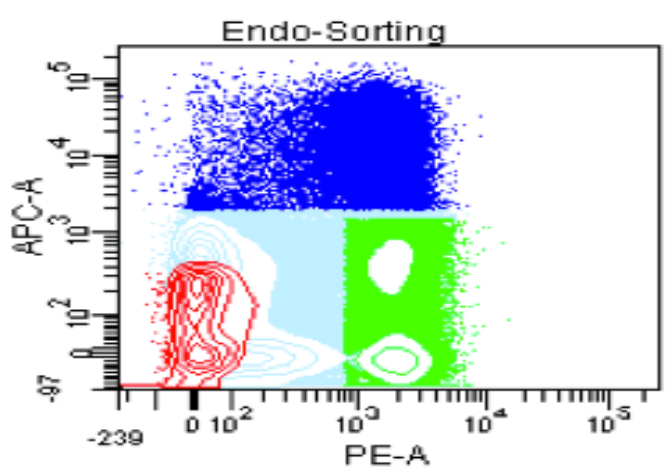

Figura 26: Quantidade de pericitos do tecido endometrial obtidos durante a separação por FACS (população verde).

Ao analisarmos as diferenciações miogênicas dessas linhagens devemos sempre estar atentos aos mais diversos aspectos do processo. A análise de técnicas in vitro para a representação de processos biológicos já é deficiente devido a complexidades inerente a qualquer sistema in vivo. Minimizar essas análises ainda mais apoiando-se na expressão de um só marcador, ou uma única técnica, somente diminui as chances de reprodutibilidade experimental. 
$A$ diferenciação miogênica é um processo complexo e que envolve muitos aspectos da biologia celular. Nesse sentido, as linhagens utilizadas nessa tese foram submetidas ao protocolo mais aceito e publicado na literatura (diminuição de soro) juntamente com as técnicas mais comumente aceitas de análise (PCR em tempo real, western blot e IF) além de análise morfológica (formação de miotúbulos). Em nenhum momento, as células desse estudo apresentaram qualquer sinal de comprometimento com a diferenciação miogênica. Diferentemente dos mioblastos comerciais (Life Technologies) e dos mioblastos (CD56+) separados por FACS. Nenhuma das linhagens de pericito mostrou fusão em cultura durante os 15 dias de protocolo de diferenciação. As células de fibroblasto de pele apresentavam uma morfologia muito similar aos pericitos quando submetidas ao mesmo meio de diferenciação (figura 21). Quando analisadas, as expressões gênicas (por western blot, PCR em tempo real e IF) confirmavam a expressão insuficiente dos marcadores clássicos de diferenciação miogênica (Myod, Myf5 e Miosina de cadeia pesada).

Esses resultados vão contra o que observamos na literatura ${ }^{90,109}$. De fato, ambos os grupos que avaliaram células de pericito e sua capacidade de diferenciação muscular comprovaram a mesma não somente in vitro mas também in vivo ${ }^{80,148}$. No entanto, é digno de nota algumas diferenças. No trabalho de Dellavalle e colaboradores, a população de pericitos que foi separada diretamente do tecido (que no caso era somente músculo) tinha o seguinte perfil de marcação; CD34-CD45-CD56-ALP+. As células eram fosfatase alcalina (ALP) positivas e não CD146+ como no nosso estudo. O meio de cultivo usado nesta publicação também é outro, apesar de ser um meio que também suporta crescimento de células 
endoteliais. Já no trabalho de Crisan, todos os experimentos de diferenciação miogênica foram feitos imediatamente após a separação das células (período de apenas 10 dias em meio de crescimento). Em nosso experimento, cultivamos as células em meio EBM-2 (Lonza) até a primeira passagem e depois cultivamos com meio DMEM-F12, mais simples e sem fatores, até a passagem 4 quando as células foram congeladas. Após essa passagem, todas as células foram cultivadas com 0 meio EMB-2. Não podemos ignorar este fato, pois é amplamente reconhecido na literatura que meio de cultivo de células ex vivo influenciam significativamente diversas propriedades de uma população celular como taxa de crescimento e potencial de diferenciação ${ }^{4,149,150,151}$. Portanto, é possível que nossa forma de cultivo tenha comprometido o potencial dessas células.

Recentemente, um estudo feito em camundongos demonstrou que existem subpopulações de pericito dentro do músculo (e provavelmente dentro de outros tecidos também). As populações podem ser dividas em pericitos do tipo-1 e pericitos do tipo-2 de acordo com seus marcadores. No caso de camundongos os marcadores envolvidos eram NG2 e Nestina. Os pericitos do tipo-1 (Nestina-/NG2+) são exclusivamente adipogênicos enquanto os pericitos do tipo-2 (Nestina-/NG2-) são exclusivamente miogênicos. Assim como no experimento de Crisan e colaboradores, Birbrair et al cultivaram pouco as células antes de verificar o potencial (3 dias no máximo) ${ }^{152}$. Não sabemos, no caso de humanos, quais são os marcadores para essa duas subpopulações de pericitos ou se de fato existem. No entanto, podemos hipotetizar que em nossas linhagens pode ter havido um favorecimento de outras linhagens que não as miogênicas nas quais estávamos interessados. 
$\mathrm{Na}$ análise do experimento in vivo obtivemos alguns resultados que merecem uma discussão aprofundada. Primeiramente, discutiremos os testes físicos individualmente.

\section{Deambulação}

A) os animais CONTROLE pioram com o tempo. Ou seja, o envelhecimento natural já causa uma diferença de performance no teste. Pudemos perceber que essa diferença também foi percebida em animais afetados tratados com VEÍCULO.

B) Se compararmos os dois estados de início (CONTROLE vs VEÍCULO) o teste não consegue discernir a diferença entre os animais. Porém ao final dos 2 meses, a diferença entre CONTROLE vs Veículo já era significativa para ser avaliada por este teste. Portanto, este teste é adequado para avaliar os animais pós tratamento para verificar se houve alguma melhora.

C) Submetemos os dados dos grupos tratados com os 6 tipos de células e o veículo a um teste ANOVA de múltiplas variáveis que não indicou nenhuma diferença entre os grupos avaliados

\section{Grip}

A) O teste não detectou nenhuma variação na força das patas anteriores dos animais CONTROLE depois de 2 meses. Já os animais VEÍCULO demonstraram uma grande diferença entre antes e depois dos dois meses. Surpreendentemente a mudança foi positiva, ou seja, os animais, de acordo com este teste, melhoraram espontaneamente. 
B) Não só houve uma melhora significativa, como os valores DEPOIS dos 2 meses eram significativamente maiores do que os dos animais CONTROLES (evidenciado pelo DELTA)

C) Esse resultado nos levou a desconsiderar o teste, já que claramente este não estava indicando nenhum parâmetro compreensível na situação clínica do animal.

\section{Rota Rod}

A) Os animais CONTROLES pioraram depois de 2 meses. Quando comparado aos animais VEÍCULO, os animais CONTROLE somente mostram alguma diferença nos dados coletados ANTES do período do tratamento.

B) Como não seria possível distinguir nenhuma melhora física entre os tratamentos (uma vez que que não conseguimos distinguir o animal CONTROLE do VEÍCULO no período DEPOIS), não usamos os dados deste teste para avaliação dos animais.

Ao analisarmos a curva de sobrevivência, podemos chegar a algumas conclusões importantes e interessantes. Da mesma forma que fizemos com os testes físicos, primeiro analisamos se as curvas de sobrevivência entre animais CONTROLES e VEÍCULO poderiam ser consideradas matematicamente como distintas e, por dois diferentes testes (Log-rank e Gehan-Breslow-Wilcoxon), concluímos que sim $(\mathrm{p}<0,0001)$. 
Ao compararmos todas as curvas entre si (sem incluir o grupo CONTROLE, dessa vez) alcançamos o mesmo resultado $(p<0,0001)$. Passamos portanto a procurar quais curvas seriam diferentes. Observamos que os animais injetados com as células de pericito de tecido adiposo são as únicas que apresentam alguma diferença estatística entre VEÍCULO e entre animais injetados com células que não são pericitos (mioblastos e fibroblastos). Nenhuma das outras linhagens mostrou essa diferença. Apesar das evidências em relação ao grupo NÃO PERICITO serem mais fortes do que ao VEÍCULO (valor do $\mathrm{p}$ foi menor para o grupo NÃO PERICITO), não houve diferença entre os grupos VEÍCULO e NÃO PERICITO. Sendo assim temos uma primeira evidência importante apontando que as células de pericitos de diferentes fontes de uma mesma pessoa não são equivalentes. Em um regime de injeções intraperitoneais, pudemos notar diferenças relevantes na sobrevida dos animais tratados com pericitos derivados de tecido adiposo em relação à todos os outros (músculo, trompa e endométrio).

Apesar disso, na análise dos tecidos desses animais, não detectamos material genético humano que daria indícios de migração para algum tecido. Vale, no entanto, ressaltar que a nossa reação de PCR tem sensibilidade limitada. Isto é, no teste que realizamos conseguimos encontrar até $0,5 \%$ de DNA humano em mistura com DNA de camundongo num total de $10 \mathrm{ng}$ de DNA. Isso significa que poderíamos identificar $5 \mathrm{pg}$ de DNA humano em uma reação. Sabendo que em média conseguimos extrair 10 ug de DNA de um tecido qualquer, seria necessário que houvesse nesse total $50 \mathrm{ng}$ de DNA humano, (o que representa aproximadamente 7575 células humanas ${ }^{146}$ ) para que pudéssemos identificar algum resultado. Logo, qualquer quantidade de células menor do que 7575 que tenha 
atingido esses tecidos passaria desapercebido em nossos testes. No total, foram injetadas 8 milhões de células no decorrer de 8 semanas.

Por outro lado, a diferença observada no grupo injetado com células de pericito de gordura poderia ser explicada por algum efeito parácrino ${ }^{111}$ inerente às células ou até mesmo incitado pós injeção das células. Para responder à essas perguntas, estamos avaliando, por microarray (Affymetrix) a expressão dessas células em solução salina e condicionada com lavado de peritônio dos animais afetados. Também estamos investigando algumas citocinas que essas células liberam diante deste meio condicionado para verificarmos se o efeito dessas células está relacionado ao efeito imunomodulatório já descrito para este tipo celular ${ }^{119,153}$.

Entretanto, podemos concluir que as células de pericito de diferentes órgãos de uma mesma pessoa não possuem as mesmas propriedades e os pericitos de gordura parecem exercer uma função benéfica de aumento de expectativa de vida de animais duplo mutante para distrofina e utrofina sem evidenciarem uma melhora clínica perceptível nos testes físicos utilizados. 


\section{Capítulo 5}

\section{I - Discussão geral}

No decurso dessa tese tivemos como primeiro objetivo avaliar o potencial miogênico de diferentes tipos de CTMs. No entanto, este assunto, como tantos outros na ciência, passou por profundas transformações ao longo do tempo que nos obrigou a reformularmos nossas hipóteses, conceitos e abordagens experimentais. Como deixamos claro em nossa introdução, acreditamos que o conceito difundido de CTMs, inclusive no meio científico, está muito confuso e evidências científicas sólidas são necessárias para pavimentar o caminho do conhecimento. Especialmente em uma busca por uma terapia celular, os dados precisam ser fortes o suficiente para iniciarmos especulações sobre alguma terapia em humanos.

As células que incialmente escolhemos para comparação do potencial miogênico eram células de cordão umbilical (UCMSC), de endométrio (ERC) e de músculo da face (FMDSC). Tentamos validar a diferenciação miogênica dessas células por diversos protocolos descritos na literatura porém sem resultados positivos. A nossa falta de sucesso se corroborava quando incluímos em nossas análises controles positivos (mioblastos), ou seja, células que passavam naturalmente pelo processo de diferenciação miogênica e que, portanto, representam o padrão ouro de comparação. Também incluímos os controles negativos, células que normalmente não respondiam ao processo de diferenciação 
(fibroblastos). Vale a pena ressaltar que fusão de 2 células é um processo comum em culturas ex vivo, e portanto é necessária a verificação de um controle negativo (como fibroblasto por exemplo) para garantir que o resultado não é um artefato de cultivo celular. Fomos críticos em todos os experimentos ao avaliar as mudanças morfológicas esperadas por uma diferenciação miogênica. Como citado em diversas publicações de alto impacto ${ }^{154,155,156,157,24,142,158,141}$ a diferenciação miogênica deve ser seguida de fusão e formação de miotúbulos. Porém percebemos que nem sempre esse parâmetro é levado em consideração, surgindo assim incongruências. Acreditamos que o cumprimento dessas exigências nos permite gerar resultados que realmente poderão ser confiáveis.

Nesse estudo não nos limitamos às mudanças morfológicas, mas também nos envolvemos em técnicas de biologia molecular para verificar o real potencial miogênico das células. É de importância também ressaltarmos que nos preocupamos em sempre normalizar os dados de expressão (PCR em tempo real) das diferenciações das células de interesse pelo controle positivo. Isso porque percebemos que a normalização feita pelo tempo 0 de cada diferenciação individual (situação encontrada em algumas publicações) nos dá a falsa impressão de diferenciação celular por indicar, muitas vezes, aumento de expressão de certos genes. No entanto, a quantidade de produto sendo realmente expresso no contexto da população total é insuficiente para desencadear um processo de mudança funcional da célula.

No caso de imunofluorescência e Western Blot é necessária a validação dos anticorpos de interesse. Nos experimentos realizados nesse estudos conseguimos padronizar alguns anticorpos de diferenciação miogênica terminal (Miosina de 
cadeia Pesada e Distrofina), porém não tivemos sucesso com os anticorpos contra os fatores de transcrição comumente expressos no início da diferenciação miogênica (Myf 5 e Myod). Com relação ao PCR em tempo real, utilizamos 6 genes de interesse (Myf5, Myod, Mrf4, Myogenina, Distrofina e Miosina de Cadeia pesada) e 2 endógenos (gapdh e beta actina)

Observarmos que os meios de cultivo utilizados para as CTMs, no geral, são meios simplificados sem fatores de crescimento e com trocas entre 3 a 4 dias. Já as células de pericito são cultivadas com meios enriquecidos de fatores (como FGF, VEGF, IGF etc) bem definidos e trocas a cada dois dias o que poderia manter essas células em melhores condições e potencial.

Não fizemos, todavia, nesse estudo uma avaliação in vivo do potencial miogênico dessas populações. Essa avaliação é de grande valia pois nos indica com maior confiança se o potencial observado in vitro - ou a falta dele - também acontece in vivo. Na literatura, observamos que os testes in vivo se dão a partir de uma injeção local de cardiotoxina, que induz necrose muscular. Depois de 2-3 dias, injeta-se localmente as células em que se tem interesse em testar a capacidade miogênica. Depois de 14-21 dias retira-se o músculo injetado, faz-se cortes histológicos e imunofluorescência para marcadores de diferenciação miogênica. É digno de nota que em casos nos quais os transplantes de células envolvem espécies diferentes (humanos em camundongos, como é o nosso caso) precisamos utilizar animais imunodeficientes para garantir que a resposta não seja perturbada por um efeito de imunorejeição. Sendo assim, é recomendado o uso de animais SCID ou $\mathrm{Rag}^{-/-} / \mathrm{MDX}^{159}$ e o uso de anticorpos específicos contra proteínas humanas para confirmação da contribuição proteica exógena nas fibras analisadas. Estamos 
envolvidos na busca de colaborações para a padronizações dessa técnica para podermos responder de forma mais categórica às perguntas sobre potencial miogênico in vivo das linhagens de interesse.

Ao analisarmos cautelosamente os dados dos experimentos in vivo percebemos que a abordagem usada foi simplista (injeções intraperitoneais) e as medições, diretas (expectativa de vida). Todavia, não podemos deixar de considerar outras possibilidades de tratamento. Não sabemos ainda se injeções intraperitoneais são as mais eficazes para esse tipo de proposta. Pudemos perceber que o efeito nos animais tratados é independente da presença das células no tecido que sofre a degeneração (músculo), já que não foram observadas células em nenhum tecido investigado. Atualmente estamos investigando a mudança transcricional dessas células em meio condicionado de peritônio para entender as diferenças que podem estar associadas aos resultados. É digno de nota lembrar que não encontramos diferenças em nenhum aspecto funcional dos animais (testes físicos) e portanto não temos base para afirmarmos qualquer tipo de melhora clínica desses animais. Mas não podemos desconsiderar a possiblidade de injeções intravenosas ou até mesmo arteriais pudessem ser mais eficientes no processo estudado.

Em um estudo realizado com camundongos progeróides ${ }^{160}$ (modelo de envelhecimento precoce), MDSC (do inglês Muscle Derived Stem Cells) de camundongos selvagens e jovens foram injetadas intraperitonialmente e mostraram um aumento da expectativa de vida nesse modelo. De forma semelhante ao nosso estudo, não foram encontradas células em quantidades satisfatórias para justificar a melhora dos animais através de um potencial regenerativo. Apesar disso foi 
percebida uma maior vascularização da musculatura e aumento da área de seção do músculo. Isso reforça, portanto, nossos resultados e nos abre algumas perspectivas da forma de atuação dessas células.

Outro aspecto desse estudo é a nossa limitação quanto à sensibilidade de identificação de material humano em DNA extraído de tecidos de camundongos. Estamos aperfeiçoando nossas técnicas para que aumentemos a sensibilidade desses procedimentos e assim consigamos perceber a real contribuição dessas células nos tecidos estudados. 


\section{II - Conclusões}

Concluímos portanto:

1- As CTMs inicialmente estudadas (UCMSC, ERC e FMDSC) não possuem um potencial miogênico (in vitro) considerável para serem utilizadas em abordagens terapêuticas para doenças musculares com intuito regenerativo;

2- As células derivadas de pericito (CD34-CD45-CD56CD146+) não apresentaram potencial miogênico nas condições desse estudo (in vitro):

3- Células de pericito de diferentes tecidos da mesma pessoa não são equivalentes:

4- $\quad$ Células de pericito de tecido adiposo humano injetadas intraperitonialmente, semanalmente, por 2 meses, em camundongos DKO (MDX/Utrofina) provocam um aumento significativo: na expectativa de vida. 


\section{Bibliografia}

1 Caplan, A. Why are MSCs therapeutic? New data: new insight. The Journal of pathology 217, 318-324, doi:10.1002/path.2469 (2009).

2 English, K. \& Mahon, B. Allogeneic mesenchymal stem cells: agents of immune modulation. Journal of cellular biochemistry 112, 1963-1968, doi:10.1002/jcb.23119 (2011).

3 Cossu, G. \& Bianco, P. Mesoangioblasts--vascular progenitors for extravascular mesodermal tissues. Current opinion in genetics \& development 13, 537-542, doi:10.1016/j.gde.2003.08.001 (2003).

4 Schugar, R. et al. High harvest yield, high expansion, and phenotype stability of CD146 mesenchymal stromal cells from whole primitive human umbilical cord tissue. Journal of biomedicine \& biotechnology 2009, 789526, doi:10.1155/2009/789526 (2009).

5 Godin, I. \& Cumano, A. The hare and the tortoise: an embryonic haematopoietic race. Nature reviews. Immunology 2, 593-604, doi:10.1038/nri857 (2002).

6 Emery, A. Muscular dystrophy into the new millennium. Neuromuscular disorders : NMD 12, 343-349, doi:10.1016/S0960-8966(01)00303-0 (2002).

$7 \quad$ Mercuri, E. \& Muntoni, F. Muscular dystrophies. Lancet, doi:10.1016/S01406736(12)61897-2 (2013). 
8 Gumerson, J. \& Michele, D. The dystrophin-glycoprotein complex in the prevention of muscle damage. Journal of biomedicine \& biotechnology 2011, 210797, doi:10.1155/2011/210797 (2011).

9 Le Rumeur, E., Winder, S. \& Hubert, J.-F. Dystrophin: more than just the sum of its parts. Biochimica et biophysica acta 1804, 1713-1722, doi:10.1016/j.bbapap.2010.05.001 (2010).

10 Ramachandran, J. et al. Nitric oxide signalling pathway in Duchenne muscular dystrophy mice: up-regulation of L-arginine transporters. The Biochemical journal 449, 133-142, doi:10.1042/BJ20120787 (2013).

11 Kharraz, Y., Guerra, J., Mann, C., Serrano, A. \& Muñoz-Cánoves, P. Macrophage plasticity and the role of inflammation in skeletal muscle repair. Mediators of inflammation 2013, 491497, doi:10.1155/2013/491497 (2013).

12 Ervasti, J. Dystrophin, its interactions with other proteins, and implications for muscular dystrophy. Biochimica et biophysica acta 1772, 108-117, doi:10.1016/j.bbadis.2006.05.010 (2007).

13 Emery, A. The muscular dystrophies. The Lancet (2002).

14 Ahn, A. \& Kunkel, L. The structural and functional diversity of dystrophin. Nature genetics 3, 283-291, doi:10.1038/ng0493-283 (1993).

15 Koenig, M. et al. The molecular basis for Duchenne versus Becker muscular dystrophy: correlation of severity with type of deletion. American journal of human genetics 45, 498-506 (1989). 
16 Hoffman, E., Brown, R. \& Kunkel, L. Dystrophin: the protein product of the Duchenne muscular dystrophy locus. Cell 51, 919-928, doi:10.1016/00928674(87)90579-4 (1987).

17 Petrof, B., Shrager, J., Stedman, H., Kelly, A. \& Sweeney, H. Dystrophin protects the sarcolemma from stresses developed during muscle contraction. Proceedings of the National Academy of Sciences of the United States of America 90, 3710-3714, doi:10.1073/pnas.90.8.3710 (1993).

18 Gros, J., Manceau, M., Thomé, V. \& Marcelle, C. A common somitic origin for embryonic muscle progenitors and satellite cells. Nature 435, 954-958, doi:10.1038/nature03572 (2005).

19 Mauro, A. Satellite cell of skeletal muscle fibers. The Journal of biophysical and biochemical cytology (1961).

20 Lepper, C., Partridge, T. \& Fan, C.-M. An absolute requirement for Pax7-positive satellite cells in acute injury-induced skeletal muscle regeneration. Development (Cambridge, England) 138, 3639-3646, doi:10.1242/dev.067595 (2011).

21 Yin, H., Price, F. \& Rudnicki, M. Satellite cells and the muscle stem cell niche. Physiological reviews 93, 23-67, doi:10.1152/physrev.00043.2011 (2013).

22 Bischoff, R. A satellite cell mitogen from crushed adult muscle. Developmental biology 115, 140-147, doi:10.1016/0012-1606(86)90235-6 (1986).

23 Collins, C. et al. Stem cell function, self-renewal, and behavioral heterogeneity of cells from the adult muscle satellite cell niche. Cell 122, 289-301, doi:10.1016/j.cell.2005.05.010 (2005). 
24 Sacco, A., Doyonnas, R., Kraft, P., Vitorovic, S. \& Blau, H. Self-renewal and expansion of single transplanted muscle stem cells. Nature 456, 502-506, doi:10.1038/nature07384 (2008).

25 Laterza, 0. et al. Plasma MicroRNAs as sensitive and specific biomarkers of tissue injury. Clinical chemistry 55, 1977-1983, doi:10.1373/clinchem.2009.131797 (2009).

26 Sonnet, C. et al. Human macrophages rescue myoblasts and myotubes from apoptosis through a set of adhesion molecular systems. Journal of cell science 119, 2497-2507, doi:10.1242/jcs.02988 (2006).

27 Paul, P. The effects of colchicine on regeneration of mouse skeletal muscle. The Anatomical Record 139, doi:10.1002/ar.1091390208 (1961).

28 Quinlan, J. et al. Radiation inhibition of mdx mouse muscle regeneration: dose and age factors. Muscle \& nerve 18, 201-206, doi:10.1002/mus.880180209 (1995).

29 Campion, D. The muscle satellite cell: a review. International review of cytology 87, 225-251 (1984).

30 Blaveri, K. et al. Patterns of repair of dystrophic mouse muscle: studies on isolated fibers. Developmental dynamics : an official publication of the American Association of Anatomists 216, 244-256, doi:10.1002/(SICI)10970177(199911)216:3<244::AID-DVDY3>3.0.C0;2-9 (1999). 
31 Blaivas, M. \& Carlson, B. Muscle fiber branching--difference between grafts in old and young rats. Mechanisms of ageing and development 60, 43-53, doi:10.1016/0047-6374(91)90108-C (1991).

32 Jockusch, H. \& Voigt, S. Migration of adult myogenic precursor cells as revealed by GFP/nLacZ labelling of mouse transplantation chimeras. Journal of cell science 116, 1611-1616, doi:10.1242/jcs.00364 (2003).

33 Webster, C. \& Blau, H. Accelerated age-related decline in replicative life-span of Duchenne muscular dystrophy myoblasts: implications for cell and gene therapy. Somatic cell and molecular genetics 16, 557-565, doi:10.1007/BF01233096 (1990).

34 Alfaro, L. et al. CD34 promotes satellite cell motility and entry into proliferation to facilitate efficient skeletal muscle regeneration. Stem cells (Dayton, Ohio) 29, 2030-2041, doi:10.1002/stem.759 (2011).

35 Pisani, D. et al. Hierarchization of myogenic and adipogenic progenitors within human skeletal muscle. Stem cells (Dayton, Ohio) 28, 2182-2194, doi:10.1002/stem.537 (2010).

36 Cao, Y. et al. Global and gene-specific analyses show distinct roles for Myod and Myog at a common set of promoters. The EMBO journal 25, 502-511, doi:10.1038/sj.emboj.7600958 (2006).

37 Gussoni, E. et al. Dystrophin expression in the mdx mouse restored by stem cell transplantation. Nature 401, 390-394, doi:10.1038/43919 (1999). 
38 Mitchell, K. et al. Identification and characterization of a non-satellite cell muscle resident progenitor during postnatal development. Nature cell biology 12, 257266, doi:10.1038/ncb2025 (2010).

39 Qu-Petersen, Z. et al. Identification of a novel population of muscle stem cells in mice: potential for muscle regeneration. The Journal of cell biology 157, 851-864, doi:10.1083/jcb.200108150 (2002).

40 Joe, A. et al. Muscle injury activates resident fibro/adipogenic progenitors that facilitate myogenesis. Nature cell biology 12,153-163, doi:10.1038/ncb2015 (2010).

41 Murphy, M., Lawson, J., Mathew, S., Hutcheson, D. \& Kardon, G. Satellite cells, connective tissue fibroblasts and their interactions are crucial for muscle regeneration. Development (Cambridge, England) 138, 3625-3637, doi:10.1242/dev.064162 (2011).

42 Koenig, M. et al. Complete cloning of the Duchenne muscular dystrophy (DMD) cDNA and preliminary genomic organization of the DMD gene in normal and affected individuals. Cell 50, 509-517, doi:10.1016/0092-8674(87)90504-6 (1987).

43 Gieseler, K., Grisoni, K. \& Ségalat, L. Genetic suppression of phenotypes arising from mutations in dystrophin-related genes in Caenorhabditis elegans. Current biology : CB 10, 1092-1097, doi:10.1016/S0960-9822(00)00691-6 (2000).

44 Guyon, J. et al. Modeling human muscle disease in zebrafish. Biochimica et biophysica acta 1772, 205-215, doi:10.1016/j.bbadis.2006.07.003 (2007). 
45 Winand, N., Edwards, M., Pradhan, D., Berian, C. \& Cooper, B. Deletion of the dystrophin muscle promoter in feline muscular dystrophy. Neuromuscular disorders : NMD 4, 433-445, doi:10.1016/0960-8966(94)90082-5 (1994).

46 Bulfield, G., Siller, W., Wight, P. \& Moore, K. X chromosome-linked muscular dystrophy (mdx) in the mouse. Proceedings of the National Academy of Sciences of the United States of America 81, 1189-1192, doi:10.1073/pnas.81.4.1189 (1984).

47 Cooper, B. et al. The homologue of the Duchenne locus is defective in X-linked muscular dystrophy of dogs. Nature 334, 154-156, doi:10.1038/334154a0 (1988).

48 Kawahara, G. \& Kunkel, L. Zebrafish based small molecule screens for novel DMD drugs. Drug discovery today. Technologies 10, doi:10.1016/j.ddtec.2012.03.001 (2013).

49 Im, W. et al. Differential expression of dystrophin isoforms in strains of mdx mice with different mutations. Human molecular genetics 5, 1149-1153, doi:10.1093/hmg/5.8.1149 (1996).

50 Sacco, A. et al. Short telomeres and stem cell exhaustion model Duchenne muscular dystrophy in mdx/mTR mice. Cell 143, 1059-1071, doi:10.1016/j.cell.2010.11.039 (2010).

51 Guy, S. B., Louise, V. B. N., Carol, Y., Elizabeth, O. \& Clarke, R. S. Different distributions of dystrophin and related proteins at nerve-muscle junctions. NeuroReport 3, doi:10.1097/00001756-199210000-00009 (1992). 
52 Law, D., Allen, D. \& Tidball, J. Talin, vinculin and DRP (utrophin) concentrations are increased at mdx myotendinous junctions following onset of necrosis. Journal of cell science 107 ( Pt 6), 1477-1483 (1994).

53 Winder, S. The membrane-cytoskeleton interface: the role of dystrophin and utrophin. Journal of muscle research and cell motility 18, 617-629, doi:10.1023/A:1018627705273 (1997).

54 Deconinck, A. et al. Utrophin-dystrophin-deficient mice as a model for Duchenne muscular dystrophy. Cell 90, 717-727, doi:10.1016/S0092-8674(00)80532-2 (1997).

55 Sharp, N. et al. An error in dystrophin mRNA processing in golden retriever muscular dystrophy, an animal homologue of Duchenne muscular dystrophy. Genomics 13, 115-121, doi:10.1016/0888-7543(92)90210-J (1992).

56 Partridge, T. The mdx mouse model as a surrogate for Duchenne muscular dystrophy. The FEBS journal, doi:10.1111/febs.12267 (2013).

57 Drachman, D., Toyka, K. \& Myer, E. Prednisone in Duchenne muscular dystrophy. Lancet 2, 1409-1412, doi:10.1016/S0140-6736(74)90071-3 (1974).

58 Hoffman, E. et al. Novel approaches to corticosteroid treatment in Duchenne muscular dystrophy. Physical medicine and rehabilitation clinics of North America 23, 821-828, doi:10.1016/j.pmr.2012.08.003 (2012).

59 Mendell, J. et al. Randomized, double-blind six-month trial of prednisone in Duchenne's muscular dystrophy. The New England journal of medicine 320, 1592-1597, doi:10.1056/NEJM198906153202405 (1989). 
60 Kinali, M., Mercuri, E., Main, M., Muntoni, F. \& Dubowitz, V. An effective, lowdosage, intermittent schedule of prednisolone in the long-term treatment of early cases of Duchenne dystrophy. Neuromuscular disorders : NMD 12 Suppl 1, 74, doi:10.1016/S0960-8966(02)00097-4 (2002).

61 Gorospe, J., Tharp, M., Demitsu, T. \& Hoffman, E. Dystrophin-deficient myofibers are vulnerable to mast cell granule-induced necrosis. Neuromuscular disorders : NMD 4, 325-333, doi:10.1016/0960-8966(94)90068-X (1994).

62 Zatz, M., Betti, R. \& Frota-Pessoa, O. Treatment of Duchenne muscular dystrophy with growth hormone inhibitors. American journal of medical genetics 24, 549566, doi:10.1002/ajmg.1320240322 (1986).

63 Merlini, L. et al. Early corticosteroid treatment in 4 Duchenne muscular dystrophy patients: 14-year follow-up. Muscle \& nerve 45, 796-802, doi:10.1002/mus.23272 (2012).

64 Matsuo, M., Takeshima, Y., Yagi, M., Ishibashi, K. \& Wada, H. [Treatment of Duchenne muscular dystrophy with gentamicin]. No to hattatsu. Brain and development 36, 125-129 (2004).

65 Welch, E. et al. PTC124 targets genetic disorders caused by nonsense mutations. Nature 447, 87-91, doi:10.1038/nature05756 (2007).

66 Finkel, R. Read-through strategies for suppression of nonsense mutations in Duchenne/ Becker muscular dystrophy: aminoglycosides and ataluren (PTC124). Journal of child neurology 25, 1158-1164, doi:10.1177/0883073810371129 (2010). 
67 McElroy, S. et al. A Lack of Premature Termination Codon Read-Through Efficacy of PTC124 (Ataluren) in a Diverse Array of Reporter Assays. PLoS biology 11, doi:10.1371/journal.pbio.1001593 (2013).

68 Iezzi, S., Cossu, G., Nervi, C., Sartorelli, V. \& Puri, P. Stage-specific modulation of skeletal myogenesis by inhibitors of nuclear deacetylases. Proceedings of the National Academy of Sciences of the United States of America 99, 7757-7762, doi:10.1073/pnas.112218599 (2002).

69 Minetti, G. et al. Functional and morphological recovery of dystrophic muscles in mice treated with deacetylase inhibitors. Nature medicine 12, 1147-1150, doi:10.1038/nm1479 (2006).

70 Consalvi, S. et al. Histone deacetylase inhibitors in the treatment of muscular dystrophies: epigenetic drugs for genetic diseases. Molecular medicine (Cambridge, Mass.) 17, 457-465, doi:10.2119/molmed.2011.00049 (2011).

71 Konieczny, P., Swiderski, K. \& Chamberlain, J. Gene and cell-mediated therapies for muscular dystrophy. Muscle \& nerve 47, 649-663, doi:10.1002/mus.23738 (2013).

72 Mendell, J. et al. Dystrophin immunity in Duchenne's muscular dystrophy. The New England journal of medicine 363, 1429-1437, doi:10.1056/NEJMoa1000228 (2010).

73 Chamberlain, J. S. Dystrophin levels required for generic correction of Duchenne muscular dystrophy. BAM-PADOVA- 7, 251-256 (1997). 
74 Harper, S. et al. Modular flexibility of dystrophin: implications for gene therapy of Duchenne muscular dystrophy. Nature medicine 8, 253-261, doi:10.1038/nm0302-253 (2002).

75 Aartsma-Rus, A. et al. Antisense-induced multiexon skipping for Duchenne muscular dystrophy makes more sense. American journal of human genetics 74, 83-92, doi:10.1086/381039 (2004).

76 Goyenvalle, A. et al. Rescue of dystrophic muscle through U7 snRNA-mediated exon skipping. Science (New York, N.Y.) 306, 1796-1799, doi:10.1126/science.1104297 (2004).

77 Heemskerk, H. et al. Preclinical PK and PD studies on 2'-0-methylphosphorothioate RNA antisense oligonucleotides in the mdx mouse model. Molecular therapy : the journal of the American Society of Gene Therapy 18, 12101217, doi:10.1038/mt.2010.72 (2010).

78 Brutsaert, D. Cardiac endothelial-myocardial signaling: its role in cardiac growth, contractile performance, and rhythmicity. Physiological reviews 83, 59-115, doi:10.1152/physrev.00017.2002 (2003).

79 Goyenvalle, A. et al. Rescue of severely affected dystrophin/utrophin-deficient mice through scAAV-U7snRNA-mediated exon skipping. Human molecular genetics 21, 2559-2571, doi:10.1093/hmg/dds082 (2012).

80 Dellavalle, A. et al. Pericytes of human skeletal muscle are myogenic precursors distinct from satellite cells. Nature cell biology 9, 255-267, doi:10.1038/ncb1542 (2007). 
81 Partridge, T. Myoblast transplantation. Neuromuscular disorders : NMD 12 Suppl 1, 6, doi:10.1016/S0960-8966(02)00076-7 (2002).

82 Ferrari, G. et al. Muscle regeneration by bone marrow-derived myogenic progenitors. Science (New York, N.Y.) 279, 1528-1530, doi:10.1126/science.279.5356.1528 (1998).

83 LaBarge, M. \& Blau, H. Biological progression from adult bone marrow to mononucleate muscle stem cell to multinucleate muscle fiber in response to injury. Cell 111, 589-601 (2002).

84 Asakura, A., Seale, P., Girgis-Gabardo, A. \& Rudnicki, M. Myogenic specification of side population cells in skeletal muscle. The Journal of cell biology 159, 123-134, doi:10.1083/jcb.200202092 (2002).

85 Schienda, J. et al. Somitic origin of limb muscle satellite and side population cells. Proceedings of the National Academy of Sciences of the United States of America 103, 945-950, doi:10.1073/pnas.0510164103 (2006).

86 De Angelis, L. et al. Skeletal myogenic progenitors originating from embryonic dorsal aorta coexpress endothelial and myogenic markers and contribute to postnatal muscle growth and regeneration. The Journal of cell biology 147, 869878, doi:10.1083/jcb.147.4.869 (1999).

87 Minasi, M. et al. The meso-angioblast: a multipotent, self-renewing cell that originates from the dorsal aorta and differentiates into most mesodermal tissues. Development (Cambridge, England) 129, 2773-2783 (2002). 
88 Sampaolesi, M. et al. Cell therapy of alpha-sarcoglycan null dystrophic mice through intra-arterial delivery of mesoangioblasts. Science (New York, N.Y.) 301, 487-492, doi:10.1126/science.1082254 (2003).

89 Sampaolesi, M. et al. Mesoangioblast stem cells ameliorate muscle function in dystrophic dogs. Nature 444, 574-579, doi:10.1038/nature05282 (2006).

90 Crisan, M. et al. A perivascular origin for mesenchymal stem cells in multiple human organs. CELL STEM CELL 3, 301-313, doi:10.1016/j.stem.2008.07.003 (2008).

91 Bianco, P., Robey, P. \& Simmons, P. Mesenchymal stem cells: revisiting history, concepts, and assays. Cell stem cell 2, 313-319, doi:10.1016/j.stem.2008.03.002 (2008).

92 Tavassoli, M. \& Crosby, W. Transplantation of marrow to extramedullary sites. Science (New York, N.Y.) 161, 54-56, doi:10.1126/science.161.3836.54 (1968).

93 Friedenstein, A., Piatetzky-Shapiro, I. \& Petrakova, K. Osteogenesis in transplants of bone marrow cells. Journal of embryology and experimental morphology 16, $381-390$ (1966).

94 Owen, M. \& Friedenstein, A. Stromal stem cells: marrow-derived osteogenic precursors. Ciba Foundation symposium 136, $42-60$ (1988).

95 Pittenger, M. et al. Multilineage potential of adult human mesenchymal stem cells. Science (New York, N.Y.) 284, 143-147, doi:10.1126/science.284.5411.143 (1999). 
96 Caplan, A. Mesenchymal stem cells. Journal of orthopaedic research : official publication of the Orthopaedic Research Society 9, 641-650, doi:10.1002/jor.1100090504 (1991).

97 Salem, H. \& Thiemermann, C. Mesenchymal stromal cells: current understanding and clinical status. Stem cells (Dayton, Ohio) 28, 585-596, doi:10.1002/stem.269 (2010).

98 Prockop, D. Marrow stromal cells as stem cells for nonhematopoietic tissues. Science (New York, N.Y.) 276, 71-74, doi:10.1126/science.276.5309.71 (1997).

99 Haynesworth, S., Goshima, J., Goldberg, V. \& Caplan, A. Characterization of cells with osteogenic potential from human marrow. Bone 13, 81-88, doi:10.1016/8756-3282(92)90364-3 (1992).

100 Nombela-Arrieta, C., Ritz, J. \& Silberstein, L. The elusive nature and function of mesenchymal stem cells. Nature reviews. Molecular cell biology 12, 126-131, doi:10.1038/nrm3049 (2011).

101 da Silva Meirelles, L., Chagastelles, P. \& Nardi, N. Mesenchymal stem cells reside in virtually all post-natal organs and tissues. Journal of cell science 119, 22042213, doi:10.1242/jcs.02932 (2006).

102 Bianco, P., Kuznetsov, S., Riminucci, M. \& Gehron Robey, P. Postnatal skeletal stem cells. Methods in enzymology 419, 117-148, doi:10.1016/S00766879(06)19006-0 (2006). 
103 Alvarez-Dolado, M. et al. Fusion of bone-marrow-derived cells with Purkinje neurons, cardiomyocytes and hepatocytes. Nature 425, 968-973, doi:10.1038/nature02069 (2003).

104 Petersen, B. et al. Bone marrow as a potential source of hepatic oval cells. Science (New York, N.Y.) 284, 1168-1170, doi:10.1126/science.284.5417.1168 (1999).

105 Blau, H., Chiu, C. \& Webster, C. Cytoplasmic activation of human nuclear genes in stable heterocaryons. Cell 32, 1171-1180, doi:10.1016/0092-8674(83)90300-8 (1983).

106 Wakitani, S., Saito, T. \& Caplan, A. Myogenic cells derived from rat bone marrow mesenchymal stem cells exposed to 5-azacytidine. Muscle \& nerve 18, 14171426, doi:10.1002/mus.880181212 (1995).

107 Kocaefe, C., Balci, D., Hayta, B. \& Can, A. Reprogramming of human umbilical cord stromal mesenchymal stem cells for myogenic differentiation and muscle repair. Stem cell reviews 6, 512-522, doi:10.1007/s12015-010-9177-7 (2010).

108 Ferrari, G., Stornaiuolo, A. \& Mavilio, F. Failure to correct murine muscular dystrophy. Nature 411, 1014-1015, doi:10.1038/35082631 (2001).

109 Dellavalle, A. et al. Pericytes resident in postnatal skeletal muscle differentiate into muscle fibres and generate satellite cells. Nature communications 2, 499, doi:10.1038/ncomms1508 (2011).

110 Sacchetti, B. et al. Self-renewing osteoprogenitors in bone marrow sinusoids can organize a hematopoietic microenvironment. Cell 131, 324-336, doi:10.1016/j.cell.2007.08.025 (2007). 
111 Caplan, A. All MSCs are pericytes? Cell stem cell 3, 229-230, doi:10.1016/j.stem.2008.08.008 (2008).

112 Caplan, A. \& Dennis, J. Mesenchymal stem cells as trophic mediators. Journal of cellular biochemistry 98, 1076-1084, doi:10.1002/jcb.20886 (2006).

113 Le Blanc, K., Tammik, L., Sundberg, B., Haynesworth, S. \& Ringdén, O. Mesenchymal stem cells inhibit and stimulate mixed lymphocyte cultures and mitogenic responses independently of the major histocompatibility complex. Scandinavian journal of immunology 57, 11-20, doi:10.1046/j.13653083.2003.01176.x (2003).

114 Bartholomew, A. et al. Mesenchymal stem cells suppress lymphocyte proliferation in vitro and prolong skin graft survival in vivo. Experimental hematology 30, 42-48, doi:10.1016/S0301-472X(01)00769-X (2002).

115 Lazarus, H. et al. Cotransplantation of HLA-identical sibling culture-expanded mesenchymal stem cells and hematopoietic stem cells in hematologic malignancy patients. Biology of blood and marrow transplantation : journal of the American Society for Blood and Marrow Transplantation 11, 389-398, doi:10.1016/j.bbmt.2005.02.001 (2005).

116 Le Blanc, K. et al. Mesenchymal stem cells for treatment of steroid-resistant, severe, acute graft-versus-host disease: a phase II study. Lancet 371, 1579-1586, doi:10.1016/S0140-6736(08)60690-X (2008). 
117 English, K., French, A. \& Wood, K. Mesenchymal stromal cells: facilitators of successful transplantation? Cell stem cell 7, 431-442, doi:10.1016/j.stem.2010.09.009 (2010).

118 Tonlorenzi, R., Dellavalle, A., Schnapp, E., Cossu, G. \& Sampaolesi, M. Isolation and characterization of mesoangioblasts from mouse, dog, and human tissues. Current protocols in stem cell biology Chapter 2, doi:10.1002/9780470151808.sc02b01s3 (2007).

119 English, K., Tonlorenzi, R., Cossu, G. \& Wood, K. Mesoangioblasts suppress T cell proliferation through IDO and PGE-2-dependent pathways. Stem cells and development 22, 512-523, doi:10.1089/scd.2012.0386 (2013).

120 Roobrouck, V. et al. Differentiation potential of human postnatal mesenchymal stem cells, mesoangioblasts, and multipotent adult progenitor cells reflected in their transcriptome and partially influenced by the culture conditions. Stem cells (Dayton, Ohio) 29, 871-882, doi:10.1002/stem.633 (2011).

121 Secco, M. et al. Multipotent stem cells from umbilical cord: cord is richer than blood! Stem cells (Dayton, Ohio) 26, 146-150, doi:10.1634/stemcells.2007-0381 (2008).

122 Meng, X. et al. Endometrial regenerative cells: a novel stem cell population. Journal of translational medicine 5, 57, doi:10.1186/1479-5876-5-57 (2007).

123 Bueno, D., Kerkis, I. \& Costa..., A. New source of muscle-derived stem cells with potential for alveolar bone reconstruction in cleft lip and/or palate patients. ... Engineering Part A (2008). 
124 Buckingham, M., Bajard, L. \& Chang..., T. The formation of skeletal muscle: from somite to limb. Journal of ..., doi:10.1046/j.1469-7580.2003.00139.x (2003).

125 McLoon, L., Thorstenson, K., Solomon, A. \& Lewis, M. Myogenic precursor cells in craniofacial muscles. Oral diseases 13, 134-140, doi:10.1111/j.16010825.2006.01353.x (2007).

126 Tajbakhsh, S. \& Buckingham, M. The birth of muscle progenitor cells in the mouse: spatiotemporal considerations. Current topics in developmental biology 48, 225-268 (2000).

127 Birchmeier, C. \& Brohmann, H. Genes that control the development of migrating muscle precursor cells. Current opinion in cell biology 12, 725-730 (2000).

128 Covas, D., Siufi, J., Silva, A. \& Orellana, M. Isolation and culture of umbilical vein mesenchymal stem cells. Brazilian journal of medical and biological research = Revista brasileira de pesquisas médicas e biológicas / Sociedade Brasileira de Biofísica ... [et al.] 36, 1179-1183 (2003).

129 Pisani, D. et al. Isolation of a highly myogenic CD34-negative subset of human skeletal muscle cells free of adipogenic potential. Stem cells (Dayton, Ohio) 28, 753-764, doi:10.1002/stem.317 (2010).

130 Conconi, M. et al. CD105(+) cells from Wharton's jelly show in vitro and in vivo myogenic differentiative potential. International journal of molecular medicine 18, 1089-1096 (2006). 
131 Dominici, M. et al. Minimal criteria for defining multipotent mesenchymal stromal cells. The International Society for Cellular Therapy position statement. Cytotherapy 8, 315-317, doi:10.1080/14653240600855905 (2006).

132 Barry, F., Boynton, R., Murphy, M., Haynesworth, S. \& Zaia, J. The SH-3 and SH-4 antibodies recognize distinct epitopes on CD73 from human mesenchymal stem cells. Biochemical and biophysical research communications 289, 519-524, doi:10.1006/bbrc.2001.6013 (2001).

133 Barry, F., Boynton, R., Haynesworth, S., Murphy, J. \& Zaia, J. The monoclonal antibody SH-2, raised against human mesenchymal stem cells, recognizes an epitope on endoglin (CD105). Biochemical and biophysical research communications 265, 134-139, doi:10.1006/bbrc.1999.1620 (1999).

134 Bianco, P. et al. The meaning, the sense and the significance: translating the science of mesenchymal stem cells into medicine. Nature medicine 19, 35-42, doi:10.1038/nm.3028 (2013).

135 Uezumi, A., Fukada, S.-i., Yamamoto, N., Takeda, S. i. \& Tsuchida, K. Mesenchymal progenitors distinct from satellite cells contribute to ectopic fat cell formation in skeletal muscle. Nature cell biology 12, 143-152, doi:10.1038/ncb2014 (2010).

136 Pavlath, G. \& Gussoni, E. Human myoblasts and muscle-derived SP cells. Methods in molecular medicine 107, 97-110 (2005).

137 Battula, V. et al. Isolation of functionally distinct mesenchymal stem cell subsets using antibodies against CD56, CD271, and mesenchymal stem cell antigen-1. Haematologica 94, 173-184, doi:10.3324/haematol.13740 (2009). 
138 Zaruba, M.-M. \& Franz, W.-M. Role of the SDF-1-CXCR4 axis in stem cell-based therapies for ischemic cardiomyopathy. Expert opinion on biological therapy 10, 321-335, doi:10.1517/14712590903460286 (2010).

139 Aiuti, A., Webb, I., Bleul, C., Springer, T. \& Gutierrez-Ramos, J. The chemokine SDF-1 is a chemoattractant for human CD34+ hematopoietic progenitor cells and provides a new mechanism to explain the mobilization of CD34+ progenitors to peripheral blood. The Journal of experimental medicine 185, 111-120, doi:10.1084/jem.185.1.111 (1997).

140 Cencioni, C., Capogrossi, M. \& Napolitano, M. The SDF-1/CXCR4 axis in stem cell preconditioning. Cardiovascular research 94, 400-407, doi:10.1093/cvr/cvs132 (2012).

141 Sherwood, R. et al. Isolation of adult mouse myogenic progenitors: functional heterogeneity of cells within and engrafting skeletal muscle. Cell 119, 543-554, doi:10.1016/j.cell.2004.10.021 (2004).

142 Cerletti, M. et al. Highly efficient, functional engraftment of skeletal muscle stem cells in dystrophic muscles. Cell 134, 37-47, doi:10.1016/j.cell.2008.05.049 (2008).

143 King, K., Smith, S., Chapman, M. \& Sacks, G. Detailed analysis of peripheral blood natural killer (NK) cells in women with recurrent miscarriage. Human reproduction (Oxford, England) 25, 52-58, doi:10.1093/humrep/dep349 (2010). 
144 Bianco, P., Riminucci, M., Gronthos, S. \& Robey, P. Bone marrow stromal stem cells: nature, biology, and potential applications. Stem cells (Dayton, Ohio) 19, 180-192, doi:10.1634/stemcells.19-3-180 (2001).

145 Shi, S. \& Gronthos, S. Perivascular niche of postnatal mesenchymal stem cells in human bone marrow and dental pulp. Journal of bone and mineral research : the official journal of the American Society for Bone and Mineral Research 18, 696704, doi:10.1359/jbmr.2003.18.4.696 (2003).

146 Alcoser, S. et al. Real-time PCR-based assay to quantify the relative amount of human and mouse tissue present in tumor xenografts. BMC biotechnology 11, 124, doi:10.1186/1472-6750-11-124 (2011).

147 Song, P. et al. Human genome-specific real-time PCR method for sensitive detection and reproducible quantitation of human cells in mice. Stem cell reviews 8, 1155-1162, doi:10.1007/s12015-012-9406-3 (2012).

148 Crisan, M. et al. A perivascular origin for mesenchymal stem cells in multiple human organs. Cell stem cell 3, 301-313, doi:10.1016/j.stem.2008.07.003 (2008).

149 Orciani, M. et al. Potential role of culture mediums for successful isolation and neuronal differentiation of amniotic fluid stem cells. International journal of immunopathology and pharmacology 21, 595-602 (2008).

150 Hagmann, S. et al. Different culture media affect growth characteristics, surface marker distribution and chondrogenic differentiation of human bone marrowderived mesenchymal stromal cells. BMC musculoskeletal disorders 14, 223, doi:10.1186/1471-2474-14-223 (2013). 
151 Vaquette, C., Ivanovski, S., Hamlet, S. \& Hutmacher, D. Effect of culture conditions and calcium phosphate coating on ectopic bone formation. Biomaterials $\mathbf{3 4}$, 5538-5551, doi:10.1016/j.biomaterials.2013.03.088 (2013).

152 Birbrair, A. et al. Role of Pericytes in Skeletal Muscle Regeneration and Fat Accumulation. Stem cells and development, doi:10.1089/scd.2012.0647 (2013).

153 Corselli, M. et al. Identification of perivascular mesenchymal stromal/stem cells by flow cytometry. Cytometry. Part A : the journal of the International Society for Analytical Cytology, doi:10.1002/cyto.a.22313 (2013).

154 Enwere, E. et al. TWEAK and cIAP1 Regulate Myoblast Fusion Through the Noncanonical NF- $\kappa$ B Signaling Pathway. Science signaling 5, doi:10.1126/scisignal.2003086 (2012).

155 Cerletti, M., Jang, Y., Finley, L., Haigis, M. \& Wagers, A. Short-term calorie restriction enhances skeletal muscle stem cell function. Cell stem cell 10, 515519, doi:10.1016/j.stem.2012.04.002 (2012).

156 Conboy, M., Cerletti, M., Wagers, A. \& Conboy, I. Immuno-analysis and FACS sorting of adult muscle fiber-associated stem/precursor cells. Methods in molecular biology (Clifton, N.J.) 621, 165-173, doi:10.1007/978-1-60761-0632_11 (2010).

157 Gilbert, P. et al. Substrate elasticity regulates skeletal muscle stem cell selfrenewal in culture. Science (New York, N.Y.) 329, 1078-1081, doi:10.1126/science.1191035 (2010). 
158 Cerletti, M. et al. Melanoma cell adhesion molecule is a novel marker for human fetal myogenic cells and affects myoblast fusion. Journal of cell science 119, 3117 3127, doi:10.1242/jcs.03056 (2006).

159 Vallese, D. et al. The Rag2(-)Il2rb(-)Dmd(-) mouse: a novel dystrophic and immunodeficient model to assess innovating therapeutic strategies for muscular dystrophies. Molecular therapy : the journal of the American Society of Gene Therapy, doi:10.1038/mt.2013.186 (2013).

160 Lavasani, M. et al. Muscle-derived stem/progenitor cell dysfunction limits healthspan and lifespan in a murine progeria model. Nature communications $\mathbf{3}$, 608, doi:10.1038/ncomms1611 (2012). 


\section{Biografia}

Marcos Costa Valadares é Bacharel em Ciências Biológicas pela Universidade de São Paulo (2007). Atualmente é aluno de pós- graduação (Doutorado Direto) do Departamento de Genética e Biologia Evolutiva do Instituto de Biociências da Universidade de São Paulo (2013). Esta tese é apresentada para a obtenção de Titulo de Doutor em Ciências, na área de Biologia/Genética

1- CE Ambrósio, MC Valadares, E Zucconi, R Cabral, PL Pearson, TP Gaiad, M Ringo, a Golden Retriever Muscular Dystrophy (GRMD) dog with absent dystrophin but normal strength. Neuromuscular Disorders 18 (11), 892

2- M Mitne-Neto, F Kok, C Beetz, A Pessoa, C Bueno, Z Graciani, M Martyn, CBM... A multiexonic SPG4 duplication underlies sex-dependent penetrance of hereditary spastic paraplegia in a large Brazilian pedigree. European Journal of Human Genetics 15 (12), 12761279

3- E Zucconi, MC Valadares, NM Vieira, CR Bueno, M Secco, T Jazedje, HC Almeida... Ringo: discordance between the molecular and clinical manifestation in a golden retriever muscular dystrophy dog. Neuromuscular Disorders 20 (1), 64-70

4- NM Vieira, M Valadares, E Zucconi, M Secco, CR Bueno, V Brandalise, A Assoni... Human Adipose-Derived Mesenchymal Stromal cells injected systemically into GRMD dogs without immunosuppression are able to reach the host muscle and express human dystrophin. Cell Transplantation

5- C Ambrosio, E Zucconi, D Martins, C Vanucchi, M Perez, N Vieira, M Valadares... GP 1.16 Extreme clinical variability in GRMD: From neonatal death to asymptomatic carriers. Neuromuscular Disorders 17 (9), 776-776

6- M Secco, NM Vieira, T Jazedje, CB Júnior, M Valadares, OK Okamoto, M Zatz. P3. 28 Do factors released from dystrophic muscle enhance myogenic differentiation of mesenchymal stem cells from human umbilical cord tissue? Neuromuscular Disorders 20 (9), 649-649

7- M Zatz, E Zucconi, M Valadares, T Jazedje. Phenotypes in golden retriever.. Neuromuscular disorders: NMD 20 (1), 71

8- E Zucconi, T Jazedje, MC Valadares, M Zatz. Comments to the paper by Ambrósio CE, Fadel L, Gaiad TP, Martins DS, et al.[Identification of three distinguishable phenotypes in golden retriever muscular dystrophy (Genet. Mol. Res. 2009 Apr 7; 8 (2): 389-396)]. Genetics 
and Molecular Research 8 (3), 818- 821

9- M Zatz, NM Vieira, M Valadares, M Secco, E Zucconi, CJR Bueno, V Brandalise ...O. 1 Preclinical studies with human adult mesenchymal stem- cells: What have we learned?

Neuromuscular Disorders 21 (9), 640-640 